\title{
The Constitution in the Supreme Court: The Powers of the Federal Courts, 1801-1835
}

\author{
David P. Currie†
}

In an earlier article I attempted to examine critically the constitutional work of the Supreme Court in its first twelve years. ${ }^{1}$ This article begins to apply the same technique to the period of Chief Justice John Marshall.

When Marshall was appointed in 1801 the slate was by no means clean; many of our lasting principles of constitutional jurisprudence had been established by his predecessors. This had been done, however, in a rather tentative and unobtrusive manner, through suggestions in the seriatim opinions of individual Justices and through conclusory statements or even silences in brief per curiam announcements. Moreover, the Court had resolved remarkably few important substantive constitutional questions. It had essentially set the stage for John Marshall.

Marshall's long tenure divides naturally into three periods. From 1801 until 1810, notwithstanding the explosive decision in Marbury v. Madison, ${ }^{2}$ the Court was if anything less active in the constitutional field than it had been before Marshall. Only a dozen or so cases with constitutional implications were decided; most of them concerned relatively minor matters of federal jurisdiction; most of the opinions were brief and unambitious. Moreover, the cast of characters was undergoing rather constant change. Of Marshall's five original colleagues, William Cushing, William Paterson, Samuel Chase, and Alfred Moore had all been replaced by $1811 .{ }^{3}$

From the decision in Fletcher v. Peck ${ }^{4}$ in 1810 until about 1825 , in contrast, the list of constitutional cases contains a succes-

$\dagger$ Harry N. Wyatt Professor of Law, University of Chicago. I should like to thank my colleagues Frank Easterbrook, Stanton Krauss, Philip B. Kurland, Phil C. Neal, Raymond Solomon, and James B. White for their helpful comments and encouragement, and Locke Bowman and Paul Strella, J.D. The University of Chicago 1982, for their valuable research assistance.

${ }^{1}$ Currie, The Constitution in the Supreme Court: 1789-1801, 48 U. CHI. L. REv. 819 (1981).

25 U.S. (1 Cranch) 137 (1803).

s Only Bushrod Washington and Marshall himself remained. See infra note 26.

- 10 U.S. (6 Cranch) 87 (1810). 
sion of landmarks: Martin v. Hunter's Lessee, ${ }^{\mathrm{B}} \mathrm{McCulloch} v$. Maryland, ${ }^{8}$ Trustees of Dartmouth College v. Woodward, ${ }^{7}$ Cohens $v$. Virginia, ${ }^{8}$ Gibbons v. Ogden, ${ }^{9}$ Osborn v. Bank of the United States, ${ }^{10}$ to name only a few. This was a time of vigorous affirmation of national authority and of vigorous enforcement of constitutional limitations on the states; a time of extensive opinions in the grand style we have come to associate with Marshall; a time, moreover, of remarkable stability and official unanimity. For most of the fifteen crucial years between 1810 and 1825, the Court was comprised of the same seven Justices: Marshall, Bushrod Washington, William Johnson, Brockholst Livingston, Thomas Todd, Joseph Story, and Gabriel Duvall.11 Though all but Marshall and Washington had been appointed by the anti-Federalist Presidents Thomas Jefferson and James Madison, ${ }^{12}$ the rarity of recorded dissent during this period was so great as to be almost incredible by modern standards. Some part of the apparent unanimity was doubtless due to Marshall's policy of keeping disagreements within the Court, ${ }^{13}$ yet the opinions of William Johnson, his most independent colleague, suggest that all seven Justices shared a common view of the Constitution down to many matters of mere detail.

From the mid-1820's to Marshall's death in 1835, the Court continued to lay down decisions of lasting significance: Ogden $v$.

- 14 U.S. (1 Wheat.) 304 (1816).

- 17 U.S. (4 Wheat.) 316 (1819).

717 U.S. (4 Wheat.) 518 (1819).

- 19 U.S. (6 Wheat.) 264 (1821).

- 22 U.S. (9 Wheat.) 1 (1824).

1022 U.S. (9 Wheat.) 738 (1824).

31 See infra note 26 . The first six positions had been authorized by the Judiciary Act of 1789 , ch. $20, \S 1,1$ Stat. 73,73 (current version at 28 U.S.C. $\S 1$ (1976)). The seventh position had been authorized by the Act of Feb. 24, 1807, ch. 16, $\$$, 2 Stat. 420, 421 (current version at 28 U.S.C. $\$ 1$ (1976)).

One of Marshall's biographers insisted, without citation of authority, that the correct spelling of Justice Duvall's name was "Duval." 4 A. Bevermoge, LIFg OF JoHN MArshall 60 n.1 (1919). However, Cranch, Wheaton, and Peters, Supreme Court reporters while the Justice was on the bench, all spelled his name "Duvall." Irving Dilliard, who traced the family history, concluded that the original "DuVal" or "Duval" of the Justice's immigrant greatgrandfather had become "Duvall" by the time the future Justice was born. Dilliard, Gabriel Duvall, in 1 Justices of tHe Supreme Court 419-21 (L. Friedman \& F. Israel eds. 1969).

12 See infra note 26.

13 See D. Morgan, Justice William Johnson: The First Dissenter 168-86 (1954), and especially Johnson's letter to Thomas Jefferson (Dec. 10, 1822), quoted in id. at 182 ("[D]uring the rest of the session I heard nothing but lectures on the indecency of judges cutting each other . . . . At length $I$ found that I must either submit to circumstances or become such a cypher in our consultations as to effect no good at all . . . ."). See also Roper, Judicial Unanimity and the Marshall Court: A Road to Reappraisal, 9 AM. J.L. HIST. 118 (1965). 
Saunders, ${ }^{14}$ Brown v. Maryland, ${ }^{16}$ Craig v. Missouri, ${ }^{16}$ Worcester v. Georgia ${ }^{17}$ Barron v. Baltimore. ${ }^{18}$ Yet this period can be described as one of consolidation and transition. The Court increasingly refused to extend the limits it had found imposed on the states, and it increasingly divided as Marshall's longtime colleagues were gradually replaced by men of a new generation: Smith Thompson, Robert Trimble, John McLean, Henry Baldwin.19

Notwithstanding these divisions, the Marshall period as a whole has a coherent character of its own. The Court under Marshall had a unique opportunity to put meat on the largely bare bones of the Constitution, and a great deal of what it put there has remained. One important factor in this durability was that the Court spoke with a remarkably uniform voice over a very long period of time. Only sixteen men sat on the Court during the entire Marshall period. Of the seven Justices who sat together between 1810 and 1823, four continued to sit until $1834, ;^{20}$ a majority of the Court thus remained intact for twenty-three years. Even in the last years, moreover, when dissents became somewhat more frequent, the voice with which the Court spoke was almost exclusively that of John Marshall. Not only does there seem to have been but one constitutional case in thirty-five years in which the Chief Justice recorded a dissent; ${ }^{21}$ there were only a handful in which he did not deliver the Court's opinion. Even the previously irrepressible Chase $^{22}$ was never heard from again after $1801 .{ }^{23}$ Of most of Marshall's brethren, however great their backstage influence on the course of constitutional decision, ${ }^{24}$ we know virtually nothing from

1625 U.S. (12 Wheat.) 213 (1827).

${ }^{25} 25$ U.S. (12 Wheat.) 419 (1827).

1629 U.S. (4 Pet.) 410 (1830).

1731 U.S. (6 Pet.) 515 (1832).

1832 U.S. (7 Pet.) 243 (1833).

19 McLean replaced Trimble, who died after two years on the bench. See infra note 26. James Wayne sat with Marshall during the latter's last Term, but no constitutional cases were then decided.

20 Marshall, Johnson, Duvall, and Story. See id.

21 Ogden v. Sauders, 25 U.S. (12 Wheat.) 213, 332 (1827). But see infra note 353 and accompanying text (discussing Houston v. Moore).

22 See generally Currie, supra note 1 , at 854-75, 878-81, 885.

${ }^{23}$ Chase did, however, make additional headlines when the Republicans unsuccessfully impeached him in 1805. See 1 C. WarRen, The Supreme Court In UnIted States History 269-315 (rev, ed. 1926).

24 That Marshall delivered the Court's opinion does not prove that he wrote it, or even that he agreed with it. See G. Hasknns \& H. Johnson, 2 History or the Supreme Court of THE UNITED STATEs 384-86 (1981) (citing a case in which Marshall said he had been instructed to present the Court's reasons though he did not agree with them); Letter from Justice Johnson to Thomas Jefferson (Dec. 10, 1822) (complaining that it was Marshall's 
the opinions beyond their concurrence in the results. ${ }^{25}$ In stark contrast to my examination of the period before 1801, the present study is essentially of one man. ${ }^{20}$

Although my focus is chronological, my chief interest is in the Marshall period as a whole, and some grouping of cases by subject matter is necessary to avoid a totally disjointed presentation. I have therefore departed from a strictly chronological discussion. The present article deals with those constitutional decisions of Marshall's time respecting the powers of the federal courts; ${ }^{27}$ the

initial practice to "deliver[] all the opinions in cases in which he sat, even in some instances when contrary to his own judgment and vote"), quoted in D. MorgaN, supra note 13, at 181-82. See also Frankfurter, John Marshall and the Judicial Function, 69 HARv. L. Rev. 217,221 (1955) ("One may be confident in inferring that the novelty of the issues, the close social relations of the Justices, the ample opportunities they had for discussions among themselves, precluded Marshall's pathbreaking opinions from being exclusively solo performances.").

${ }^{25}$ Several of them made important contributions in the circuit courts, but that is material for another study.

28

Justices of the Supreme Court During the Chisf Justiceship of John Marshate

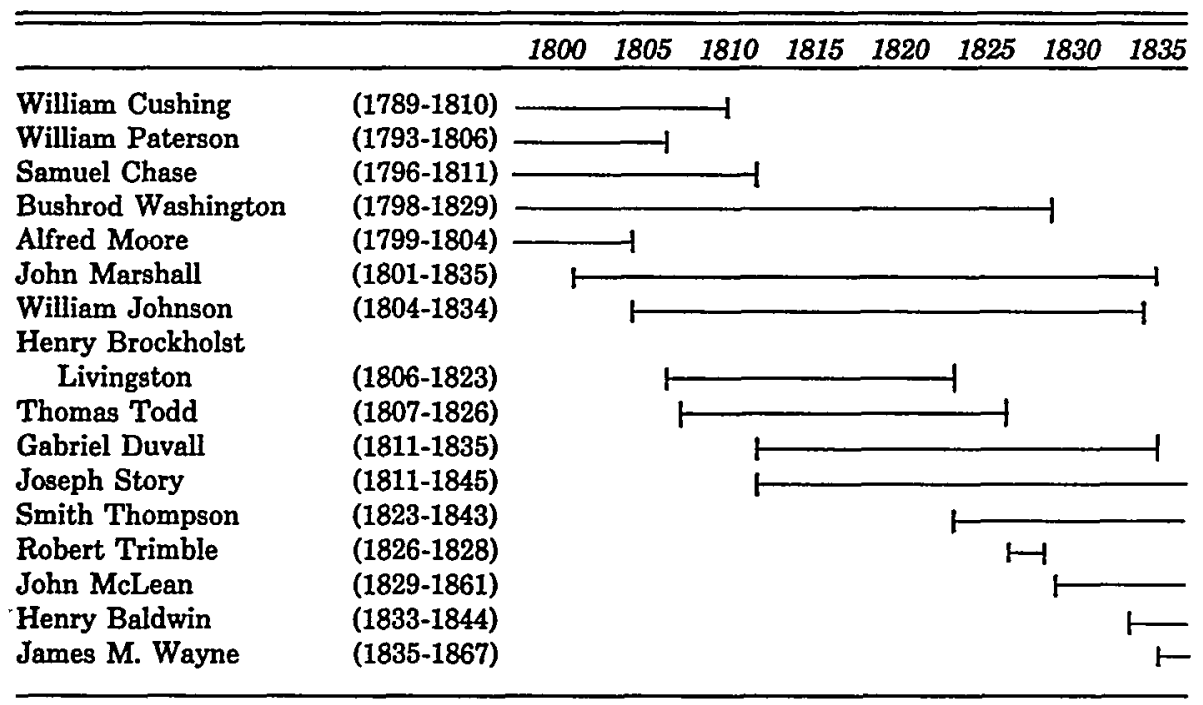

Source: Adapted from G. Gunther, Cases and Materials on Constitutional Law app. A, at A-1 to A-2 (10th ed. 1980).

${ }^{27}$ Before Marshall's appointment to the Court, moreover, there were so few decisions that virtually every encounter with the Constitution told us something significant about the Court's developing approach to constitutional litigation. The relative profusion of cases during the Marshall era makes a comparable effort at completeness one of significantly diminishing returns. Thus I have reduced to brief references a number of decisions that afford little substantive or methodological illumination. 
contemporaneous substantive decisions will be discussed in a subsequent article.

The threshold question of jurisdiction inheres in every controversy. Issues of federal jurisdiction dominated the Court's constitutional docket until $1810^{28}$ and remained a significant part of it throughout Marshall's tenure.

Much of our current understanding of the federal judicial power dates from the Marshall period. Marbury v. Madison ${ }^{29}$ confirmed the practice of judicial review of Acts of Congress and narrowly limited the Supreme Court's original jurisdiction. Martin $v$. Hunter's Lessee ${ }^{30}$ and Cohens $v$. Virginia ${ }^{31}$ affirmed the Court's authority to review state court decisions denying federal rights. Osborn $v$. Bank of the United States ${ }^{32}$ opened the federal courts to suits against state officers and gave a broad interpretation to the power over cases "arising under" federal law. Numerous decisions, nominally interpreting the jurisdictional statutes, continued the process of giving content to the constitutional provisions for diversity and admiralty jurisdiction. Wayman v. Southard ${ }^{3 s}$ affirmed the power of the courts, with statutory authorization, to regulate their own procedures. Parsons v. Bedford ${ }^{34}$ and Bank of Columbia v. Okely ${ }^{35}$ began to interpret the right to a civil jury. American Insurance Co. $v$. Canter ${ }^{36}$ laid the foundation for the doctrine of "legislative" courts and thus for modern quasi-judicial agencies.

These are but the highlights of a rich collection, and most of them have withstood the test of time. It is significant that the Marshall Court took a rather broad view of the federal judicial power. It is also significant that the principal departure of Marshall's successors in this field would be to take a still broader view of federal jurisdiction in diversity ${ }^{37}$ and admiralty ${ }^{38}$ cases.

28 As they had before Marshall's appointment. See Currie, supra note 1, at 822-53.

295 U.S. (1 Cranch) 137 (1803).

so 14 U.S. (1 Wheat.) 304 (1816).

3119 U.S. (6 Wheat.) 264 (1821).

ss 22 U.S. (9 Wheat.) 738 (1824).

ss 23 U.S. (10 Wheat.) 1 (1825).

st 28 U.S. (3 Pet.) 433 (1830).

ss 17 U.S. (4 Wheat.) 235 (1819).

s6 26 U.S. (1 Pet.) 511 (1828).

${ }^{37}$ E.g., Marshall v. Baltimore \& O.R.R., 57 U.S. (16 How.) 314 (1854) (members of corporation deemed citizens of state of incorporation).

ss E.g., The Propeller Genesee Chief v. Fitzhugh, 53 U.S. (12 How.) 443 (1852) (Great Lakes within admiralty jurisdiction). 


\section{Judicial Review; Original and Appellate Jurisdiction}

\section{A. Marbury v. Madison}

It seems entirely appropriate that the very first constitutional decision of the Court under Marshall was the most fundamental of them all. By establishing the power of judicial review, the Marbury opinion paved the way for great controversies to come. It was, moreover, in many respects highly representative of the style of Marshall's major opinions.

The facts are familiar. The commission of the Federalist William Marbury as justice of the peace had been signed and sealed just hours before the Federalists left office, and he asked the Supreme Court for a mandamus directing the new Republican Secretary of State to deliver it. The Court in an 1803 Marshall opinion dismissed for want of jurisdiction. . $^{39}$

En route to that disposition the Court did a number of interesting things. Of interest in respect to the mundane holding that the commission was effective without delivery ${ }^{10}$ was the fact that the Court addressed the issue at all, for it held that it had no jurisdiction." The same can be said of the famous conclusion that mandamus would lie against the Secretary of State, ${ }^{42}$ which has had important implications for the overall doctrine of separation of

30 5 U.S. (1 Cranch) 137, 173, 180 (1803). For the political background of this case, see R. Ellis, The Jefrersonian Crisis: Courts and Politics in the Young Republic 43-45, 58, 64-68 (1971).

40 5 U.S. (1 Cranch) at 155-62.

4Some might call the Court's comments on this issue an advisory opinion, which the Justices eight years earlier had implied they had no power to give. See Letter from Thomas Jefferson to the Justices (July 18, 1793); Letter from the Justices to George Washington (Aug. 8, 1793) [hereinafter cited as Correspondence of the Justices], reprinted in P. BATOR, P. Mishkin, D. Shapiro \& H. Wechsler, Hart \& Wechsler's The Fedrral Courts and The Frderal System 64-66 (2d ed. 1973) [hereinafter cited as Hart \& WechsLer]; J. Thayer, John Marshall 62-63 (P. Kurland ed. 1967) ("Unfortunately, instead of proceeding as courts usually do, the opinion began by passing upon all the points which the denial of its own jurisdiction took from it the right to treat."); Currie, supra note 1, at 828-31. One must be cautious in evaluating early materials by modern standards; Marbury and other Marshall opinions suggest the important question whether attitudes about the propriety of judicial pronouncements going beyond the necessities of the case have remained constant over nearly two centuries. But Jefferson, at least, criticized Marshall for "traveling out of his case." Letter from Thomas Jefferson to Justice Johnson (June 12, 1823), quoted in $1 \mathrm{C}$. WARRBN, supra note 23, at 245. See also 1 C. WARREN, supra note 23, at 249-51 (reporting similar contemporary views). G. GuNTHER, supra note 26 , at $12-13$, raises the further question whether Marshall should have disqualified himself because he was the Secretary of State who had signed and sealed Marbury's commission and because his brother had submitted an evidentiary affidavit.

425 U.S. (1 Cranch) at 162-73. 
powers. ${ }^{43}$ This holding also bears examining for its impact on the undiscussed issue of sovereign immunity, ${ }^{44}$ and it has become fashionable to view Marbury's references to unreviewable "political" actions of the executive ${ }^{45}$ as the foundation of today's political question doctrine. ${ }^{48}$

4s In this connection we find in Marbury a constitutional explanation for the surviving rule limiting mandamus to matters outside the officer's "discretion." The Secretary is an "organ" of the President, in whom article II of the Constitution vests "certain important political powers," $i d$. at 165-66; to interfere with the exercise of executive discretion would thus infringe article II. The conclusion that the Secretary could sometimes be sued, on the other hand, implicitly rejected the argument that every such proceeding would invade the constitutional domain of the executive. Sixty-odd years later the Court was to come close to holding the President could not be sued at all, Mississippi v. Johnson, 71 U.S. (4 Wall.) 475 (1867); Marbury reflects a strikingly different philosophy.

11 In rejecting a state's immunity from suit in Chisholm v. Georgia, 2 U.S. (2 Dall.) 419 (1793), both Justice William Cushing and Chief Justice John Jay had suggested it might not be possible to sue the United States, $i d$. at 469,478 . See Currie, supra note 1, at 836-37. Mandamus against the Secretary would have had the same effect as if the government itself had been named defendant. Marshall's opinion, without mentioning the concept of sovereign immunity, foreshadowed the unsatisfying formalistic distinction the Court was later expressly to draw for this purpose, see infra notes 316-23 and accompanying text (discussing Osborn v. Bank of the United States), between governments and their officers: "If one of the heads of departments commits any illegal act, under color of his office, by which an individual sustains an injury, it cannot be pretended, that his office alone exempts him from being sued in the ordinary mode of proceeding ...." 5 U.S. (1 Cranch) at 170.

Marshall did not pause to investigate whether the British precedents treated mandamus actions as suits against the sovereign, though he did quote Blackstone suggestively. Id. at 165. To support his conclusion on the ground that there were no rights without remedies, as Marshall also did, id. at 163, raises doubt whether he believed the United States itself was immune. But the short answer to any suggestion of sovereign immunity in Marbury should have been that the statute expressly provided for mandamus "to any . . . persons holding office, under the United States." Judiciary Act of 1789, ch. 20, 1 13, 1 Stat. 73, 81 (current version at 28 U.S.C. $\$ 1651$ (1976)). If consent to sue the government was needed, it had been given.

4s See 5 U.S. (1 Cranch) at 165-67, 169-71, especially id. at 170 ("Questions in their nature political, or which are, by the constitution and laws, . . . submitted to the executive, can never be made in this court.").

4s See, e.g., C. Haines, The Role of the Supreme Court in American Government and Politics 1789-1835, at 256 (1946); C. Wright, The Law of Federal Courts 52-56 (3d ed. 1976).

In the hands of proponents like Justice Frankfurter, this doctrine meant the courts would sometimes refuse to give a remedy for an assumed violation of the Constitution. See Baker v. Carr, 369 U.S. 186, 266-330 (1962) (Frankfurter, J., dissenting). It seems, however, that Marshall had nothing of the sort in mind in Marbury. It is true that the "political" discussion appears in a section of the opinion dealing with remedies, following the conclusion that Marbury had a "right" to his commission, 5 U.S. (1 Cranch) at 162, and that at one point Marshall spoke of certain executive "misconduct" for which the individual had no remedy, id. at 164. Elsewhere, however, the opinion appears to equate "political" matters with those in which the executive is entrusted by the Constitution or laws with "discretion," and if an officer has acted within his discretion, he has by definition offended no legal right. See, e.g., id. at 165-66:

By the Constitution of the United States, the president is invested with certain impor- 
On the jurisdictional issue the Court went out of its way to create a constitutional question. Standing alone, the statutory authorization of mandamus "to any . . . persons holding office, under the authority of the United States"17 appeared to authorize the Supreme Court to issue the writ as an original matter, and Marshall took it literally without suggesting there was any reason for doubt. ${ }^{48}$ Significantly, he neglected to quote the entire provision, which read in context strongly suggests that mandamus against officers was to be issued only in an appellate form or ancillary to the exercise of jurisdiction independently existing. ${ }^{99}$ In one of its last pre-Marshall decisions, the Court had performed major surgery on the statutory provision for jurisdiction when "an alien is a party" in order to avoid finding it unconstitutional, ${ }^{50}$ the contrast with Marbury is striking.

The reason the Court declined jurisdiction in Marbury was of course its conclusion that Congress had no power to give the Court original jurisdiction over the controversy. Article III provides that

tant political powers, in the exercise of which he is to use his own discretion .... [W] here the heads of departments are the political or confidential agents of the executive, merely to execute the will of the president, or rather to act in cases in which the executive possesses a constitutional or legal discretion, nothing can be more perfectly clear, than that their acts are only politically examinable.

The sentence before the one quoted supra note 45 reads: "The province of the court is, solely to decide on the rights of individuals, not to inquire how the executive, or executive officers, perform duties at which they have a discretion." 5 U.S. (1 Cranch) at 170. Far from esserting that there might be rights without remedies, Marshall insisted that a government furnishing "no remedy for the violation of a vested legal right" would not deserve to be called one "of laws, and not of men." Id. at 163.

${ }^{47}$ Judiciary Act of 1789 , ch. $20, \S 13,1$ Stat. 73,81 (current version at 28 U.S.C. $\S 1651$ (1976)).

48 5 U.S. (1 Cranch) at 173.

4. The section in question consisted of four sentences. The first three confirmed the Supreme Court's original jurisdiction over cases involving states or foreign diplomats and provided for jury trial in original cases. The final sentence began by noting cases in which the Court has "appellate jurisdiction" and concluded with the quoted reference to the "power" to issue mandamus to federal courts as well as to other officers. Judiciary Act of 1789 , ch. $20, \S 13,1$ Stat. 73, 81 (current version at 28 U.S.C. $\S 1651$ (1976)) (emphasis added). See Van Alstyne, $A$ Critical Guide to Marbury v. Madison, 1969 Duke L.J. 1, 15. See also Corwin, Marbury v. Madison and the Doctrine of Judicial Review, 12 Mich. L. REv. 538, 542 (1914) (emphasis in original):

[I]n Common Law practice, in the light of which $\S 13$ was framed, the writ of mandamus was not, ordinarily at least, an instrument of obtaining jurisdiction by a court, even upon appeal, but like the writs of habeas corpus and injunction, was a remedy available from a court in the exercise of its standing jurisdiction.

so Mossman v. Higginson, 4 U.S. (4 Dall.) 12, 14 (1800) (construing Judiciary Act of 1789 , ch. $20, \S 11,1$ Stat. 73,78 (repealed 1911)). For the current version of the district courts' alienage jurisdiction, see 28 U.S.C. $\$ 1332$ (a) (1976). See also Currie, supra note 1, at 851-52. 
the Supreme Court shall have "original Jurisdiction" in "Cases affecting Ambassadors, other public Ministers and Consuls, and those in which a State shall be Party." Marbury was not such a case, and Article III further provides that in all other cases within the judicial power the Court is to have "appellate Jurisdiction, both as to Law and Fact, with such Exceptions . . . as the Congress shall make." To Marshall the words were clear: "If Congress remains at liberty to give this court appellate jurisdiction, where the constitution has declared their jurisdiction shall be original; and original jurisdiction where the constitution has declared it shall be appellate; the distribution of jurisdiction, made in the constitution, is form without substance."ss

This reasoning is far from obvious. It would not have been idle for the Framers to make a provisional distribution of the Court's jurisdiction pending congressional revision; ${ }^{54}$ that is precisely what they did with respect to the appellate jurisdiction by empowering Congress to make "Exceptions." Indeed, the exceptions clause itself arguably authorized the grant of original mandamus jurisdiction: Congress had made an "exception" to the appellate jurisdiction by providing original jurisdiction instead, ${ }^{55}$ and it had made an "exception" to the otherwise applicable constitutional division. Nor would it have been irrational to read article III as defining a minimum original jurisdiction to prevent Congress from excluding Supreme Court trial of the critical ambassador and state cases. ${ }^{86}$ Marshall himself was to reject the implications of his Marbury reasoning in Cohens $v$. Virginia, ${ }^{57}$ where he declared that Congress

U1 U.S. Const. art. III, § 2, para. 2.

s. Id.

os 5 U.S. (1 Cranch) at 174.

st See Van Alstyne, supra note 49, at 31 n.44.

as See 2 W. Crosskey, Politics and the Constitution in the History of the United States 1041 (1953); Corwin, supra note 49, at 540; Van Alstyne, supra note 49, at 32.

See 2 W. Crosskey, supra note 55, at 1041; Corwin, supra note 49, at 540; Van Alstyne, supra note 49 , at 31 . See also The Federalist No. 81 , at 487 (A. Hamilton) (C. Rossiter ed. 1961), outlining reasons for the grant of original jurisdiction:

All questions in which [public ministers] are concerned, are so directly connected with the pubic peace, that as well for the preservation of this, as out of respect to the sovereignties they represent, it is both expedient and proper, that such questions should be submitted in the first instance to the highest judicatory of the nation . . . . In cases in which a State might happen to be a party, it would ill suit its dignity to be turned over to an inferior tribunal.

But Hamilton also said, without squarely addressing the question of congressional power, that the "original jurisdiction of the Supreme Court would be confined to two classes of causes" and that in all others the Court "would have nothing more than an appellate jurisdiction" with such exceptions as Congress might make. Id.

s7 19 U.S. (6 Wheat.) 264 (1821). See infra notes 287-90 and accompanying text. See 
could grant appellate jurisdiction in cases where the Constitution provided for original. ${ }^{88}$

To dismiss the case, the Court had to conclude that its duty was to follow the Constitution in disregard of a contrary statute, and thus Marshall enunciated the doctrine of judicial review. As interesting as his conclusion is what these passages reveal about Marshall's approach to the writing of opinions.

The issue of judicial review was by no means new. The Privy Council had occasionally applied the ultra vires principle to set aside legislative acts contravening municipal or colonial charters. ${ }^{59}$ State courts had set aside state statutes under constitutions no more explicit about judicial review than the federal. ${ }^{60}$ The Supreme Court itself had measured a state law against a state constitution in Cooper $v$. Telfair ${ }^{81}$ and had struck down another under the supremacy clause ${ }^{62}$ in Ware $v$. Hylton; ${ }^{63}$ in both cases the power of judicial review was expressly affirmed. Even Acts of Congress had been struck down by federal circuit courts, ${ }^{64}$ and the Supreme Court, while purporting to reserve the question of its power to do so, had reviewed the constitutionality of a federal statute in Hylton $v$. United States. ${ }^{65}$ Justice James Iredell had explicitly asserted this power both in Chisholm v. Georgia ${ }^{68}$ and in Calder $v$. $B u l l,{ }^{67}$ and Chase had acknowledged it in Cooper. ${ }^{68}$ In the Conven-

also Bors v. Preston, 111 U.S. 252, 260 (1884).

ss 19 U.S. (6 Wheat.) at $392-403$ (alternative holding). Marshall failed to respond to the argument in Marbury, 5 U.S. (1 Cranch) at 148-49, that the Court had entertained original mandamus petitions before, though without addressing the constitutional issue. See also 2 W. CrosskeY, supra note 55, at 1040. Albert Beveridge said Marshall's argument that section 13 was unconstitutional was "absolutely new, ... the only original idea that Marshall contributed to the entire controversy." $3 \mathrm{~A}$. BEVRRIDGE, supra note 11 , at 128 . The argument that the original jurisdiction could not be expanded, however, was not new. See the Justices' 1790 letter objecting to circuit duty and Justice Chase's 1802 letter on the same subject to Marshall, both cited infra notes 109, 128, and accompanying text.

s9 See J. Goebel, 1 History of the Supreme Court of the Unitrd Statss 50-95 (1971).

so See id. at 96-142; A. McLaughuin, Constitutional History of the United States 312-13 n.34 (1935).

4 U.S. (4 Dall.) 14 (1800).

63 U.S. CoNST. art. VI, para. 2.

os 3 U.S. (3 Dall.) 199 (1796).

os E.g., Hayburn's Case, 2 U.S. (2 Dall.) 409 (1792). See the opinions of the circuit courts for the districts of New York, Pennsylvania, and North Carolina, attached as a footnote in id. at $410-14$ n.(a).

ss 3 U.S. (3 Dall.) 171 (1796).

so 2 U.S. (2 Dall.) 419, 433 (1793) (dissenting opinion).

673 U.S. (3 Dall.) 386, 399 (1798) (separate opinion).

es 4 U.S. (4 Dall.) at 19 (separate opinion). In Hollingsworth v. Virginia, 3 U.S. (3 Dall.) 378 (1798), the Court may actually have invalidated a federal statute, for in deference to the 
tion, moreover, both proponents and opponents of the proposed Council of Revision had recognized that the courts would review the validity of congressional legislation, ${ }^{69}$ and Alexander Hamilton had proclaimed the same doctrine in The Federalist..$^{70}$ Yet though Marshall's principal arguments echoed those of Hamilton, he made no mention of any of this material, writing as if the question had never arisen before. Rare is the judge today who would disdain such support and rely wholly upon the force of his own argument, but his later opinions were to show that Marshall often paid little heed to precedents even when they squarely supported him. ${ }^{71}$

eleventh amendment it dismissed suits against states that came within section 13 of the Judiciary Act as the similarly worded provision of article III had been interpreted in Chisholm. See Currie, supra note 1, at 840-43. On the other hand, the Justices did not refuse to sit on circuit even though they had protested to President Washington that circuit duty was unconstitutional.

69 See, e.g., 1 The Records of the Federal Convention of 1787, at 109 (M. Ferrand rev. ed. 1937) [hereinafter cited as Convention Records] (Rufus King) (Council unnecessary "because the Judges will have the expounding of those Laws when they come before them; and they will no doubt stop the operation of such as shall appear repugnant to the constitution"); $i d$. at 97 (Elbridge Gerry) ("they will have a sufficient check against encroachments on their own department by their exposition of the laws, which involved a power of deciding on their Constitutionality"); 2 id. at 73, 76, 78 (James Wilson, Luther Martin, and George Mason). James Mercer and John Dickinson went on record as disapproving of judicial review, but the latter saw no preferable alternative. Id. at 298-99. See Corwin, supra note 49, at 543 ("That the members of the Convention of 1787 thought the Constitution secured to courts in the United States the right to pass on the validity of acts of Congress under it cannot be reasonably doubted."). Accord, A. Bickel, The LeAST DANgerous Branch 15 (1962); Hart \& Wechsler, supra note 41, at 9. See also 2 J. Elliot, The Debates in the Several State Conventions on the Adoption of the Federal ConstituTION 196 (2d ed. Wash., D.C., 1836) (1st ed. Wash., D.C., 1827-30) [hereinafter cited as ELLIOT's DeBatzs] (Oliver Ellsworth); 3 id. at 553 (John Marshall).

${ }^{70}$ If it be said that the legislative body are themselves the constitutional judges of their own powers, ... . this cannot be the natural presumption, where it is not to be recollected from any particular provisions in the Constitution. . . . It is far more rational to suppose that the courts were designed to be an intermediate body between the people and the legislature, in order, among other things, to keep the latter within the limits assigned to their authority.

The Federalist No. 78, supra note 56, at 467 (A. Hamilton). The First Congress had evidently contemplated that even state courts might hold federal statutes invalid: section 25 of the Judiciary Act gave the Supreme Court jurisdiction to review state court judgments "where is drawn in question the validity of a treaty or statute of . . . the United States, and the decision is against their validity." Judiciary Act of 1789, ch. 20, § 25, 1 Stat. 73, 85 (current version at 28 U.S.C. § 1257 (1976)). But see A. BICKaL, supra note 69, at 13 ("one may as easily conclude that the Supreme Court was meant only to enforce against state courts a rule that duly enacted federal statutes are constitutional by virtue of their due enactment"); 2 W. CrosskeY, supra note 55, at 1029-33. See also 3 A. BEveridge, supra note 11, at 75, 116, 119 (observing that all of Marshall's arguments had been rehearsed in the congressional debate over the repeal of the Judiciary Act). See 11 Annals op Cong. 23$186,362-63,475-78,510-986,1203-35$ (1801).

${ }^{71}$ See infra notes 215-21, 264-68, 321-23, and accompanying text (discussing Hodgson v. Bowerbank, Cohens v. Virginia, and Osborn v. Bank of the United States); Trustees of 
Marshall began his discussion of judicial review by making the reader want to find that the Court could strike down unconstitutional statutes. The reason for adopting a written constitution was to limit legislative power; ${ }^{72}$ to require judges to enforce unconstitutional laws would give Congress "a practical and real omnipotence, with the same breath which professes to restrict their powers within narrow limits."73 This rhetoric, borrowed from The Federalist without attribution, ${ }^{74}$ was masterful. Surely the Framers were reasonable people, and surely they could not have meant to appoint the fox as guardian of the henhouse. ${ }^{78}$

It is noteworthy that the foregoing argument was derived from the nature of written constitutions in general, not from any particular provision of the Constitution Marshall was construing. ${ }^{76}$ The same was true of his equally pivotal contention that judicial review

Dartmouth College v. Woodward, 17 U.S. (4 Wheat.) 518 (1819). The Convention debates were not available to Marshall, but The Federalist had been cited as early as 1798 . See Currie, supra note 1 , at 830,867 . See also 3 A. Beveridge, supra note 11, at 119 (noting that Marshall had read The Federalist and adding that "no case ever was decided in which a judge needed so much the support of judicial precedents" as in Marbury).

725 U.S. (1 Cranch) at 176.

7s Id. at 178.

74 See The Fedrralist No. 78, supra note 56, at 466 (A. Hamilton):

By a limited constitution, I understand one which contains certain specified exceptions to the Legislative authority; such, for instance, as that it shall pass no bills of attainder, no ex post facto laws, and the like. Limitations of this kind can be preserved in practice no other way than through the medium of the courts of justice; whose duty it must be to declare all acts contrary to the manifest tenor of the Constitution void.

7s Compare Marshall's own argument elsewhere in Marbury that for every right there is a remedy, 5 U.S. (1 Cranch) at 163, and the argument of Justice Wilson in Chisholm v. Georgia, 2 U.S. (2 Dall.) 419, 465 (1793) (separate opinion), that the contract clause implied that states could be sued to enforce their obligations: "What good purpose could this constitutional provision secure, if a state might pass a law, impairing the obligation of contracts; and be amenable, for such a violation of right, to no controlling judiciary power?" For a further example of Marshall's strategy of beginning by demonstrating the horrible consequences of not reaching his conclusion, see infra notes 262-64 and accompanying text (discussing Cohens $v$. Virginia).

7o Indeed, Marshall overstated his case badly by asserting that judicial review was "essentially attached to a written constitution." 5 U.S. (1 Cranch) at 177. Not only is it possible to conceive of a written constitution that limits legislative power while precluding judicial review, but European experience has given us concrete examples. For example, Fresch Const. tit. 3, ch. 5, art. 3 (1789, repealed 1791), provided that "[t] fere in the exercise of legislative power, nor suspend the execution of laws." See C. Haings, The American Doctring or Judicial Supremacy 6-9 (1932) (citing, among others, the constitutions of France (1875), Belgium (1830), and Switzerland (1874)); J. TraYER, supra note 41, at 78 (Marshall "assumes as an essential feature of a written constitution what does not exist in any one of the written constitutions of Europe."); J. ThaYkR, LgGal Essays 2-3 (1908); Cappelletti \& Adams, Judicial Review of Legislation: European Antecedents and Adaptations, 79 HARv. L. REv. 1207, 1211-13 (1966). Hamilton's language of "presumption," see supra note 70 , would have been more appropriate. 
was inherent in the process of deciding cases, ${ }^{77}$ although the supremacy clause would have lent substantial support to his crucial description of the Constitution as "the fundamental and paramount law of the nation." "supreme Law of the Land,"79 that clause eliminated the possibility that the document should be regarded, as Chase had regarded Georgia's separation-of-powers provision, ${ }^{80}$ as merely precatory; ${ }^{81}$ and in declaring that state court judges were "bound thereby," it established that the Constitution was judicially enforceable. ${ }^{82}$

Like Chief Justice John Jay and Justice James Wilson in Chisholm, ${ }^{83}$ Marshall turned to the words of the Constitution only as an afterthought: the "peculiar expressions of the constitution of the United States furnish additional arguments" for judicial review. ${ }^{84}$ We might well have been tempted to begin with the constitutional language, as recent opinions have admonished with regard to statutes; 8 in so doing we might well have written a less powerful

${ }^{77}$ It is, emphatically, the province and duty of the judicial department, to say what the law is . . . . So, if a law be in opposition to the constitution; . . . the court must determine which of these conflicting rules governs the case . . . If then, . . . the constitution is superior to any ordinary act of the legislature, the constitution, and not such ordinary act, must govern the case to which they both apply.

5 U.S. (1 Cranch) at 177-78. Hamilton had said this too:

The interpretation of the laws is the proper and peculiar province of the courts. A Constitution is, in fact, and must be regarded by the Judges as a fundamental law .... If there should happen to be an irreconcilable variance between [it and a legislative act,] that which has the superior obligation and validity ought, of course, to be preferred: or in other words the Constitution ought to be preferred to the statute . . . . The Federalist No. 78, supra note 56, at 467 (A. Hamilton). Of course these arguments beg the question; it would be quite consistent with a judicial duty to declare the law to find that the law commits to Congress the decision whether it has acted within its powers. See A. Bicket, supra note 69, at 3; cf. G. GuNTHER, supra note 26, at 449. As Justice Gibson said in Eakin v. Raub, 12 Serg. \& Rawle 330,349 (Pa. 1825), "no one will pretend, that a judge would be justifiable in calling for the election returns, or scrutinizing the qualifications of those who composed the legislature," though legislative power is vested only in those qualified and elected.

28 5 U.S. (1 Cranch) at 177 ("Certainly, all those who have framed written constitutions contemplate them as forming the fundamental and paramount law of the nation ....").

79 U.S. Const. art. VI, para 2.

${ }^{80}$ Cooper v. Telfair, 4 U.S. (4 Dall.) 14, 18 (1800) (separate opinion) ("The general principles contained in the constitution are not to be regarded as rules to fetter and controul; but as matter merely declaratory and directory . . . ."). See Currie, supra note 1, at 880.

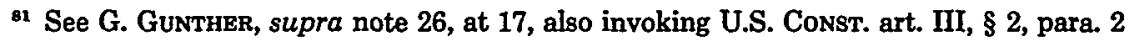
("Cases . . . arising under this Constitution").

32 It did not, of course, answer the critical question whether the judges were to accept Congress's interpretation of the Constitution rather than adopting their own.

ss See Currie, supra note 1, at 832-33.

* 5 U.S. (1 Cranch) at 178.

ss E.g., Watt v. Alaska, 451 U.S. 259, 265 (1981). 
opinion.

Marshall drew support from three specific constitutional provisions. The last he put forward with considerable hesitation: "It is ... not entirely unworthy of observation" that not all federal laws are declared supreme, "but those only which shall be made in pursuance of the constitution." 86 A law contravening the Constitution, he implied, had not been made "in Pursuance" of it. Yet the same clause also gives supremacy to "all Treaties made, or which shall be made, under the Authority of the United States."87 As the Court had held in Ware $v$. Hylton, ${ }^{88}$ this provision embraces treaties made both before and after adoption of the Constitution; the contrast strongly suggests that the reference to laws made in pursuance of "this Constitution" was meant to distinguish those made under the Articles of Confederation. ${ }^{80}$ Indeed, if this interpretation is correct, the supremacy clause furnishes a powerful argument against judicial review of Acts of Congress. Although the clause plainly gives the Constitution the right of way over competing state law, it appears to equate federal statutes with the Constitution by declaring them both "supreme law."

Marshall also invoked the provision of article VI that judges "shall be bound by Oath or Affirmation to support this Constitution":91 "How immoral to impose it on them, if they were to be used as the instruments, and the knowing instruments, for violating what they swear to support!'"92 The response of Pennsylvania's Justice Gibson seems conclusive: the oath "must be understood in

${ }^{86} 5$ U.S. (1 Cranch) at 180 (construing U.S. ConsT. art. VI, para. 2). Cf. St. G. Tucker, 1 Appendix to Blackstone's Commentaries 369-70, in 1 Blackstone's Commentaries: WITH Notes or Reperence to the Constitution and Laws of the Federal Government of the United States; AND of the Commonwealth of Virginia (St. G. Tucker ed. 1803) [hereinafter cited as Tucker's Appendix to Blackstone].

s7 U.S. CoNST. art. VI, para. 2.

ss 3 U.S. (3 Dall.) 199, 237 (1796) (separate opinion of Chase, J.). See Currie, supra note 1 , at 864 .

so See Reid v. Covert, 354 U.S. 1, 16-18 (1957) (opinion of Black, J., for four Justices) (repudiating Marshall's suggested interpretation of the "Pursuance" language in order to establish that treaties, as well as statutes, were subject to judicial review). See also $2 \mathrm{~W}$. CrosskeY, supra note 55, at 955-96. Others have suggested the "Pursuance" phrase might refer to statutes passed in conformity with the procedural requirements of the Constitution. E.g., Van Alstyne, supra note 49 , at 20.

* See 2 W. Crosskey, supra note 55, at 984-85. But see C. Black, The People and the Court 8 (1960) ("If the conflict between the Constitution and the other kind of law is resolved in favor of the latter, then the Constitution is relegated not to an equal but to an inferior position.").

"U.S. Const. art. VI, para. 3.

" 5 U.S. (1 Cranch) at 180. Cf. 1 'Tucker's Appendix to Blackstone, supra note 86, at 355. 
reference to supporting the constitution, only as far as that may be involved in his official duty; and consequently, if his official duty does not comprehend an inquiry into the authority of the legislature, neither does his oath."9s

The strongest textual argument in Marbury was based upon article III, which extends the judicial power to "Cases . . . arising under this Constitution." "Could it be the intention of those who gave this power, to say, that in using it, the constitution should not be looked into? That a case arising under the constitution should be decided, without examining the instrument under which it arises? This is too extravagant to be maintained." ${ }^{95}$ On its face, however, the arising-under clause appears to be merely a jurisdictional provision; it need not be taken to dictate when the Constitution must be given precedence over other laws. ${ }^{96}$ To that question the supremacy clause speaks directly, and that clause, as we have seen, seems to subordinate only state or executive action, not Acts of Congress, to the Constitution.

Thus we are left with no obvious peg on which to hang Marshall's conclusion. This is not to say he was wrong. The purpose of the supremacy clause seems to have been to declare the primacy of federal over state law; it need not be read to rebut the inference, based upon the Framers' statements and the presumption that they meant the limitations on Congress to be meaningful, that judicial review of federal statutes is implicit in the arising-under clause or in the limitations themselves. ${ }^{97}$ What is interesting is that Marshall chose to make the question appear much easier than it was.

There remains a crucial ambivalence in the Marbury opinion. Two disparate principles impelled Marshall to find judicial review in the Constitution: that it is an incidental byproduct of the task of deciding cases, and that it is the only means of enforcing constitutional limitations. Although these two arguments converged to

93 Eakin v. Raub, 12 Serg. \& Rawle 330, 353 ( $\mathrm{Pa}$. 1825) (emphasis in original). See also 2 W. Crosskey, supra note 55, at 983-84.

os U.S. Const. art. III, § 2, para. 1 .

${ }^{96} 5$ U.S. (1 Cranch) at 179.

os See A. Bicker, supra note 69, at 5-6.

97 Two basic counterarguments have been made to this part of Marshall's opinion: that it ignores the corresponding need for a check on the courts, A. BickEL, supra note 69, at 3-4, and that if the Framers had meant the courts to restrain Congress they would not have given the latter so much power to frustrate review by such devices as restricting the appellate jurisdiction, $2 \mathrm{~W}$. Crosskey, supra note 55, at 981-82. These two objections contradict each other; the net result seems to be that no branch of government is free from significant checks if there is judicial review. 
support the result in Marbury, they suggest divergent answers to a number of important related questions. If judicial review is merely incidental, the constitutional plan is not endangered if Congress withdraws the Court's appellate jurisdiction in constitutional cases, ${ }^{88}$ or if it packs the Court with additional Justices of its own persuasion, ${ }^{89}$ or if no one has standing to challenge a spending program. ${ }^{100}$ All of these possibilities, however, raise serious problems if judicial review is an essential part of our system of checks and balances.

In short, we find in Marbury a number of traits that were to characterize many later Marshall opinions: great rhetorical power, invocation of the constitutional text less as the basis of decision than as a peg on which to hang a result evidently reached on other grounds, a marked disdain for reliance on precedent, extensive borrowing of the ideas of others without attribution, an inclination to reach out for constitutional issues that did not have to be decided, a tendency to resolve difficult questions by aggressive assertion of one side of the case, and an absolute certainty in the correctness of his conclusions. We also see in Marbury the work of a masterful tactician, for Marshall managed to lay the basis for enormous judicial power in the future by sacrificing a trivial portion of the Court's jurisdiction in the immediate case. ${ }^{101}$

\section{B. Stuart v. Laird}

In 1801 the outgoing Federalist Congress finally abolished the arduous circuit-riding duties of Supreme Court Justices, establishing a new set of circuit courts manned by sixteen new Federalist judges. ${ }^{102}$ The next year the Republican Congress did away with the new courts and put the Justices back on circuit. ${ }^{103}$

st See, e.g., H.R. 867, 97th Cong., 1st Sess., 127 Conc. REc. H4116 (daily ed. Jan. 12, 1981) ("Notwithstanding the provisions of sections 1253, 1254, and 1257 of this chapter the Supreme Court shall not have jurisdiction to review, by appeal, writ of certiorari or otherwise, any case arising out of any State statute . . . relating to abortion.").

See S. 1392, 75th Cong., 1st Sess., 81 Cong. Rec. 5639, 6787-6814, 7375-81 (1937); S. REP. No. 711, 75th Cong., 1st Sess. (1937).

100 See Massachusetts v. Mellon, 262 U.S. 447 (1923). See also 1 C. WARREN, supra note 23 , at 222-24 (describing the Jeffersonians' rearrangement of judicial terms so that the Supreme Court could not meet for 14 months); id. at 269-315 (describing the impeachment of Justice Chase).

101 See R. McCloskey, The American Supreme Court $41-42$ (1960); Corwin, supra note 49 , at 543 .

${ }^{102}$ Act of Feb. 13, 1801, ch. 4, $\S 7,27,2$ Stat. 89, 90, 98 (repealed 1802). See G. HAsKINS \& H. JoHnson, supra note 24, at 107-35; 1 C. WARREN, supra note 23, at 185-89.

${ }^{\text {1os }}$ Act of Mar. 8, 1802, ch. 8, $\S \S 1,3,2$ Stat. 132, 132 (repealed 1911); Act of Apr. 29, 
Having obtained a judgment from one of the courts created by the 1801 Act, Laird sought to enforce it in the court to which jurisdiction had béen transferred by the 1802 Act. The defendant Stuart argued that this court had no jurisdiction because the statutes replacing the 1801 courts were unconstitutional. Chief Justice Marshall rejected Stuart's contentions at the circuit level and recused himself from reviewing his own decision. The Supreme Court affirmed in three brief paragraphs delivered by Justice Paterson, six days after Marbury.

The most fundamental objection to the 1802 Act was that, by abolishing the courts established in 1801, it had put out of their jobs sixteen judges who under article III were entitled to "hold their Offices during good Behaviour."104 In support of the Act, counsel invoked the reference in the same section to "such inferior Courts as the Congress may from time to time ordain and establish": 105 "The tenure of office . . . cannot take away altogether the right to alter and modify existing courts."108 Even Stuart's attorney, arguing against the statute, had to admit Congress could limit the jurisdiction of existing courts, ${ }^{107}$ and it is not easy to determine where the line should be drawn. Later Justices were to assume that article III judges could not be discharged by abolishing their courts, ${ }^{108}$ and Chase said so privately at the time, ${ }^{109}$ but the Court avoided the question in Stuart. Counsel had contended that the

1802 , ch. $31, \S 4,2$ Stat. 156, 157-58 (repealed 1911). For the political background of the repeal of the 1801 Act, see R. ElLIs, supra note 39, at 36-52.

${ }^{104}$ U.S. Const. art. III, § 1. See 5 U.S. (1 Cranch) at 303-04 (Mr. Lee).

105 U.S. ConsT. art. III, $\$ 1$.

106 U.S. (1 Cranch) at 307 (Mr. Gantt). Gantt might have added, as John Taylor of Caroline had argued, that the constitutional provisions (judges "shall hold their Offices," "during their continuance in Office") presupposed the continued existence of the office itself. See G. Haskins \& H. Johnson, supra note 24, at 153-54.

${ }^{107} 5$ U.S. (1 Cranch) at 304-05 (Mr. Lee).

${ }^{108}$ See Glidden v. Zdanok, 370 U.S. 530, 544-47 (1962) (opinion of Harlan, J.), and O'Donoghue v. United States, 289 U.S. 516, 535-38 (1933), both explaining Congress's power to vest judicial power in "legislative" courts in the territories on the ground that, if article III governed, the government would be, as stated in Glidden, "left . . . with a significant number of territorial judges on its hands and no place to put them" when a territory became a state. 370 U.S. at $545-46$.

${ }^{100}$ See Letter from Samuel Chase to John Marshall (Apr. 24, 1802), reprinted in G. HASKINS \& H. Johnson, supra note 24, at 172-77 n.182. Story was of the same opinion. See 3 J. Story, Commentaries on the Constitution of the United States 494-95 (Boston 1833) (arguing that the repeal "prostrates in the dust the independence of all inferior judges, ... and leaves the constitution a miserable and vain delusion"). St. George Tucker, whom Crosskey characterized as a "prominent Jeffersonian[]," 2 W. CrosskeY, supra note 55, at 764, was less direct but seemed to reach the same conclusion in 1803. 3 Tucker's Appendix to Blackstone, supra note 86 , at 25. 
various provisions of the statute were severable: it was admitted that Congress could transfer cases from one tribunal to another, and thus the tenure of the ousted judges "does not belong to this case." "110 The Court did not mention the circuit judges; it found no constitutional limit on the power "to transfer a cause from one... tribunal to another."111

The Court did, however, decide a second constitutional question: whether Supreme Court Justices could constitutionally sit on circuit. There were three arguments that they could not. First, a litigant in the Supreme Court had a right to have his case determined by six unbiased Justices. ${ }^{112}$ There were six Justices rather than four or five, however, only because Congress had said so. ${ }^{113}$ The suggestion of bias is reminiscent of later decisions under the due process clause, ${ }^{114}$ but those decisions reflect an interpretation that the Court would not embrace for many years, ${ }^{115}$ and it is not certain that they would govern today.

Second, it was argued that the statute assigning circuit duties to the Justices effectively appointed them as circuit judges, in contravention of article II's provision that appointments were to be made by the President with Senate consent. ${ }^{116}$ This contention was

2105 U.S. (1 Cranch) at 306-07 (Mr. Gantt).

111 Id. at 309. Chase did not note a dissent, though he had earlier written Marshall that any judge who held court under the new scheme "thereby, decides that the repealing was constitutional." G. HAskins \& H. JoHNSON, supra note 24 , at $172,175$.

Beveridge reported that the ousted judges did not, like Marbury, bring their own actions to recover their positions or their salaries: despite initial efforts, "their energies flagged, their hearts failed, and their only action was a futile and foolish protest to the very Congress that had wrested their judicial seats from under them." $3 \mathrm{~A}$. BeverIDGE, supra note 11, at 123. Chase wrote that the law gave the judges no remedy. Letter from Samuel Chase to John Marshall (Apr. 24, 1802), reprinted in G. Haskins \& H. JoHNSON, supra note 24, at 174-75. Warren stated that one of the judges did sue but said nothing of the outcome.

1 C. WARREN, supra note 23 , at 272 n.1.

1125 U.S. (1 Cranch) at 305-06 (Mr. Lee).

s1s See Chisholm v. Georgia, 2 U.S. (2 Dall.) 419, 432 (1793) (Iredell, J., dissenting).

114 U.S. Const. amend. V; id. amend. XIV, § 1. See Withrow v. Larkin, 421 U.S. 35,58 n.25 (1975) (dictum) (speaking in the context of state administrative proceedings: "[W]hen review of an initial decision is mandated, the decisionmaker must be other than the one who made the decision under review.") (citing Gagnon v. Scarpelli, 411 U.S. 778, 785-86 (1973), and Morrissey v. Brewer, 408 U.S. 471, 485-86 (1972)).

116 As late as 1856 the Court defined due process as conformity with "those settled usages and modes of proceeding existing in the common and statute law of England, before the emigration of our ancestors," Murray's Lessee v. Hoboken Land \& Improv. Co., 59 U.S. (18 How.) 272, 277 (1856); in England judges habitually sat in review of their own decisions. The Justices were soon to abandon their early practice of refusing to review their own decisions. See Shirras v. Caig, 11 U.S. (7 Cranch) 34, 42 n.(a) (1812), cited (with a minor inaccuracy) in T. Sergeant, Constitutional Law 102 (Philadelphia 1822).

1105 U.S. (1 Cranch) at 305 (Mr. Lee) (construing U.S. Const. art. II, § 2, para. 2). 
not at all frivolous. Although not every addition to a court's jurisdiction should be held to require a new appointment, some limit on congressional reassignment of the functions of incumbent officers seems implicit if the President's authority is not to be circumvented. ${ }^{117}$

The final argument drew strength from Marbury v. Madison: the Justices could not sit on circuit because the cases they would try there were outside the Supreme Court's original jurisdiction as defined by article III. ${ }^{118}$ The immediate response to this argument is that it is not the Supreme Court but one of its members who exercises original jurisdiction; by the time the Court decides the case, it has the benefit of a decision below and is spared the collective burden of conducting a trial. The difficulty is that this response, by separating the Justice from the Court, strengthens the alternative objection that circuit riding is a distinct office requiring an additional appointment. To reject both contentions one must draw a delicate distinction: the new duties are a part of the existing. office of Justice, but not a function of the Supreme Court as an institution.

The Court upheld the power of Congress to send the Justices out on circuit, but it did so without refuting any of the contrary arguments: "[P]ractice, and acquiescence under it, for a period of several years, commencing with the organization of the judicial system, affords an irresistible answer, and has indeed fixed the construction .... . Of course, the question is at rest, and ought not now to be disturbed."119

Deference to legislative interpretation of the Constitution had been suggested by Chase and other Justices some time before, in repeated statements that legislation was not to be set aside except in a "clear" case. ${ }^{120}$ Story was to make a particular point of the weight to be given the judgment of the First Congress, many of whose members had been at the Constitutional Convention, in Martin v. Hunter's Lessee. ${ }^{121}$ But neither Chase nor Story ever contended that the Court was bound by Congress's interpretation; to hold that it was would overrule Marbury $v$. Madison.

117 For example, if Congress were to assign all the duties of the Secretary of State to his Assistant Secretary, or to the Secretary of the Treasury.

${ }^{118} 5$ U.S. (1 Cranch) at 305 (Mr. Lee).

119 Id. at 309.

120 See Calder v. Bull, 3 U.S. (3 Dall.) 386, 395 (1798) (Chase, J.); id. at 399 (Iredell, J.); Hylton v. United States, 3 U.S. (3 Dall.) 171, 175 (1796) (Chase, J.).

122 See infra note 227 and accompanying text. See also McCulloch v. Maryland, 17 U.S. (4 Wheat.) 316, 400-01 (1819). 
The Stuart opinion did not rest upon the action of the First Congress alone; it invoked the Court's own "acquiescence" in circuit riding from 1789 until $1801 .^{122}$ Once again the contrast with Marbury is striking: counsel had there cited previous cases in which the Court had allegedly entertained original mandamus requests, and Marshall did not bother to respond. ${ }^{123}$ Two years later, in United States $v$. More, ${ }^{124}$ Marshall would expressly decline, as we would be likely to decline today, ${ }^{125}$ to treat as binding precedent a decision in which the issue had been neither litigated nor decided. ${ }^{126}$ Moreover, the Court's "acquiescence" had been less than absolute. The Justices had agitated repeatedly for relief from circuit duty ${ }^{127}$ and had protested to the President on constitutional grounds as early as $1790 .{ }^{128}$ Finally, neither legislative practice nor judicial acquiescence should have been decisive of whether a presidential appointment was required. The Act of 1802 was the first to impose circuit duties upon Justices previously appointed. ${ }^{129}$

1225 U.S. (1 Cranch) 309.

${ }^{123}$ See supra note 58.

1247 U.S. (3 Cranch) 159 (1805).

${ }^{128}$ See, e.g., Stone v. Powell, 428 U.S. 465, 481 n.15 (1976), and the contrary view expressed with respect to jurisdictional questions in the dissent, id. at 518-19 (Brennan, J., dissenting).

${ }^{226} 7$ U.S. (3 Cranch) at 172; see infra notes 130-44 and accompanying text. But see The Betsey \& Charlotte, 8 U.S. (4 Cranch) 443, 452 (1808) (Marshall, C.J.), discussed in Currie, supra note 1 , at $843-44$.

127 See 1 C. WARREN, supra note 23, at 31-90.

${ }^{128}$ This letter from the Justices to George Washington (1790), with Washington's request for the Justices' remarks (Apr. 3, 1790), is reprinted in 3 J. STORY, supra note 109, at 438-41. The Justices made both of the principal arguments later advanced in Stuart. Contrast the well-known Correspondence of the Justices, supra note 41 , three years after this letter, refusing to answer a similar request for advice respecting our neutrality in the war between England and France.

120 The Justices had debated among themselves, in a series of letters, whether or not they should refuse on constitutional grounds to sit on circuit. Marshall, who had expressed "strong constitutional scruples," Letter from John Marshall to William Paterson (Apr. 6, 1802), quoted in G. Haskins \& H. Johnson, supra note 24, at 168, suggested the possibility of distinguishing between "the original case of being appointed to duties marked out before their appointments, and of having the duties of administering justice in new Courts imposed after their appointments," but he thought it unconvincing and added that "[t]he law having been once executed will detract very much, in the public estimation, from the merit or opinion of the sincerity of a determination not now to act under it." Letters from John Marshall to William Paterson (Apr. 6 \& 24, 1802), quoted in 1 C. WARREN, supra note 23, at 269-71. Warren praised Stuart as a "striking example of the non-partisanship of the American Judiciary." 1 C. WARREN, supra note 23, at 272. Given the Court's precarious position under the Jeffersonian siege, see G. Haskins \& H. JoHsson, supra note 24, at 136-181; 1 C. WARRBN, supra note 23 , at $169-315$, it may be more accurate to describe the decision as an exercise in self-preservation. 


\section{United States v. More}

More, like Marbury, had been appointed to a five-year term as justice of the peace in the District of Columbia. At the time of his appointment the statute authorized him to collect fees for his services. The new Republican Congress repealed the fee provision in 1802 , and More was prosecuted for taking a subsequent fee. $\mathrm{He}$ demurred on the ground that the statute abolishing his fees offended article III's guarantee that federal judges should receive "Compensation, which shall not be diminished during their Continuance in Office." 130 The trial court sustained the demurrer by a divided vote, and the government went to the Supreme Court. ${ }^{131}$

The dissenting judge below had argued that More had been appointed not under article III but under Congress's article I power of "exclusive Legislation" over the District of Columbia ${ }^{132}$ and thus that he was not protected by the limitations of article III. ${ }^{133}$ The difficulty was not with the premise of this argument but with its conclusion: why was not Congress's power to create District of Columbia courts, like its power to regulate commerce, subject to the explicit limits found elsewhere in the Constitution? ${ }^{134}$ This was not the first case to present the difficult problem of fitting the District of Columbia and the territories into a constitutional scheme drafted essentially without thinking about them, and it was certainly not to be the last. ${ }^{135}$

In More, however, the Supreme Court managed to avoid deciding this question. For More's was a criminal case, and the Judiciary Act did not provide for Supreme Court review of criminal

1so U.S. Const. art. III, $\$ 1$.

1317 U.S. (3 Cranch) 159 (1805).

132 U.S. ConST. art. I, § 8, cl. 17 .

$1 s 37$ U.S. (3 Cranch) at 164-65 (footnote) (Kilty, J., dissenting).

1s4 As Judge Cranch had written below: "The true construction is, that Congress may legislate for us [in the District], in all cases where they are not prohibited by other parts of the constitution." Id. at 160. Judge Kilty did acknowledge in dissent that other constitutional limitations, such as the habeas corpus and ex post facto clauses and the first amendment, applied to the District; but article III's tenure provision, he concluded, was "evidently applicable [only] to the judicial power of the whole United States," and "not to a particular territory." Id. at 164-65. In the Supreme Court, counsel went further: "When legislating over the district of Columbia, congress are bound by no constitution." Id. at 171 (Mr. Mason). Cf. infra notes 415-35 and accompanying text (discussing American Insurance Co. $v$. Canter).

1ss See, e.g., Loughborough v. Blake, 18 U.S. (5 Wheat.) 317 (1820); infra notes 164-78, 260-98, 415-35, and accompanying text (discussing Hepburn v. Ellzey, Cohens v. Virginia, and American Insurance Co. v. Canter). In Palmore v. United States, 411 U.S. 389 (1973), the Court, after contrary suggestions in intervening opinions, adopted Judge Kilty's position that local judges in the District of Columbia need not be given article III tenure. 
cases. ${ }^{138}$ More itself was governed by a separate statute authorizing review of "final judgment[s]" of the District of Columbia court, but Marshall for the Court read the further provision for a minimum jurisdictional amount as indicating that only civil cases were included..$^{138} \mathrm{He}$ repeated, without citation, Justice Wilson's earlier conclusion $^{139}$ that the Supreme Court's constitutional appellate jurisdiction would have been self-executing in the absence of congressional action. ${ }^{140} \mathrm{He}$ added, however, that by enacting statutes listing cases the Court could hear, Congress had implicitly exercised its article III authority to make "Exceptions" to the appellate jurisdiction: "[A]n affirmative description of [the Court's] powers must be understood as a regulation, under the constitution, prohibiting the exercise of other powers than those described."141

No one suggested in More that there might be any doubt of Congress's power to except criminal cases from the appellate jurisdiction. The words of article III are unqualified, but after Marbury it was not obvious that the power to make exceptions was absolute. Marbury had suggested that judicial review was implicit in constitutional provisions restricting congressional power; ${ }^{142}$ arguably even the exceptions authority could not be used to deny a forum for the claim that Congress had offended the compensation clause of article III. ${ }^{143}$ More himself had had his day in the court below, and he had won; the decision cannot be taken to mean there are no limits to Congress's power to curtail the appellate jurisdiction. Yet it is of some importance that no one seems to have doubted that Congress could close the Supreme Court itself to an important constitutional claim. ${ }^{144}$

1se See Judiciary Act of 1789 , ch. 20,1 Stat. 73 (current version in scattered sections of 28 U.S.C. (1976 and Supp. IV 1980)).

137 Act of Feb. 27, 1801, ch. 15, § 8, 2 Stat. 103, 106 (current version at 28 U.S.C. $\$ 1257$ (1976)).

1887 U.S. (3 Cranch) at 173-74.

130 Wiscart v. D'Auchy, 3 U.S. (3 Dall.) 321, 325 (1796), discussed in Currie, supra note 1 , at $845-49$.

140 7 U.S. (3 Cranch) at 176. When Marshall reaffirmed this point and the one next discussed in Durousseau v. United States, 10 U.S. (6 Cranch) 307, 313-14 (1810), he cited neither Wiscart nor More.

141 U.S. (3 Cranch) at 173. See also id. at 170-71. To the argument that the Court had exercised appellate jurisdiction in an earlier criminal case, Marshall responded that the question of jurisdiction had not there been raised: "It passed sub silentio, and the court does not consider itself as bound by that case." Id. at 172.

${ }_{142}$ See supra notes 72-73 and accompanying text.

112 For additional considerations relevant to this point, see Currie, supra note 1, at 84749.

144 In Durousseau v. United States, 10 U.S. (6 Cranch) 307 (1810), the Court similarly 


\section{Ex parte Bollman}

Bollman and Swartwout, implicated in Aaron Burr's mysterious western adventures, ${ }^{145}$ had been jailed by a District of Columbia court to await trial on charges of treason. They filed a petition for habeas corpus in the Supreme Court, which in 1807 ordered them discharged. ${ }^{148}$

The Court's jurisdiction to entertain the petition was challenged on both statutory and constitutional grounds. Section 14 of the Judiciary Act purported to give all federal courts "power to issue writs of scire facias, habeas corpus, and all other writs not specially provided for by statute, which may be necessary for the exercise of their respective jurisdictions."147 Over Justice Johnson's dissent, the Court construed the clause limiting it to writs in aid of jurisdiction as applying only to "other writs" and not to habeas corpus; ${ }^{148}$ it did not suggest that the statute should be read nar-

did not decide what limits there might be to Congress's power to make exceptions, and no argument to that effect is reported. After repeating the points made in More, the Court in Durousseau held that Congress had not implicitly forbidden review of decisions by the District Court for the Territory of New Orleans. Constitutional scruples may, however, have underlain Marshall's expressed reluctance in Durousseau to find that Congress had intended the District Court of New Orleans to be, "in fact, . . . a Supreme Court." 10 U.S. (6 Cranch) at 318. Compare U.S. CoNsT. art. III, \& 1, which speaks of "one Supreme Court." Yet he had earlier referred to the Court's acceptance of a minimum-amount requirement for the exercise of its appellate jurisdiction, without suggesting it raised any constitutional problem. Id. at 314.

${ }^{145}$ For the historical setting of this case, see 3 A. BeVERIDGe, supra note 11, at 274-397; G. HaSkins \& H. JoHNSON, supra note 24, at 248-62; 1 C. WARREN, supra note 23, at 301-08. For the later adventures of the intrepid Sam Swartwout, see Murray's Lessee v. Hoboken Land Improvement Co., 57 U.S. (18 How.) 272 (1856); G. VIDAL, BurR 270-72, 363-69, 425 (1973).

1468 U.S. (4 Cranch) 75 (1807).

147 Judiciary Act of 1789 , ch. $20, \S 14,1$ Stat. $73,81-82$ (current version at 28 U.S.C. $\S 1651$ (1976)).

1488 U.S. (4 Cranch) at 95-100, 105. For discussion of the complicated statutory issues, see Oaks, The "Original" Writ of Habeas Corpus, 1962 Sup. Cr. Rev. 153, 173-76; Paschal, The Constitution and Habeas Corpus, 1970 Duks L.J. 605, 623-25. Professor Paschal argues that Marshall made an error of constitutional proportion in concluding, 8 U.S. (4 Cranch) at 93-94, that statutory authority was necessary to enable the Court to issue the writ. Paschal contends that article I's provision that "[t]he Privilege of the Writ of Habeas Corpus shall not be suspended, unless when in Cases of Rebellion or Invasion the public Safety may require it," U.S. CoNsT. art. I, \& 9, para. 2, "is a direction to all superior courts of record, state as well as federal, to make the habeas privilege routinely available"; the statement in Bollman means "that Congress can suspend the privilege in the federal courts at its pleasure, whether or not the public safety requires it," by withholding jurisdiction to grant the writ. Paschal, supra, at 605,607 . The thesis that article $I$ requires that some court have habeas jurisdiction was accepted in Eisentrager v. Forrestal, 174 F.2d 961, 966-67 (D.C. Cir. 1949) (alternative holding), but because, so far as the report reveals, Paschal's argument was not squarely made in Bollman, the precedential value of Marshall's statement is less than 
rowly to avoid facing the constitutional question.

The constitutional question was that posed by Marbury: ${ }^{149}$ if to issue the writ would be to exercise original jurisdiction, the $\mathrm{Su}$ preme Court could not do it, because neither a state nor a foreign diplomat was a party. Marshall's response was brief, invoking Marbury's definition of the appellate power: the jurisdiction in Bollman was appellate because it involved "the revision of a decision of an inferior court, by which a citizen has been committed to gaol."1so

Marshall made his task in Bollman much easier by not quoting the actual language of the decision on which he relied. In Marbury he had said that "the essential criterion of appellate jurisdiction" was "that it revises and corrects the proceedings in a cause already instituted and does not create that cause."1s1 As applied to Bollman, this passage contains a crucial ambiguity. For though, as Marshall stressed, Bollman was an effort to "revise and correct" the decision of another judge, ${ }^{152}$ it was not so clear that it was a part of the "cause already instituted." In later refusing to take jurisdiction of a habeas proceeding under a statute limited to criminal cases, for example, the Court would say that the writ was "not a proceeding in the [criminal] prosecution" but "a new suit brought . . . to enforce a civil right."16s Yet it would be a mistake to attribute to the Framers any purpose that would render the dis-

\footnotetext{
complete.

149 See supra notes 51-53 and accompanying text.

1308 U.S. (4 Cranch) at 101.

1815 U.S. (1 Cranch) at 175.

18s 8 U.S. (4 Cranch) at 101.
}

${ }^{133}$ Ex parte Tong, 108 U.S. 556, 559-60 (1883). Cf. Fay v. Noia, 372 U.S. 391, 428, 430 (1963) (describing the present statutes providing for district court habeas as furnishing "an independent, collateral remedy" and holding inapplicable to habeas proceedings the adequate state ground limitation applicable to direct Supreme Court review of state court judgments because, inter alia, the language of the habeas statute was "hardly characteristic of an appellate jurisdiction"). Compare also Paschal, supra note 148, at 626 , discussing counsel's argument in Ex parte Burford, 7 U.S. (3 Cranch) 448, 449 (1806), that a case involving habeas corpus could be distinguished from Marbury because mandamus is a prerogative writ while the Constitution makes habeas a "writ of right," and therefore not subject to the restriction on the Supreme Court's original jurisdiction (Burford did not address this argument). Compare also In re Metzger, 46 U.S. (5 How.) 176, 191 (1847), holding that habeas review of a commitment made by a district judge in chambers was not appellate and casting aspersions on Bollman while distinguishing it:

[T] here is some refinement in denominating that an appellate power which is exercised through the instrumentality of a writ of habeas corpus. In this form nothing more can be examined into than the legality of the commitment. However erroneous the judgment of the court may be, . . . if it had jurisdiction, and the defendant has been duly committed, under an execution or sentence, he cannot be discharged by this writ. 
tinction between original and appellate power one of form rather than substance; the underlying policies of sparing the Supreme Court trial burdens and of affording it the benefit of lower court views were satisfied in Bollman.1st

Marshall also invoked more specific precedents: in two earlier cases the Court had issued the writ under similar circumstances. ${ }^{155}$ In the first, so far as the report reveals, the constitutional issue had not been raised; by the standard announced by Marshall two years earlier in More, ${ }^{156}$ it was entitled to no precedential weight. Marshall had decided the second case in 1806 on the basis of the first-in disregard of his own statement in More. Johnson, naturally, invoked More. ${ }^{187} \mathrm{He}$ added, more generally, that the salutary doctrine of stare decisis was not an absolute command:

I deny, that a court is precluded from the right, or exempted from the necessity, of examining into the correctness or consistency of its own decisions.... . Strange indeed would be the doctrine, that an inadvertency once committed by a court shall ever after impose on it the necessity of persisting in its error. ${ }^{158}$

The Court would have ample opportunities later on to agree with him. ${ }^{180}$

186 Johnson dissented on the constitutional ground as well, arguing rather obscurely that any habeas jurisdiction conferred by section 14 was original because the Court's statutory power was identical to that of a district court. 8 U.S. (4 Cranch) at 106.

${ }_{16 s}$ Id. at 101 (citing United States v. Hamilton, 3 U.S. (3 Dall.) 17 (1795), and Ex parte Burford, 7 U.S. (3 Cranch) 448 (1806)).

1so See supra note 141.

1578 U.S. (4 Cranch) at 104.

158 Id. at 103-04. Johnson noted that he was "much relieved from the painful necessity of dissenting . . . , in being supported by the opinion of one of my brethren, who is prevented by indisposition from attending." Id. at 107. The reporter tells us, $i d$. at 93 n.(a), that both Cushing and Chase were absent, and, $i d$. at iii, that Cushing was absent for the entire Term. 3 A. Beveridge, supra note 11, at 349 \& n.4, citing correspondence, said it was Chase who joined the dissent; T. SERgeant, supra note 115, at 66 , said flatly that it was Cushing.

Johnson added that he had objected to the issuance of the writ in Ex parte Burford, 7 U.S. (3 Cranch) 448 (1806), but had "submitted in silent deference to the decision of my brethren," 8 U.S. (4 Cranch) at 107. Later Justices seem to have felt a greater necessity to air publicly any disagreement with a majority opinion. Johnson's statement, taken with other evidence reported by Professor Morgan, supra note 13, at 168-69, leads one to wonder how many other cases there were in which the Marshall Court was less unanimous than the report reveals.

15s On the merits, and without recorded dissent, the Court proceeded in a second Marshall opinion to order the petitioners discharged for want of allegations sufficient to satisfy the constitutional definition of treason. Ex parte Bollman, 8 U.S. (4 Cranch) 126 (1807). Article III's provision that "Treason against the United States, shall consist only in levying 


\section{Diversity JuRISDiction}

Apart from the cases already considered, the Court's principal activity with constitutional overtones between 1801 and 1810 concerned the definition of federal jurisdiction in cases involving aliens or citizens of different states. Four decisions during this period dealt with this subject: Hepburn v. Ellzey, ${ }^{160}$ Strawbridge $v$. Curtiss, ${ }^{161}$ Bank of the United States v. Deveaux, ${ }^{182}$ and Hodgson v. Bowerbank. ${ }^{1 \mathrm{~s}}$

\section{A. Hepburn v. Ellzey}

The defendant was a citizen of Virginia, the plaintiff of the District of Columbia. The Judiciary Act provided jurisdiction over suits "between a citizen of the State where the suit is brought [here Virginia], and a citizen of another State."164 The circuit court certified the question of jurisdiction to the Supreme Court, ${ }^{185}$ which in two pages by Marshall held in 1805 that there was no jurisdiction. ${ }^{108}$

Marbury v. Madison suggested a threshold problem ${ }^{16 z}$ that apparently passed unobserved. The circuit court was sitting as a court of first instance, and it had not decided the certified question. Why wasn't the Supreme Court thus exercising a forbidden original jurisdiction? In 1838 the Court acknowledged that to de-

War against them, or in adhering to their Enemies, giving them Aid and Comfort," U.S. CoNST. art. III, $\S 3$, para. 1, was said to require not a mere conspiracy but "an actual assembling of men ... for the purpose of effecting by force a treasonable purpose," 8 U.S. (4 Cranch) at 126. The Justices divided as to whether evidence before the Court established that the expedition had been aimed at the United States, and all agreed there was no showing that an armed group had actually been assembled. Id. at 133, 135. For his interpretation of article III, Marshall relied not only on the constitutional text but on opinions of his brethren expressed on circuit. Id. at 127-28.

The treason decision in Bollman was an important precedent when Marshall on circuit presided over the trial of Burr himself, who was acquitted on the basis of Marshall's charge to the jury. United States v. Burr, 25 F. Cas. 55 (No. 14,693) (C.C.D. Va. 1807). For discussion of Burr, see, e.g., 3 A. BEvERIDGE, supra note 11, at 274-545; G. Haskins \& H. Johnson, supra note 24 , at $612-46$; 1 C. WARREN, supra note 23 , at 301-15.

${ }_{100} 6$ U.S. (2 Cranch) 445 (1805).

1617 U.S. (3 Cranch) 267 (1806).

1629 U.S. (5 Cranch) 61 (1809).

1ts 9 U.S. (5 Cranch) 303 (1809).

1et Judiciary Act of 1789 , ch. $20, \S 11,1$ Stat. 73,78 (current version at 28 U.S.C. $\S 1332$ (1976)).

${ }_{185}$ As authorized by Act of April 29, 1802, ch. 31, $\$ 2,2$ Stat. 156, 159 ("whenever any question shall occur before a circuit court, upon which the opinions of the judges shall be opposed") (current version at 28 U.S.C. $\$ \$ 1254,1255$ (1976)).

${ }^{16} 6$ U.S. (2 Cranch) $445,452-53$ (1805).

${ }^{167}$ See supra notes $51-53$ and accompanying text. 
cide the whole case on certified questions without a decision below would infringe the Marbury principle; ${ }^{108}$ the objection seems equally valid when the Court decides a single issue. ${ }^{169}$

Marshall's disposition of the diversity question was brief and straightforward. The jurisdictional statute "obviously uses the word 'state' in reference to that term as used in the constitution," and the provisions of articles I and II respecting congressional and presidential elections demonstrated that "the members of the American confederacy only are the states contemplated in the constitution."170

This is vintage Marshall. It may well have been fair to presume that the statute used the term in the constitutional sense and that constitutional usage was consistent throughout. Marshall's dogmatic declarations, however, suggest no possibility that context or consequences might show the contrary. Later cases have generally construed statutes conferring jurisdiction of cases "arising under" federal law to be less comprehensive than the identically worded constitutional provision, ${ }^{171}$ and corporations have come to be treated effectively as "citizens" under article III but not under article IV.172 Moreover, powerful reasons had been urged in Hepburn for holding the District a "state" for diversity purposes. District citizens, it had persuasively been argued, were as much in

168 White v. Turk, 37 U.S. (12 Pet.) 238, 239 (1838). See R. Stern \& E. Gressman, Supreme Court Practice 597-98 (5th ed. 1978).

188 See Wheeler Lumber Co. v. United States, 281 U.S. 572, 576 (1930) (reaffirming the holding of White $v$. Turk and adding that the power to decide single questions before decision below, while "rather exceptional in the appellate field," was "settled" by "[e]arly and long continued usage amounting to a practical construction of the constitutional provision"). ${ }^{170} 6$ U.S. (2 Cranch) at 452. Marshall extended this reasoning to a citizen of a territory in New Orleans v. Winter, 14 U.S. (1 Wheat.) 91, 94 (1816):

It has been attempted to distinguish a Territory from the District of Columbia; . . . but neither of them is a state, in the sense in which that term is used in the constitution. Every reason assigned for the opinion of the court, that a citizen of Columbia was not capable of suing in the courts of the United States, under the Judiciary Act, is equally applicable to a citizen of a territory.

171 Compare, e.g., Cohens v. Virginia, 19 U.S. (6 Wheat.) 264, 379 (1821) ("A case . . . consists of the right of the one party, as well as of the other, and may truly be said to arise under the constitution or a law of the United States [for purposes of article III], whenever its correct decision depends on the construction of either.") with Gold-Washing \& Water Co. v. Keyes, 96 U.S. 199 (1877) (disallowing removal based on a federal defense under the statutory provision for removal of cases "arising under the Constitution or laws of the United States").

172 Compare Marshall v. Baltimore \& O.R.R., 57 U.S. (18 How.) 314 (1854) (deeming members of corporation citizens of the state of incorporation for purposes of diversity jurisdiction) with Paul v. Virginia, 75 U.S. (8 Wall.) 168 (1869) (corporation not protected by the privileges and immunities clause). 
need of an impartial forum as were citizens of Maryland; ${ }^{173}$ Marshall acknowledged the term "state" was sometimes used to refer to any "distinct political society."174 In addition, if the Court was right that "state" had a single meaning throughout the Constitution, Congress would be free after Hepburn to tax exports from the District or to channel all foreign commerce there, despite article I's provisions forbidding Congress to tax articles "exported from any State"175 or to give preferences "to the Ports of one State over those of another."178 Marshall conceded it was "extraordinary" that federal courts should be closed to District citizens, "[b]ut this is a subject for legislative, not for judicial consideration."177 The "other passages" cited to show that "state" was "sometimes used in its more enlarged sense," he added without explanation, "do not prove what was to be shown by them."178

1736 U.S. (2 Cranch) at $448-49$ (E.J. Lee).

174 Id. at 452. Cf. infra notes $436-52$ and accompanying text (discussing Cherokee $\mathrm{Na}$ tion v. Georgia).

${ }^{276}$ U.S. ConsT. art. I, \& 9, cl. 5.

176 Id. cl. 6. This provision was invoked by E.J. Lee in his argument for the Distrivt. 6 U.S. (2 Cranch) at 451.

${ }_{172} 6$ U.S. (2 Cranch) at 453. Only a few days before, Marshall had written that "the legislative intention must be expressed with irresistible clearness" to persuade a court that the drafters of a statute meant to reach "mischie[vous]" results "[w]here rights are infringed, where fundamental principles are overthrown, where the general system of the laws is departed from"; but otherwise "it would be going a great way, to say that a constrained interpretation must be put upon [the words], to avoid an inconvenience which ought to have been contemplated." United States v. Fisher, 6 U.S. (2 Cranch) 358, 389-90 (1805). Compare Marshall's argument from "mischie[vous] results" in Marbury, supra notes 72-75 and accompanying text.

The reference to "legislative" consideration suggests Marshall was inviting Congress to extend jurisdiction to cases involving District citizens, see T. SRRGRant, supra note 115, at $110 \mathrm{n} .(\mathrm{x})$; C. Wrigrr, supra note 46, at 94 ; his equation of the statutory and constitutional language, however, suggests he would have thought any such statute unconstitutional. He seems rather to have been referring to the "legislative" process of constitutional amendment. A century and a half later, after Congress had taken up Marshall's suggestion, see 28 U.S.C. $\S 1332$ (d) (1976) ("The word 'States,' as used in this Section, includes the Territories, the District of Columbia, and the Commonwealth of Puerto Rico."), only two Justices would decline to follow Hepburn as an interpretation of the Constitution. National Mut. Ins. Co. v. Tidewater Transfer Co., 337 U.S. 582, 604, 617-26 (1949) (Rutledge \& Murphy, JJ., concurring). Three others concluded, however, that Congress could confer jurisdiction on the basis of its article I power to legislate for the District of Columbia, $i d$. at 588-604 (Jackson, Black \& Burton, JJ.), despite precedents treating article III as a limitation on the powrers Congress could give a federal court, see, e.g., Mossman v. Higginson, 4 U.S. (4 Dall.) 12 (1800) (alien a party); Hayburn's Case, 2 U.S. (2 Dall.) 409, 410-14 n.(a) (C.C.D.N.Y., C.C.D. Pa. 1792) (nonjudicial authority); see also Currie, supra note 1, at 852. Because Marshall found Congress had not attempted to extend jurisdiction to District citizens, he had no need in Hepburn to face this constitutional argument.

178 6 U.S. (2 Cranch) at 453. As to certain of the provisions that had been invoked, Marshall had a point. Counsel had argued that statutes extending full faith and credit and 


\section{B. Strawbridge v. Curtiss}

The plaintiffs and several defendants were citizens of Massachusetts; one defendant was a citizen of Vermont. The year after Hepburn, in three brief Marshall paragraphs, the Court affirmed a dismissal for want of jurisdiction. ${ }^{178}$

The statute, as noted above, gave jurisdiction of suits "between a citizen of the State where the suit is brought, and a citizen of another State."180 Marshall's reasoning consisted of a bald conclusion: "The court understands these expressions to mean, that each distinct interest should be represented by persons, all of whom are entitled to sue, or may be sued, in the federal courts." 182 That is, all plaintiffs must be diverse from all defendants.

This interpretation was certainly not compelled by the statutory language, and the purpose of the clause might be thought to require a federal forum whenever an out-of-stater was a party. Marshall could have helped his case by invoking the latter-day explanation that the presence of a local codefendant insulates the outsider from prejudice, ${ }^{182}$ perhaps it was some such consideration, rather than a simple disinclination to comment on a case not before the Court, that led him to reserve the question whether complete diversity was also required where the interests were not

extradition duties to the District and to the territories could be sustained only by giving a broad interpretation to the term "State" in article VI, while an oblique reference to "privileges and immunities" suggested that otherwise the states could treat the District citizen as an outcast. Id. at 450-52. All of these problems, however, Congress could deal with without stretching the word "state," under its power to exercise "exclusive Legislation". for the District of Columbia. U.S. CoNsT. art. I, \& 8, cl. 17. Marshall might have done better to explain all this, and none of it seems to answer the arguments respecting port preferences and export taxes, which are phrased in terms of "State[s]." Id. art. I, § 9, cls. 5 \& 6.

1797 U.S. (3 Cranch) 267 (1806).

${ }^{100}$ Judiciary Act of 1789 , ch. $20, \S 11,1$ Stat. 73, 78 (current version at 28 U.S.C. $\$ 1332$ (1976)).

181 7 U.S. (3 Cranch) at 267.

182 See the argument of counsel in Case of the Sewing Mach. Cos., 85 U.S. (18 Wall.) 553,572 (1874) ("When citizens of the State where the suit is, are on both sides in the suit, the local prejudice or influence is destroyed, or balanced. It favors one side as much as the other."). For the opposing view, see the concurring opinion of Justice Bradley in Removal Cases (Meyer v. Construction Co.), 100 U.S. 457, $479-80$ (1879), arguing that Strawbridge should not be followed in construing a similarly worded removal provision:

[T] hose terms include as well the case when only a part of the contestants opposed to each other are citizens of different States . . . . [The purpose] to establish a common and impartial tribunal . . . would be defeated in many cases if the fact that a single one of many contestants on one side of a controversy being a citizen of the same State with one or more of the contestants on the other side, should have the effect of depriving the federal courts of jurisdiction. 
"joint" but "distinct."18s

As in Hepburn, Marshall in Strawbridge purported only to construe the statute, but to judge by his Hepburn opinion equating statute and Constitution, he would have given the same construction to the Constitution. Later cases, however, have both extended the statutory Strawbridge rule to situations in which the interests are not joint ${ }^{184}$ and held that Congress may abolish it, at least in certain cases. ${ }^{185}$ If complete diversity was ever a constitutional requirement, ${ }^{186}$ it seems not to be any more.

\section{Bank of the United States $v$. Deveaux}

The "President, Directors and Company" of the First National Bank, alleging themselves to be citizens of Pennsylvania, filed a federal trespass action against Georgia citizens for carting silver away from the Bank's Savannah branch to satisfy an unpaid state tax. ${ }^{187}$ The circuit court dismissed for want of jurisdiction; the Supreme Court reversed in an 1809 Marshall opinion. ${ }^{188}$

This case was an early preview of the great controversies over state taxation of the Second National Bank that the Court was to resolve ten and fifteen years later in McCulloch $v$. Maryland ${ }^{189}$ and Osborn v. Bank of the United States. ${ }^{190}$ In Deveaux, however, the Court found it unnecessary to determine the constitutional scope of federal question jurisdiction or to pass upon the merits; it remanded for further proceedings on finding the suit was one between citizens of different states. ${ }^{191}$

Deveaux is commonly viewed today as having severely limited diversity jurisdiction, for Marshall expressly stated that a corporation was not a "citizen" of a state for diversity purposes: "That invisible, intangible, and artifical being, that mere legal entity, a corporation aggregate, is certainly not a citizen; and consequently, cannot sue or be sued in the courts of the United States, unless the

1287 U.S. (3 Cranch) at 267-68.

184 E.g., Owen Equip. \& Erection Co. v. Kroger, 437 U.S. 365, 374-75 (1978) (joint tortfeasors).

186 E.g., State Farm Fire \& Casualty Co. v. Tashire, 386 U.S. 523, 530-31 (1967) (interpleader).

196 As it was asserted to be, for example, in Shields v. Barrow, 58 U.S. (17 How.) 130,

145 (1855) (Curtis, J.).

1879 U.S. (5 Cranch) 61, 61 (1809).

18s Id.

18817 U.S. (4 Wheat.) 316 (1819).

19022 U.S. (9 Wheat.) 737 (1824).

1919 U.S. (5 Cranch) at 91. 
rights of the members, in this respect, can be exercised in their corporate name."102 This meant, when taken with the complete diversity requirement just announced in Strawbridge, ${ }^{193}$ that a corporation could not sue if any of its "members" was a cocitizen of the defendant ${ }^{104}-\mathrm{a}$ circumstance that became increasingly likely with the growth of nationwide businesses. ${ }^{195}$

For this important conclusion Marshall gave neither precedent nor argument, and a later Court would argue that a corporation was a "citizen" in the relevant respects: it had power to contract and to sue, and it could be the victim or beneficiary of state court bias. ${ }^{108}$ Moreover, elsewhere in the same opinion Marshall himself cited British examples holding corporations to be "inhabitants" for assessment purposes without regard to the residence of their members. ${ }^{107}$ Perhaps he thought the term "Citizen" required flesh and blood as a simple dictionary matter, ${ }^{108}$ though later cases were to hold that corporations were "citizens" for a variety of statutory

108 Id. at 86.

193 See supra notes $181-83$ and accompanying tert.

194 It had been 80 argued at 9 U.S. (5 Cranch) at 77, 83.

108 It is not clear whether "members" referred to the shareholders, the officers, the directors, or all of them. See Comment, Limited Partnerships and Federal Diversity Jurisdiction, 45 U. CHI. L. Rev. 384, 405-06 (1978); see also Rundle v. Delaware \& Raritan Canal Co., 55 U.S. (14 How.) 79, 94 (1852 Term) (separate opinion of Catron, J.). Justice Washington read "members" to include all "corporators," and he lamented that Deveaux meant that very few corporations can enjoy the privilege of suing, or being sued, in the Courts of the United States, . . . since it can seldom happen, we presume, but that some of their members reside in other states than that in which the business of the corporate body is transacted, and in which the suit is brought.

Kirkpatrick v. White, 4 Wash. C.C. 595, 599-600 (C.C.D. PE. 1826). Charles Warren, agreeing that Deveaux referred to shareholders, argued that "Marshall and everybody else knew" the allegation that the Bank's "company" were Pennsylvanians was "a pure fiction": "a majority of the stockholders of the Bank of the United States were British citizens and aliens or else citizens of other States than Pennsylvania . . . ." Warren, Corporations and Diversity of Citizenship, 19 VA. L. Rzv. 661, 666 (1933).

19 Marshall v. Baltimore \& O.R.R., 57 U.S. (16 How.) 314, 329 (1854); Louisville, C. \& C.R.R. v. Letson, 43 U.S. (2 How.) 497,558 (1844). See also the argument of counsel in a companion case to Deveaux:

If there was a probability that an individual citizen of a state could influence the state courts in his favor, how much stronger is the probability that they could be influenced in favor of a powerful moneyed institution, which might be composed of the most influential characters in the state.

Hope Ins. Co. v. Boardman, 9 U.S. (5 Cranch) 57, 60 (1809) (Mr. Adams).

197 9 U.S. (5 Cranch) at 88-90.

106 See Marshall v. Baltimore \& O.R.R., 57 U.S. (16 How.) 314, 351 (1854) (Campbell, J., dissenting); Rundle v. Delaware \& Raritan Canal Co., 55 U.S. (14 How.) 79, 97-98 (1852 Term) (Daniel, J., dissenting); McGovney, A Supreme Court Fiction, 56 HARv. L. Rev. 853, 874 (1943). 
purposes" as well as "Person[s]" within such provisions as the due process clause. ${ }^{200}$ Perhaps he was thinking ahead in light of his conclusion in Hepburn v. Ellzey that the Framers had used words consistently throughout the Constitution: ${ }^{201}$ if a corporation was a "citizen" within article III, the privileges and immunities clause ${ }^{202}$ might give foreign corporations an advantage by placing them "on a parity with individual citizens," "20s "free of such supervision and control as the state might think it requisite to exercise over its own corporations." limit on jurisdiction; within less than fifty years Marshall's successors were to treat the state of incorporation as decisive. ${ }^{20 s}$

${ }^{200}$ E.g., United States v. Northwestern Express Co., 164 U.S. 686 (1897) (compensation for property of "citizens" taken or destroyed by Indians).

${ }^{200}$ E.g., Kentucky Fin. Corp. v. Paramount Auto Exch. Corp., 262 U.S. 544, 550 (1923) (construing U.S. CoNsT, amend. XIV, \& 1).

${ }^{201}$ See supra note 170 and accompanying text. But see Green, Corporations as Persons, Citizens, and Possessors of Liberty, 94 U. PA. L. REv. 202, 205-06 (1946):

As to each grant of power the question is whether corporations possess the characteristics that bring them within the purposes which the terms of the grant manifest intent to accomplish. That a corporation is neither a person nor a citizen within the meaning of a statute about making wills, voting at elections, or being naturalized, has little bearing on the question whether it is a person or a citizen within the meaning of a provision prescribing the jurisdiction of courts for the enforcement of rights which the corporation possesses and of duties which it owes.

${ }^{202}$ U. S. Const. art. IV, \$ 2, para. 1.

202 G. Henderson, The Position of Foreign Corporations in American ConstituTMONAL LAW 56-57 (1918).

206 Green, supra note 201, at 228. See Bank of Augusta v. Earle, 38 U.S. (13 Pet.) 519, 586 (1839) (refusing to apply Deveaux to the privileges and immunities clause); Paul v. Virginia, 75 U.S. (8 Wall.) 168, 177-82 (1869) (holding a corporation not a "Citizen" within article IV). See also McGovney, supra note 198, at 888, arguing on the basis of Bank of Augusta that if, as the Court declared in Marshall v. Baltimore \& O.R.R., 57 U.S. (16 How.) 314, 326 (1854), "the reason for diverse citizenship jurisdiction was to protect privileges given by Article IV . . . the conclusion should have been that it was not intended to include suits by or against corporations." Compare Chief Justice Taney's use of arguments based on the privileges and immunities clause to support the conclusion that blacks could not be "Citizens" for diversity purposes. Scott v. Sandford, 60 U.S. (19 How.) 393, 417-18, 422-23 (1857).

Counsel in a companion case to Deveaux had anticipated this problem and asserted that the term "Citizen" "has different meanings in different parts of the constitution." Hope Ins. Co. v. Boardman, 9 U.S. (5 Cranch) 57, 59 (1809) (Mr. Adams). In Bank of Augusta itself, the Court would in fact refuse to apply to the privileges and immunities clause $D e-$ veaux's other conclusion that the transaction could be viewed as one by persons comprising the corporation: "[I]n that case, the court confined its decision, in express terms, to a question of jurisdiction . . . ." 38 U.S. (13 Pet.) at 585. See also G. Henderson, supra note 203, at 180-81; Green, supra note 201, at 230.

${ }^{205}$ See cases cited supra note 196. In Louisville, C. \& C.R.R. v. Letson, 43 U.S. (2 How.) 497, 555 (1844), Justice Wayne said that Marshall himself had "repeatedly expressed regret" at the restrictive interpretations he had rendered in Deveaux and Strawbridge. Story wrote in 1844 that Marshall had come to think a corporation was a citizen and that 
What is often overlooked is that the limiting language of $\mathrm{De}$ veaux was unnecessary to the result, because the Court upheld jurisdiction. Indeed in Deveaux itself no one had argued that the Bank was a citizen of any state, and it would have been difficult to do so because it was a federal corporation. As counsel had said, the issue was "whether, by becoming members of the corporation, the individuals who compose it lose, in their corporate affairs, those privileges which as individuals they possessed before?"200 Marshall's answer, once again equating the statutory and the constitutional language, was persuasive: the reason for diversity jurisdiction was the apprehension that state courts might not "administer justice as impartially as those of the nation" to parties from outside the state, ${ }^{207}$ and outsiders "are not less susceptible of these apprehensions . . . because they are allowed to sue by a corporate name."208 The methodological contrast with cases like Strawbridge is noteworthy. Instead of stating his bare conclusion, Marshall reasoned convincingly from the assumed purpose of the diversity clause. ${ }^{209}$

"[t]his was always Judge Washington's opinion." Letter from Joseph Story to James Kent (Aug. 31, 1844), reprinted in 2 LufE \& LETTERs of JosEpH STORY 469 (W. Story ed. 1851). For doubts as to the accuracy of these reports, see McGovney, supra note 198, at 877-78 ("In another instance-and why not in this one?-Mr. Justice Story was a false reporter of the 'real opinion' of the deceased Chief Justice.") (citing New York v. Miln, 36 U.S. (11 Pet.) 102, 161 (1837)). It is clear enough that Justice Washington "regret[ted]" that a corporation was not itself treated as a citizen, Kirkpatrick v. White, 4 Wash. C.C. 595, 599 (C.C.D. Pa. 1826), but it is less clear that he thought Deveaux had misinterpreted the law.

3069 U.S. (5 Cranch) at 79 (Mr. Harper). A companion case in which the defendant was described simply as a Rhode Island corporation was ordered dismissed on the authority of Deveaux. Hope Ins. Co. v. Boardman, 9 U.S. (5 Cranch) 57, 61 (1809).

2079 U.S. (5 Cranch) at 87. Marshall cited no authority to support this conclusion, but the possibility of local bias had been given as a reason for diversity jurisdiction both in The Federalist No. 80, supra note 56, at 476-78 (A. Hamilton), and in the ratifying conventions, e.g., 3 Eulior's DeBatzs, supra note 69, at 144 (Mr. Davie of North Carolina). See generally Friendly, The Historic Basis of Diversity Jurisdiction, 41 HARv. L. REv. 483 (1928).

2089 U.S. (5 Cranch) at 87. This line of argument seems to suggest one reason he thought the corporation itself was not a citizen: the members were real parties in interest, and it was their citizenship rather than the place of incorporation that determined whether there was a risk of bias.

Justice Daniel was later to criticize this part of the Deveaux opinion on the ground that it ignored the legal personality of the corporation; the individual members were not parties. Rundle v. Delaware \& Raritan Canal Co., 55 U.S. (14 How.) 79, 99-100 (1852 Term) (dissenting opinion). But see McGovney, supra note 198, at 867-69 (concluding that instances in which courts had pierced the corporate veil were "too numerous to permit anyone to say that resort by the Court to this way of thinking in solving the jurisdictional problem in the Deveaux case was wrong").

sos 9 U.S. (5 Cranch) at 89. The report reveals no dissent, but Justice Johnson, sitting on circuit below, had ruled there was no jurisdiction: "As a suit in right of a corporation can never be maintained by the individuals who compose it, . . . how is the citizenship of the 
Deveaux is interesting as well for the further insight it affords into Marshall's view of precedent. The Court had entertained diversity cases involving corporations in the past, and that fact was entitled to "much weight, as they show that this point neither occurred to the bar or the bench." ${ }^{220}$ Nevertheless, despite the argument that the Court had had a duty in those cases to raise jurisdictional problems on its own motion, 211 Marshall declined to treat them "as authority; for they were made without considering this particular point."12 This seems to strike an appropriate middle course between his earlier contradictory treatment of similar precedents as either binding ${ }^{313}$ or irrelevant. ${ }^{314}$

\section{Hodgson v. Bowerbank}

The plaintiffs were British citizens; the defendants were described as "late of the district of Maryland,"21s but their present citizenship was not averred. Jurisdiction was challenged in the Supreme Court, and Marshall found it wanting: "Turn to the article of the constitution of the United States, for the statute cannot extend the jurisdiction beyond the limits of the constitution."116

The statute purported to give jurisdiction of "all" civil suits in which "an alien is a party," "between a state, or the citizens thereof, and foreign states, citizens or subjects."118 To read Hodgson one might think the issue was one of first impression, but the Court had already cut the statute down to constitutional size nine years earlier in Mossman $v$. Higginson..$^{219}$ Today we would expect the Court to strengthen its

individuals of the corporate body even to be brought into question . . . ?" 2 F. Cas. 692, 693 (No. 916) (C.C.D. Ga. 1808).

2109 U.S. (5 Cranch) at 88.

211 Id. at 70 (Mr. Binney).

212 Id. at 88.

${ }^{213}$ E.g., Ex parte Bollman, 7 U.S. (3 Cranch) 159 (1805). See supra note 155 and accompanying text.

214 E.g., United States v. More, 8 U.S. (4 Cranch) 75 (1807). See supra notes 130-44 and accompanying text.

2139 U.S. (5 Cranch) 303, 303 (1809).

218 Id. at 304.

217 Judiciary Act of 1789 , ch. 20, $\$ 11,1$ Stat. 73, 78 (current version at 28 U.S.C. $\$ 1332$ (1976)).

${ }_{218}$ U.S. Const. art. III, \& 2, para. 1.

210 4 U.S. (4 Dall.) 12 (1800). See Currie, supra note 1, at 851-52, for discussion of the merits of the issue. Both HART \& WECHsLER, supra note 41, at 417, and C. WRIGHT, supra note 46 , at $93 \&$ n.10, declare that Hodgson held the alien-a-party provision unconstitutional. For the contrary view, see Mahoney, A Historical Note on Hodgson u. Bowerbank, 49 U. ChI. L. REv. 725 (1982). It is clear that Mossman, at least, was based upon a narrow 
conclusion by citing such a square precedent. But precedent, while not wholly foreign to Marshall's opinions, was seldom prominent there. Very likely the explanation for the omission is that the point was obvious and Marshall's resolution extemporaneous; it is not even labelled an opinion of the Court. ${ }^{220}$ An alternative possibility is that he did not know the issue had previously been resolved, for he was not on the Court when Mossman was decided, and the indexing of decisions seems to have been considerably less thorough than it is today. 221

The cases so far considered not only are related by subject matter; they also constitute nearly the entire constitutional output of the Court between 1801 and 1810.222 Only in Marbury and in

interpretation of the statute, which Mahoney shows was consistent with the understanding of Oliver Ellsworth, who drafted the provision. Id. at 731-32 (quoting a letter from Oliver) Ellsworth to Richard Law (Apr. 30, 1789), reprinted in W. BROwN, ThE LIfE OF Ourver EuLSWORTH 188-89 (1905)).

${ }^{230}$ See Mahoney, supra note 219 , at 739.

${ }^{231}$ A perusal of J.G. Marvin, Legal Bibliography (Philadelphia 1847), discloses publication of digests of Supreme Court decisions by John Anthon in 1813-1816, by Supreme Court Reporter Henry Wheaton in 1821 and 1829, and by Richard S. Coxe in 1829. All of these compilations appeared after Hodgson. I am indebted for this information to Richard L. Bowler, former reference librarian at the University of Chicago Law School. See also the complaint of William Cranch, in offering the first volume of his Reports, that "[m]uch of th[e] uncertainty of the law . . may be attributed to the want of American reports." 5 U.S. (1 Cranch) i, iii (1803). The volume containing Mossman had finally been published in 1807 .

${ }^{222}$ Four other decisions of this period deserve brief mention for the sake of completeness. Two dealt with federal jurisdiction. In Owings v. Norwood's Lessee, 9 U.S. (5 Cranch) 344, 344 (1809), Marshall reaffirmed that article III was a limitation on Congress's power by observing in dictum that section 25 of the Judiciary Act of 1789 , ch. $20, \S 25,1$ Stat. 73, 8387 (current version at 28 U.S.C. $\$ 1257$ (1976)), could not extend jurisdiction beyond the cases enumerated in that article. He also held, without invoking the Constitution, that a litigant could not assert the rights of third parties. 9 U.S. (5 Cranch) at 348.

The second jurisdictional decision was United States v. Peters, 9 U.S. (5 Cranch) 115 (1809), a highly confusing opinion allowing an action against administrators of a state treasurer despite the eleventh amendment. This case was later relied on as establishing an important point with respect to sovereign immunity, but because of its cryptic obscurity it seems preferable to discuss it below in connection with the more comprehensible opinion in Osborn v. Bank of the United States, 22 U.S. (9 Wheat.) 738, 795 (1824). See infra note 323 and accompanying text.

Finally, there were two substantive decisions of considerable innate interest, though of little lasting significance, perhaps because of their cryptic style. United States v. Fisher, 6 U.S. (2 Cranch) 358, 395 (1805), prefigured McCulloch v. Maryland, 17 U.S. (4 Wheat.) 316 (1819), by giving a broad interpretation to the necessary and proper clause, U.S. CoNST. art. $\mathrm{I}, \S 1$, cl. 18; this case will be discussed with $\mathrm{McCulloch}$ in a subsequent article. The Flying Fish, 6 U.S. (2 Cranch) 170 (1804), anticipated the famous Steel Seizure Case (Youngstown Sheet \& Tube Co. v. Sawyer, 343 U.S. 579 (1952)), in its bare conclusion that Congress might forbid the President to seize vessels as a means of law enforcement, notwithstanding the command in U.S. CoNST. art. II, $\S 3$, that he "take Care that the Laws be faithfully 
Deveaux were there opinions of any length on the constitutional questions. Deveaux shows that Marshall could argue persuasively from constitutional purposes; Marbury illustrates among other things his tendency to conclude that the Constitution means what he would like it to mean. The other opinions demonstrate that during this period Marshall, like his predecessors, considered it unnecessary to devote much effort to explaining every constitutional decision. Several of his pronouncements can be characterized as cavalier. Strawbridge is conclusory; Hepburn is highly literalistic; Bollman resolved a critical ambiguity in the governing standard without acknowledging its existence. In some cases this nonchalance may have been related to the relative unimportance of the issue, but the immediate controversy in Bollman was of considerable political significance; one might have expected the Court to be more careful. Finally, these early cases are of considerable interest for their efforts to establish a doctrine of precedent, and in that regard they run the gamut from unquestioning adherence to legislative practice and judicial "acquiescence" in Stuart to Marshall's failure to invoke precedential support in Marbury or Hodgson and Johnson's frank avowal in Bollman that no judicial precedent is beyond correction.

\section{Review of State Courts; Fedreral Questions; AND SOVEREIGN IMMUNITY}

\section{A. Martin v. Hunter's Lessee}

Virginia claimed to have escheated land owned by an enemy alien. In an earlier opinion, the Supreme Court had held the land had not been taken before a 1794 treaty confirming British titles. ${ }^{235}$ The state court refused to obey the Supreme Court's mandate, arguing that Congress had no power to authorize federal review of state court decisions. ${ }^{234}$ The Supreme Court, in 1816, reversed.225

Marshall, who had once appeared as counsel in the controversy and whose family had an interest in the lands, ${ }^{238}$ did not sit; Story wrote the Court's lengthy opinion. He relied in part upon

executed."

${ }^{233}$ Fairfax's Devisee v. Hunter's Lessee, 11 U.S. (7 Cranch) 603, 625-27 (1813).

234 Hunter v. Martin, 18 Va. (4 Munf.) 1, 7 (1813).

22x 14 U.S. (1 Wheat.) 304 (1816).

230 For the background of the controversy, see 4 A. BEVERmge, supra note 11, at 145-67; 2 W. CRosskgY, supra note 55, at 785-817; G. HAskins \& H. JoHNSON, supra note 24, at 35765; 1 C. WARREN, supra note 23 , at $442-53$. 
established practice, and with considerable force: review of state courts had been authorized by the First Congress, which contained "men who had acted a principal part in framing, supporting or opposing [the] constitution";227 it had been exercised for nearly thirty years without objection; ${ }^{228}$ it had been avowed by friends and admitted by enemies of the proposed Constitution "both in and out of the state conventions"; it had even been unmistakably authorized by the relatively feeble Articles of Confederation. ${ }^{229}$ In contrast to the opinion in Stuart $v$. Laird, ${ }^{230}$ however, Story's opinion did not treat practice as decisive; in accord with the opinion in Marbury $v$. Madison, ${ }^{231}$ he recognized the Court's obligation to decide the question on its merits. ${ }^{232}$

Story attempted to make hay out of the language of article III: federal judicial power extends to "all" cases arising under federal law and therefore includes those decided by state courts. ${ }^{233}$ The Virginia court had anticipated this ploy and destroyed it: no one would hold the Supreme Court could review judgments of foreign courts interpreting federal law. ${ }^{234}$

29714 U.S. (1 Wheat.) at 351. But see the opinion of Justice Roane in the court below: I had not expected that they would have been quoted, to prove it constitutional. Their opinion was already manifest, in the act itself, and it required the opinions of others, at least to corroborate and support it. . . . [L]ittle credit is certainly due to the construction of those, who were parties to the conflict ....

$18 \mathrm{Va}$ (4 Munf.) at 28-29.

$2 x 314$ U.S. (1 Wheat.) at 351-52. It had also, though Story did not say so, been acknowledged by the Virginia Republican and judge St. George Tucker in 1803. See 1 Tucker's Appendix to Blackstone, supra note 86, at 183-84.

228 See 14 U.S. (1 Wheat.) at 345, invoking the provision in ARTICLES of Confederation art. 9, para. 1, establishing "courts for receiving and determining, finally, appeals in all cases of captures": "It is remarkable, that no power was given to entertain original jurisdiction in such cases; and consequently, the appellate power (although not so expressed in terms) was altogether to be exercised in revising the decisions of state tribunals" (emphasis added). Not cited by Story was Penhallow v. Doane's Administrators, 3 U.S. (3 Dall.) 54, 107, 115-16 (1795), where the Court ordered enforcement of a decree of the capture court and individual Justices affirmed the constitutionality of its power over state court judgments. Id. at 119-20 (Cushing, J.). See Currie, supra note 1, at 875-78.

${ }^{280} 5$ U.S. (1 Cranch) 299 (1803); see supra notes 102-29 and accompanying text.

2315 U.S. (1 Cranch) 137, 154 (1803); see supra notes 39-101 and accompanying text.

28ะ 14 U.S. (1 Wheat.) at 323.

${ }^{28 s}$ Id. at 338-39. ("The appellate power is not limited by the terms of the third article to any particular courts. . . It is the case, then, and not the court, that gives the jurisdiction.") (emphasis added). Hamilton had made the same point in The FEderalist No. 82, supra note 56, at 493-94. Story did not cite him, though counsel had done so. 14 U.S. (1 Wheat.) at 313 (Mr. Jones). Spencer Roane in the court below had dismissed The Federalist as "a mere newspaper publication, written in the heat and hurry of the battle, . . . and with a view to ensure [the proposed Constitution's] ratification." $18 \mathrm{Va}$. (4 Munf.) at 27.

284 $18 \mathrm{Va}$. (4 Munf.) at 14 (Cabell, J.) ("But this argument proves too much, and what is utterly inadmissible. It would give appellate jurisdiction, as well over the courts of England 
More compelling was Story's argument that the purposes of article III required that its terms be read to permit Supreme Court review of state judgments. In the first place, "[t]he constitution has presumed ... that state attachments, state prejudices, state jealousies, and state interests, might sometimes obstruct, or control, or be supposed to obstruct or control, the regular administration of justice."23s Moreover,

[j]udges of equal learning and integrity, in different states, might differently interpret the statute, or a treaty of the United States, or even the constitution itself: If there were no revising authority to control these jarring and discordant judgments, ... the laws, the treaties and the constitution of the United States would be different, in different states . . . . [T]he appellate jurisdiction must continue to be the only adequate remedy for such evils. ${ }^{230}$

It was not enough, he continued, that plaintiffs with federal claims could be authorized to sue in federal trial courts. Defendants had federal rights, too, which the Constitution meant to protect. $^{237}$ Removal $^{288}$ was no answer because (contrary to common sense and to Marshall's definition in Marbury ${ }^{239}$ ) it too was an exercise in "appellate" jurisdiction. ${ }^{240}$ Further, removal was an inadequate safeguard. "If state courts should deny the constitutionality of the authority to remove suits from their cognizance, in what manner could they be compelled to relinquish the jurisdiction?"241 Perhaps there would be ways, ${ }^{242}$ but the Court had long since re-

or France, as over the state courts . . . .").

${ }^{228} 14$ U.S. (1 Wheat.) at 347.

228 Id. at 348. Rutledge had expressly stated these purposes in discussing the arisingunder jurisdiction during the Convention. See infra note 246.

23714 U.S. (1 Wheat.) at 348-49.

2se Removal had been invoked by the Virginia court in answer to the argument based on article III's purposes. See $18 \mathrm{Va}$ (4 Munf.) at 15-16 (Cabell, J.).

230 5 U.S. (1 Cranch) 137,175 (1803) ("It is the essential criterion of appellate jurisdiction, that it revises and corrects the proceedings in a cause already instituted, and does not create that cause."). In line with Marshall's reference to causes "already instituted" elsewhere, Story (without citing Marbury) noted that removal "presupposes an exercise of original jurisdiction to have attached elsewhere." 14 U.S. (1 Wheat.) at 349. Yet removal before state court decision would not appear to "revise" or "correct" anything the state court had done, and earlier decisions had emphasized that this was the governing consideration. See Ex parte Bollman, 8 U.S. (4 Cranch) 75, 93, 101 (1807); supra notes 145-59 and accompanying text.

${ }^{240} 14$ U.S. (1 Wheat.) at 349-50.

241 Id. at 350.

242 One is tempted to say by enjoining the state court plaintiff from proceeding. By the time the state court had exhibited its defiance of the removal order by asserting its jurisdic- 
jected the notion that the necessary and proper clause authorized only those means of carrying out federal powers that were indispensable; ${ }^{243}$ it should have sufficed that Supreme Court review was, in the words Marshall was soon to use in McCulloch v. Maryland, ${ }^{244}$ an "appropriate" means "plainly adapted" to the assertion of federal judicial power over federal question cases, and entirely in accord with the "spirit" of the Constitution.245

This reasoning was fully adequate to sustain the Court's jurisdiction. ${ }^{246}$ Yet Story began his opinion with the gratuitous contention that Congress was not only permitted but required to authorize Supreme Court review of state courts. Article III, he argued, was mandatory, for it provided that the judicial power "shall extend to all Cases" arising under federal law and that it "shall be vested" in federal courts. ${ }^{247}$ The power to make "Exceptions" to the Supreme Court's appellate jurisdiction, he acknowledged, gave Congress considerable discretion as to which federal courts should be given jurisdiction; but "the whole judicial power of the United States should be, at all times, vested, either in an original or appellate form, in some courts created under its authority."248 Federal questions were bound to arise in state court proceedings, and the supremacy clause required state courts to decide them; the federal power could reach these cases only by appellate review. ${ }^{249}$ In addition, he argued, Congress was required to create inferior federal courts to hear any article III cases over which neither the Supreme Court nor a state court had original jurisdiction, for the federal

tion, however, the federal injunctive proceeding might well be deemed appellate under Ex parte Bollman on the ground that it entailed review of the state's jurisdictional decision. See supra notes 145-59 and accompanying text.

243 United States v. Fisher, 6 U.S. (2 Cranch) 358 (1805). See supra note 222.

2417 U.S. (4 Wheat.) 316 (1819).

${ }^{243}$ Id. at 421. Justice Johnson, who had dissented on the merits when Martin was first before the Court, 11 U.S. ( 7 Cranch) at $628-32$, this time wrote a long concurrence that emphasized that the Court was not issuing a mandatory order to the state court, but added little to Story's reasoning, 14 U.S. (1 Wheat.) at 362-82.

${ }^{216}$ Moreover, as Professor Gunther has noted, "an expectation of Supreme Court review of state court judgments runs through the Constitutional Convention debates." G. GuNTHER, supra note 26 , at 36 . When Rutledge moved to eliminate a provision establishing inferior federal courts, he did so with the argument that "the right of appeal to the supreme national tribunal" was "sufficient to secure the national rights \& uniformity of Judgmts"; Madison, opposing the motion, did not dispute the availability of Supreme Court review, but argued it was an inadequate remedy. 2 ConvenTION Records, supra note 69, at 124.

${ }^{207} 14$ U.S. (1 Wheat.) at 331 (quoting U.S. CoNst. art. III, § 2, para. 1) (emphasis added).

218 Id.

249 Id. at 341-42. 


\section{judicial power would otherwise not reach these cases at all. ${ }^{250}$} None of this was necessary to the result, for Congress had conferred appellate jurisdiction on the Supreme Court, and the necessity of creating district courts had nothing to do with the case at all. Story's thesis that the entire judicial power must be vested somewhere has not been very popular, though it was picked up as an alternative holding by one modern court of appeals. ${ }^{251}$ It does have the virtue of reconciling all the apparently inconsistent words of article III, but it was contrary to Supreme Court precedent, ${ }^{262}$

${ }^{250}$ Id. at 330-31. Story spoke in particular of "that jurisdiction which, under the constitution, is exclusively vested in the United States," id. at 331, and elsewhere he suggested that Congress could not allow criminal cases or some maritime cases to be decided by state courts, id. at 336-37. The Federalist had flatly taken the position that the Constitution did not make federal jurisdiction exclusive, THE Federalist No. 82, supra note 56, at 492 (A. Hamilton), and Congress had acted on that assumption in 1789, Judiciary Act of 1789, ch. $20, \S 11,1$ Stat. 73,78 (current version at 28 U.S.C. $\$ 1332$ (a) (1976)). With respect to criminal cases, Story's dictum was repudiated by Justice Washington's opinion in Houston v. Moore, 18 U.S. (5 Wheat.) 1, 12 (1820); see infra notes 336-53 and accompanying text. For elaboration of Story's views on the exclusivity of federal admiralty power, see 3 J. STORY, supra note 109, at 533-34 n.3 (rejecting contemporary views that federal jurisdiction was exclusive even in cases over which common law courts had previously exercised concurrent authority).

${ }^{281}$ Eisentrager v. Forrestal, 174 F.2d 961, 966 (D.C. Cir. 1949). See also 1 W. CRosskey, supra note 55 , at $610-18$.

${ }^{233}$ Turner v. Bank of N. Am., 4 U.S. (4 Dall.) 8 (1799) (upholding the assignee clause described infra note 253). See Currie, supra note 1, at 849-51.

See also United States v. Hudson, 11 U.S. (7 Cranch) 32, 33 (1812) (Johnson, J.) (denying the power of federal courts to punish common law crimes: "[T]he power which Congress possess to create courts of inferior jurisdiction, necessarily implies the power to limit the jurisdiction of those courts to particular objects . . .."). Whether there was really an absence of jurisdiction in Hudson is not so clear, for the Judiciary Act of 1789 gave the circuit courts "cognizance of all crimes and offences cognizable under the authority of the United States." Ch. 20, $\$ 11,1$ Stat. 73, 79 (repealed 1911). For current limitations on district court jurisdiction, see 28 U.S.C. $\$ \S 1332,1359$ (1976). Justice Story was to argue even after Hudson that this provision both gave the courts jurisdiction over nonstatutory crimes and empowered them to define those crimes according to the common law. United States v. Coolidge, 25 F. Cas. 619 (No. 14,857) (C.C.D. Mass. 1813). Hudson, not mentioning section 11, had appeared to deny both jurisdiction and lawmaking authority. See 11 U.S. (7 Cranch) at 34 ("The legislative authority of the Union must First make an act a crime, affix a punishment to it, and declare the court that shall have jurisdiction of the offence.").

Although Hudson was a libel case, Coolidge was maritime, and Story distinguished Hudson by arguing that in admiralty cases it was clear that judge-made law had always been acceptable. 25 F. Cas. at 621 . In the Supreme Court, however, the government declined to make this argument, and the Court held that under the circumstances it would follow Hudson. United States v. Coolidge, 14 U.S. (1 Wheat.) 415, 416-17 (1816) (Johnson, J.). For approval of Story's distinction, see P. DuPonceau, A Dissertation on the Nature and ExTRNT OF the JURISDiction of the Courts of the UnItBd States 9-11 (Philadelphia 1824 \& reprint 1972).

Although Hudson and Coolidge seem to have been based upon a lack of jurisdiction, Johnson's additional suggestion that only Congress may create substantive offenses was an important precursor of Erie R.R. v. Tompkins, 304 U.S. 64 (1938), which held the creation 
which Story did not cite, as well as to consistent congressional practice, ${ }^{253}$ which in the same opinion he insisted was entitled to considerable deference. ${ }^{254}$ Finally, the strongest argument against giving a natural reading to the ostensibly unlimited discretion of Congress to limit federal jurisdiction is Marbury's principle that the courts were intended to enforce constitutional limits on legislative power. ${ }^{25 s}$ Story's interpretation poorly comports with that principle, for it outlaws such minor caseload adjustments as the jurisdictional amount while allowing Congress to evade any substantial check by vesting sole power over important constitutional questions in a single lower court selected for the complaisance of its judges. ${ }^{250}$

The contrast between the lengthy and intricate Martin opinion and the numerous curt and conclusory Marshall pronounce-

of federal common law in diversity cases in the absence of statutory authorization an invasion of "rights . . . reserved by the Constitution to the several states," id. at 80 . It is interesting that Johnson stated in Hudson that he spoke for "the majority of this court," 11 U.S. (7 Cranch) at 33 , for no dissent was recorded.

${ }^{283}$ The Supreme Court has never had appellate power over state court judgments in diversity cases, yet the Judiciary Act of 1789 excluded many such cases from inferior federal courts as well by the assignee clause, the jurisdictional amount, and the requirement that one party be a citizen of the forum state. Ch. 20, $\$ 11,1$ Stat. 73, 78-79 (current provisions at 28 U.S.C. $\$ \S 1332,1359$ (1976)). Story did suggest that diversity cases might be distinguishable, despite the mandatory "shall," because in extending judicial power to them article III omitted the word "all." 14 U.S. (1 Wheat.) at 333-36. Contra, 1 W. Crosskey, supra note 55, at 614-15. Yet even with respect to federal question cases the Judiciary Act of 1789 failed this test, for it created no federal question jurisdiction in federal trial courts, and Supreme Court review was limited among other things to cases in which the state court had denied a federal right. Ch. $20, \S 25,1$ Stat. 73,85 (current provisions at 28 U.S.C. $\$ \S 1257$, 1331 (1976)).

266 See supra note 227 and accompanying text.

${ }^{265}$ See supra notes 95-100 and accompanying text.

2se The final question confronted in Martin was whether the Court had jurisdiction not only to construe the treaty but also to determine whether escheat had been accomplished before the treaty took effect. It held it had: the statute gave it power to decide upon the "title" claimed under federal law, and a "preliminary inquiry" into the title was unavoidable before the Court could decide whether it was protected by the treaty. 14 U.S. (1 Wheat.) at 358. This argument seems disingenuous. As a matter of logic, the state court's threshold determination of its own law could certainly have been accepted, and the Court was later to hold that the purposes of uniformity and protection of federal rights, which Martin had identified as underlying article III, did not generally require the Supreme Court to review state law questions in state court cases. Murdock v. City of Memphis, 87 U.S. (20 Wall.) 590, 621 (1875). Yet Story identified a pressing reason why those purposes did so require whenever a state law finding was a precondition to upholding a federal right: absent the power to review such determinations, the appellate jurisdiction could be "evaded at pleasure." 14 U.S. (1 Wheat.) at 357. See 1 W. CRosskey, supra note 55, at $615 ; 2$ id. at 809-12 (arguing that as a matter of statutory construction Story's interpretation was questionable but that Congress's attempt to limit the Court to the decision of federal questions was unconstitutional). 
ments previously considered is striking, and it may lead us to wish Story had been allorved to write more constitutional opinions. For apart from Story's strained excursion into the question whether Congress could refuse to grant jurisdiction (which is reminiscent of Marshall's excesses in Marbury), Martin is in many respects both a model opinion and a very modern one. It takes the constitutional question seriously, even though the answer may not be difficult; it marshalls convincing arguments based upon the purposes of the provision it is construing; and it supports them with a balanced and persuasive use of historical practice.

Differences in style between Marshall and Story are confirmed by opinions in other cases, ${ }^{257}$ but they do not provide a complete explanation of the contrast between Martin and the early Marshall opinions. For one thing, Story could be cavalier and conclusory himself, as we shall soon see. ${ }^{258}$ For another, Martin, like Marbury, was a case of considerable political significance; it was important for the Court to write a real explanation. Finally, constitutional opinion writing in general had undergone a marked change since Marshall's early opinions. The extensive Martin opinion, while more persuasive than many, was characteristic of a new style that Marshall himself had adopted in the contract clause cases beginning in $1810 .^{259}$

\section{B. Cohens v. Virginia}

Convicted in state court for selling lottery tickets in Virginia, the brothers Cohen defended on the basis of an Act of Congress authorizing the local government of the District of Columbia to establish a lottery. Affirming on the ground that the law did not purport to authorize ticket sales outside the District, ${ }^{280}$ Marshall in

${ }^{267}$ Compare the opinions of the two Justices in Trustees of Dartmouth College v. Woodward, 17 U.S. (4 Wheat.) 518, 624-54 (1819) (Marshall, C.J.), id. at 661-713 (Story, J.).

2ss See, e.g., infra notes $373-95$ and accompanying tert (discussing The Thomas Jefferson).

258 I discuss the contract clause cases in a forthcoming article. No doubt this change in style had something to do with the increased importance of the cases that reached the Court after 1810. Although there were to be sure continuing examples of perfunctory disposition of constitutional questions, that was no longer the prevailing mode after 1810.

For the suggestion that Marshall may not have been "as remote from the [Martin] cases as his self-disqualification suggests," see G. DUNNB, JUsTice Joskph STORY AND THs RISE OP THE SUPREME CoURT 135-36 (1970) (concluding that "the authorship seems a joint one").

26019 U.S. (6 Wheat.) 264, 440-48 (1821). In reaching this conclusion Marshall announced an important rule of statutory construction based on concerns of federalism: "To interfere with the penal laws of a state, where they are not levelled against the legitimate 
1821 sustained the Court's appellate jurisdiction over a variety of interesting constitutional objections. ${ }^{261}$

Marshall began, as in Marbury $v$. Madison, by predisposing the reader to his result. Assuming that the state court had denied a federal right, Marshall argued that Virginia was claiming that "it is not in the power of the government to apply a corrective . . . [;] that the nation does not possess a department capable of restraining, peaceably, and by authority of law, any attempts which may be made, by a part, against the legitimate powers of the whole."262 Surely the Constitution was not so defective as to provide no remedy for its own violation. ${ }^{263}$ It remained only to find

powers of the Union, but have for their sole object the internal government of the country, is a very serious measure, which congress cannot be supposed to adopt lightly or inconsiderately." Id. at 443. Cf. United States v. Bass, 404 U.S. 336, 349 (1971) ("Unless Congress conveys its purpose clearly, it will not be deemed to have significantly changed the federalstate balance.").

${ }^{201}$ In passing on its jurisdiction the Court also held, essentially on the basis of the constitutional text alone, that an Act of Congress passed pursuant to the power "to exercise exclusive Legislation" over the District of Columbia, U.S. ConsT. art. I, \& 8, cl. 17, was a "law[] of the United States" for purposes of both section 25 of the Judiciary Act of 1789, ch. $20, \S 25,1$ Stat. 73, 85 (current version at 28 U.S.C. \& 1257 (1976)), and the supremacy clause, U.S. Const. art. VI, para. 2. Neither point was obvious. Indeed, the Court was to hold the contrary in the context of the appealability of the judgment of a District of Columbia court in Key v. Doyle, 434 U.S. 59, 67-68 (1977); and Marshall chose not to refer to earlier authority on the status of the District, see supra notes 130-44, 164-78, and accompanying text (discussing United States v. More and Hepburn v. Ellzey); Loughborough v. Blake, 18 U.S. (5 Wheat.) 317 (1820). Marshall ignored completely the further argument that the case arose not under the statute authorizing the local legislature to create a lottery but under the local legislation actually doing so. 19 U.S. (6 Wheat.) at 292-93 (Mr. Barbour). Cf. Ex parte Bransford, 310 U.S. 354, 359 (1940) (attack of administrative action taken pursuant to statute not attack on "statute" for purposes of three-judge court requirement).

It was in the context of whether laws passed under the District power were "laws of the United States" that Marshall chose to declare, largely on the basis of examples derived from statute, that a law passed under that power could be made to "operate without the district" if that was "necessary to its complete and effectual execution." 19 U.S. (6 Wheat.) at 426-29. The relevance of this conclusion to the jurisdictional issue was tangential (counsel had argued that a law applicable only to the District was not a "law[] of the United States," id. at 297), and the Court's finding on the merits that Congress had not attempted to authorize ticket sales in Virginia made it unnecessary to decide whether it could constitutionally have done so. The question of the extraterritorial reach of the District of Columbia power was to be debated again in National Mut. Ins. Co. v. Tidewater Transfer Co., 337 U.S. 582 (1949).

${ }^{262} 19$ U.S. (6 Wheat.) at 377.

26s Marshall also argued that Virginia's position "would prostrate . . . the government and its laws at the feet of every state in the Union," $i d$. at 385, and that "[n]o government ought to be so defective in its organization, as not to contain within itself, the means of securing the execution of its own laws," $i d$. at 387. Marshall's remarks about the relevance of what he termed the "mischievous consequences" of Virginia's position are of interest:

We do not mean to say, that the jurisdiction of the courts of the Union should be construed to be co-extensive with the legislative, merely because it is fit that it should be so; but we mean to say, that this fitness furnishes an argument in construing the 
pegs in the constitutional text on which to hang the foregone conclusion.

One of Virginia's principal arguments was that the appellate jurisdiction extended only to cases coming from lower federal courts. ${ }^{264}$ This contention had been rejected five years earlier after exhaustive discussion in Martin $v$. Hunter's Lessee. ${ }^{205}$ It was remarkable that the state was prepared to devote substantial efforts to rearguing the issue, ${ }^{286}$ and more remarkable still that Marshall took it seriously. Rather than rejecting the argument summarily with a reference to Martin, he wrote ten pages retracing Martin's reasoning, without attribution or noticeable improvement, adding in the last sentence of the section that further observations were unnecessary "because the subject was fully discussed and exhausted in the case of Martin $v$. Hunter."287 This might look like a slap at the faithful Story, whose masterwork was reduced to an offhand reference; but, as Marshall was wont to treat his own

constitution, which ought never to be overlooked, and which is most especially entitled to consideration, when we are inquiring, whether the words of the instrument which purport to establish this principle, shall be contracted for the purpose of destroying it. Id. at 384-85. Compare the treatment of a similar argument from mischievous consequences in Hepburn v. Ellzey, 6 U.S. (2 Cranch) 445, 453 (1805), discussed supra in notes 173-77 and accompanying text.

The importance of the question in Cohens for the balance of federal-state power was recognized by John C. Calhoun, the high priest of states' rights, who placed a high priority on the repeal of section 25: "If the appellate power from the State courts to the United States court provided for by the 25 th Sec. did not exist, the practical consequence would be, that each government would have a negative on the other . . . " Letter from John C. Calhoun to Littleton W. Tazewell (Aug. 25, 1827), quoted in G. GuNTHBR, supra note 26, at 46 n.t. Although this observation supports Marshall's conclusion that a contrary result in Cohens would have imperiled the vitality of the central government, it does not prove he was right in upholding jurisdiction. For as Spencer Roane had said in the Martin controversy, "there is a Charybdis to be avoided, as well as a Scylla; . . . a centripetal, as well as a centrifugal principle, exists in the government." Hunter v. Martin, 18 Va. (4 Munf.) 1, 26 (1815). Indeed events have proved him dead right, and there is as much reason to think the Framers would have been as distressed by the destruction of state rights as by the crippling of federal power. For the view that the Cohens opinion was a response to the secession threat raised in debates over the Missouri Compromise, see 4 A. Beveridge, supra note 11, at 340-66, quoting, among other things, a letter from Marshall to Story (July 13, 1821): " "The attack upon the judiciary is in fact an attack upon the union." "Id. at 365.

26419 U.S. (6 Wheat.) at 312-29 (Mr. Smyth). Barbour, also arguing for the state, noted his continuing disagreement with Martin but forbore to discuss it because "that question had been solemnly decided . . . by this Court . . . ." Id. at 310 n.(a).

${ }^{268} 14$ U.S. (1 Wheat.) 304, 323-52 (1816); see supra notes 225-45 and accompanying text.

260 For a description of the vociferous political agitation in Virginia against the assertion of jurisdiction in Cohens, see 1 C. WARREN, supra note 23, at 547-52.

20719 U.S. (6 Wheat.) at $413-23$. 
precedents the same way, ${ }^{288}$ it seems rather a commentary on his general disdain for reliance on authority.

One significant respect in which Cohens differed from Martin, however, was that it was a criminal proceeding, and Virginia had argued that the article III grant of power over "cases, in Law and Equity"269 limited the jurisdiction to civil matters. ${ }^{270}$ The words certainly did not compel this conclusion, and, as Marshall showed in responding to a different argument, the article's purpose of protecting federal rights was equally applicable to criminal and civil cases. ${ }^{271}$ It is noteworthy, however, that while Marshall devoted ten pages to an issue foreclosed by precedent, he did not respond at all to the new argument that criminal cases were outside the federal question power.

Marshall did address at great length new arguments based upon the fact that in Cohens, in contrast to Martin, the state was a party. The first contention was that this fact deprived the federal courts of jurisdiction altogether because "a sovereign independent state is not suable, except by its own consent."272 The simple answer would have been that nobody was suing Virginia; Virginia was suing the Cohens, and sovereign immunity had never meant that persons charged with crime could not defend themselves by appealing. ${ }^{273}$ Never one to take the easy road if he could establish a broad principle instead, Marshall gave a much more controversial

${ }^{268}$ See, e.g., Trustees of Dartmouth College v. Woodward, 17 U.S. (4 Wheat.) 518 (1819), and McCulloch v. Maryland, 17 U.S. (4 Wheat.) 316 (1819), both to be discussed in a forthcoming article.

${ }^{260}$ U.S. Const. art. III, \& 2, para. 1.

27019 U.S. (6 Wheat.) at 321-23 (Mr. Smyth). The Court was later to hold, as Justice Iredell had already suggested in Chisholm v. Georgia, 2 U.S. (2 Dall.) 419, 431-32 (1793), that its original jurisdiction over "Controversies . . . between a State and Citizens of another State," U.S. CoNST. art. III, § 2, para. 1, was limited to civil cases, in reliance on the tradition that " ' $[t]$ he courts of no country execute the penal laws of another," "Wisconsin $v$. Pelican Ins. Co., 127 U.S. 265, 290 (1888) (quoting Marshall's opinion in The Antelope, 23 U.S. (10 Wheat.) 66, 123 (1825)). Indeed, Marshall hinted at this conclusion in Cohens, 19 U.S. (6 Wheat.) at 398-99; he did not explain why it was not equally true of "Cases . . . arising under" federal law. St. George Tucker had suggested in 1803 a textual basis for the distinction: although " $[t]$ he word cases . . . comprehends . . . all cases, whether civil or criminal, . . . I do not recollect ever to have heard the expression, criminal controversy." 1 Tucker's Appendix to Blackstone, supra note 86, at 420 (emphasis in original).

${ }^{271}$ See infra notes 276-77 and accompanying text.

27219 U.S. (6 Wheat.) at 380 . Marshall was accurately restating the argument of counsel. See id. at 302-09 (Mr. Barbour); id. at 315 (Mr. Smyth).

${ }^{273}$ See Governor of Georgia v. Madrazo, 26 U.S. (1 Pet.) 110, 131 (1828) (Johnson, J., dissenting) ("In England, the king cannot be sued, yet he is daily brought before the appellate court, as a defendant in error. . . . The thing is unavoidable--it is incident to the right of appeal."). Counsel had so argued in Cohens. 19 U.S. (6 Wheat.) at 350 (Mr. Ogden); id. at 366-67 (Mr. Pinkney). See also infra note 319. 
answer with implications far transcending the case: "[T]he judicial power, as originally given, extends to all cases arising under the constitution or a law of the United States, whoever may be the parties."274 Far from excepting cases to which a state was a party, Marshall argued, the words of article III included "all" federal question cases. ${ }^{275}$ Other clauses of the same article explicitly extended the judicial power to many controversies to which a state was a party, ${ }^{278}$ review of "cases where a state shall prosecute an individual who claims the protection of an act of congress" was necessary to "the preservation of the constitution and laws of the United States."

Marshall's broad conclusion that article III embraced "all" federal question cases and his characterization of the issue as one of sovereign immunity suggest he may have been taking a case in which a state was plaintiff as the occasion for asserting that a state could be made a defendant as well. ${ }^{278}$ His reasoning paralleled that employed in Chisholm v. Georgia, ${ }^{279}$ which typically he did not cite, where the Court had held that article III's provision for jurisdiction over "controversies ... . between a State and Citizens of another State"280 included those in which the state was the defendant. ${ }^{281}$ One might have thought the nation's outraged reversal of Chisholm by constitutional amendment would have made for greater caution in extending its repudiated principles to a clause that did not expressly refer to cases in which a state was a party, ${ }^{282}$

${ }^{274} 19$ U.S. (6 Wheat.) at 392.

278 Id. at 382.

278 Id. at 383. This fact, of course, had been used by Virginia as an argument against jurisdiction: when the Framers meant to extend judicial power to cases involving states, they did so expressly. Id. at 303 (Mr. Barbour).

${ }^{277}$ Id. at $387,391$.

278 At another point, Marshall seemed to concede that a citizen could not sue his own state to recover a tax unconstitutionally levied on exports, but his evident reason was that such a case might arise under an implied assumpsit rather than under the Constitution. Id. at 402-03. But cf. Osborn v. Bank of the United States, 22 U.S. (9 Wheat.) 738, 821 (1824); infra notes 299-335 and accompanying text. He did not seem to say that the state was immune from suit.

279 2 U.S. (2 Dall.) 419 (1793).

280 U.S. CoNsT. art. III, § 2, para. 1.

2812 U.S. (2 Dall.) 450-51 (Blair, J.); id. at 465-66 (Wilson, J.); id. at 467-68 (Cushing, J.); id. at 475-77 (Jay, C.J.). Like Chisholm, Cohens ignored both the tradition of sovereign immunity that formed the backdrop of the Constitution and the explicit assurances of several prominent Framers that the Constitution respected that tradition. See Currie, supra note 1 , at 831-39.

${ }^{283}$ See 19 U.S. (6 Wheat.) at 306.07 (Mr. Barbour) (arguing that the reason the eleventh amendment applied only to suits by aliens or citizens of other states was "that it was only to them that the privilege of being parties in a controversy with a state, had been 
or at least would have restrained the Court from applying those principles gratuitously to a case in which the state was not a defendant. ${ }^{283}$

Having found the case within article III, Marshall held it was not forbidden by the eleventh amendment, which excluded from the judicial power "any suit in law or equity, commenced or prosecuted against one of the United States by Citizens of another State." Once again there was an obvious answer, and this time Marshall gave it: there was no allegation that the Cohens were citizens of another state, domestic or foreign. ${ }^{284}$ But Marshall gave this answer only after he had devoted six pages to an alternative ground that, while convincing, was somewhat less obvious. This time the unnecessarily broad ground was the one that Marshall had disdained in connection with article III: the eleventh amendment did not apply because the Cohens had been defendants, not plaintiffs, below. ${ }^{285}$ The writ of error was not an independent "suit" but "a continuation of the same suit, . . . not for the purpose of asserting any claim against the state, but for the purpose of asserting a constitutional defence against a claim made by a state."288

extended in the text of the Constitution"). The explicit reference to states in the applicable provision of article III had been a principal basis of the Chisholm decision.

${ }^{203}$ The implication in Cohens that an unconsenting state could be sued in a federal question case was repudiated in Hans v. Louisana, 134 U.S. 1 (1890).

At one point in the Cohens opinion Marshall announced the "universally received opinion . . . that no suit can be commenced or prosecuted against the United States." 19 U.S. (6 Wheat.) at 411-12. This dictum was cited as establishing the sovereign immunity of the United States by both $3 \mathrm{~J}$. STORY, supra note 109, at 538, and $1 \mathrm{~J}$. KenT, CommenTaries on American Law 297 n.d (4th ed. New York 1840) (1st ed. New York 1826). Yet Marshall seems to have meant only that there was no statutory basis for jurisdiction, because he followed the quoted language with the statement "that the judiciary act does not authorize such suits." 19 U.S. (6 Wheat.) at 412. See HART \& WechsLer, supra note 41, at 1340. On the immunity question, conflicting inferences can be drawn from the statements elsewhere in Cohens that "a sovereign independent state is not suable, except by its own consent," $i d$. at 380 , and that federal question cases are cognizable "whoever may be the parties," $i d$. at 383. Federal immunity had earlier been suggested by two Justices in Chisholm v. Georgia, 2 U.S. (2 Dall.) 419, 469 (Cushing, J.); id. at 478 (Jay, C.J.). See Currie, supra note 1, at 83637.

284 19 U.S. (6 Wheat.) at 412. Marshall treated the case as one between the state and its own citizens, e.g., id. at 378, and counsel for the state declared that the Cohens were Virginia citizens, $i d$. at 303 .

${ }^{285}$ Id. at 406-12.

286 Id. at 408-09. Rejecting the argument that the amendment's reference to cases "prosecuted" as well as "commenced" included proceedings to review suits brought by states, Marshall construed it to embrace original complaints against states already pending when the amendment took effect, id. at 408 , as effectively held in Hollingsworth v. Virginia, 3 U.S. (3 Dall.) 378, 381 (1798), which he did not cite. See Currie, supra note 1, at 840. 
It was further contended that, if the Supreme Court could exercise jurisdiction at all, that jurisdiction must be original rather than appellate, for article III provides that the Court's jurisdiction shall be original in "all Cases affecting Ambassadors . . . and those in which a State shall be Party."287 Marshall had two answers for this argument as well, though one would have sufficed. The first required the embarrassment of retracting much of the reasoning he had used in Marbury v. Madison; as noted in connection with that case, ${ }^{288}$ he demonstrated in Cohens that the Framers could hardly have meant to prohibit Congress from giving appellate jurisdiction where the Constitution provided for original, and he left the Marbury holding essentially bereft of support. ${ }^{289}$ His second basis for rejecting the original jurisdiction argument was that the case was not within the original jurisdiction at all. Jurisdiction was original not whenever a state was a party, but only in "those cases in which jurisdiction is given, because a state is a party"- that is, when the opposing party was another state, a foreign state, or one of its citizens. ${ }^{280}$

This is not the most natural reading of the original jurisdiction clause, but it is not implausible. Marshall buttressed it with a rather persuasive argument based upon the practicalities of litigation. Federal questions often arise, as in Cohens itself, only after commencement of suits over which the Supreme Court had no jurisdiction at the outset. To deny appellate jurisdiction in such a case would be to deny the Court's jurisdiction altogether; it "would be to construe a clause, dividing the power of the supreme court, in such a manner, as in a considerable degree to defeat the power itself."201

287 U.S. ConsT. art. III, § 2, para. 2.

2ss See supra notes 51-58 and accompanying text.

260 19 U.S. (6 Wheat.) at 394-402. If Congress could not give the Court appellate jurisdiction of cases termed original by article III, he argued, the Court could not prevent a state court from exercising jurisdiction of suits against ambassadors, which were within its exclusive original jurisdiction; and "a clause inserted for the purpose of excluding the jurisdiction of all other courts than this, in a particular case, would have the effect of excluding the jurisdiction of this court, in that very case . . . ." Id. at 397.

Marshall's observations on the weight to be given dicta are instructive: "[G]eneral expressions" that "go beyond the case ... may be respected, but ought not to control the judgment in a subsequent suit" because, although "[t]he question actually before the court is investigated with care," the bearing on other cases of "[o]ther principles which may serve to illustrate it . . . is seldom completely investigated." Id. at 399-400.

${ }^{200}$ Id. at 393-94. The Court's later decision to entertain original jurisdiction in a controversy between the United States and a state, United States v. Texas, 143 U.S. 621, 643-45 (1892), is inconsistent with this reasoning.

${ }^{232} 19$ U.S. (6 Wheat.) at 394. In part this argument seems to rest upon Justice Story's 
Implicit in this line of argument was yet another important interpretation of article III, which Marshall expressly affirmed elsewhere in the opinion in response to a vague suggestion of counsel: because a case "consists of the right of the one party, as well as of the other," a case "arise[s] under the constitution or a law of the United States, whenever its correct decision depends on the construction of either."282 Because the point had not been challenged directly, perhaps Marshall may be forgiven for stating only the bald conclusion. That the point was not obvious is illustrated by the flatly contrary rule the Court has long followed in interpreting the same language in the statute providing for district court jurisdiction. ${ }^{293}$ The purposes of article III to unify and enforce federal law, emphasized both in Martin ${ }^{294}$ and elsewhere in Cohens, ${ }^{205}$ certainly support Marshall's result, ${ }^{296}$ but one wishes the Framers had adopted a more descriptive reference. ${ }^{287}$

Cohens showed that the new trend toward long opinions was not confined to Story. It also displayed many of the same qualities Marshall had exhibited in Marbury, his most extensive previous jurisdictional opinion: inattention to precedent, heavy emphasis on the intolerable consequences of a contrary decision, and insistence on reaching out for issues not necessarily presented. The strength of Cohens, like that of Marbury, lies in convincing the reader that the Framers were too wise and too patriotic to have created an imperfect Constitution. ${ }^{298}$

questionable position that removal before state court decision would be an exercise of appellate jurisdiction, see supra notes 238-40 and accompanying text, but it has force at least whenever federal questions arise for the first time in a state appellate court.

23219 U.S. (6 Wheat.) at 379.

29s E.g., Louisville \& N.R.R. v. Mottley, 211 U.S. 149, 152 (1908) ("[A] suit arises under the Constitution and laws of the United States only when the plaintiff's statement of his own cause of action shows that it is based upon those laws or that Constitution.").

294 See supra notes 235-36 and accompanying text.

203 See 19 U.S. (6 Wheat.) at 391-92.

29 See 3 J. STORY, supra note 109, at 509-10 (praising this aspect of Cohens: "Indeed, the main object of this clause would be defeated by any narrower construction; since the power was conferred for the purpose, in an especial manner, of producing a uniformity of construction of the constitution, laws, and treaties of the United States.").

2n The language recommended by a committee proposing amendments to the Articles of Confederation for appellate jurisdiction of cases "wherein questions shall arise on the meaning and construction of" federal law, 31 Journals of tHe Continental Congress 497 (1786), would clearly have embraced defendants' rights; it would, however, have exacerbated an additional problem discussed infra in notes 303-15 and accompanying text.

28 Cf. Monaghan, Our Perfect Constitution, 56 N.Y.U.L. Rev. 351 (1981). 


\section{Osborn v. Bank of the United States}

In defiance of square Supreme Court precedent, ${ }^{299}$ Ohio assessed a whopping $\$ 50,000$ tax against the Bank of the United States and collected it by force. The circuit court, having first enjoined collection of the tax, ordered the seized money returned. The Supreme Court, per Marshall, affirmed in 1824. ${ }^{300}$

The interesting questions once more were jurisdictional. ${ }^{301}$ Congress, Marshall rather debatably concluded, had attempted to give the federal circuit courts jurisdiction over all suits by or against the Bank. ${ }^{302}$ The next issue was whether Congress had power to do so.

In Osborn itself this question seemed relatively easy, for the Bank claimed that its federal charter gave it immunity from state taxation; the basic issue in the case was one of federal law. ${ }^{\text {sos }}$ In the companion Planters' Bank case, ${ }^{\text {,ot }}$ however, the bank sued on

200 McCulloch v. Maryland, 17 U.S. (4 Wheat.) 316 (1819).

20022 U.S. (9 Wheat.) 738 (1824).

${ }^{301}$ On the merits Marshall relied heavily on McCulloch, but typically he felt it necessary to retrace much of its reasoning, concluding with the unambiguous statement that Ohio's tax offended an implicit immunity found not in the Constitution itself but in the statute establishing the Bank. Id. at 865-68. Indeed on the merits Osborn was a stronger case for immunity than was $\mathrm{McC}$ Culloch, for the Ohio tax looked prohibitive; Marshall said it was "much more objectionable than that of the state of Maryland." Id. at 868.

sos The statute establishing the Bank made it "able and capable . . . to sue and be sued . . . in all state courts having competent jurisdiction, and in any circuit court in the United States." Bank of the United States Act, ch. 44, § 7, 3 Stat. 266, 269 (1816) (expired 1836). A few years earlier the Court had concluded that a similar provision conferred only capacity, not federal jurisdiction. Bank of the United States v. Deveaux, 9 U.S. (5 Cranch) 61, 85-86 (1809). In distinguishing this precedent, 22 U.S. (9 Wheat.) at 817-18, Marshall noted that the earlier statute had not specifically mentioned federal courts. He did not add, as he might have, that in view of the absence of a statute providing general federal question jurisdiction and the narrow construction of the diversity clause rendered in Deveaux, see supra notes 187-214 and accompanying text, it was difficult to see what the federal suability clause would have accomplished if read solely as a grant of capacity. Citing Deveaux, Johnson dissented on the statutory issue. 22 U.S. (9 Wheat.) at 876-84.

${ }^{303}$ As an original matter the Court might have held the case did not arise under federal law because the charter was entered only as a reply to a defense based on the state's tax law; Marshall's suggestion in Cohens that a suit to recover an unconstitutional tax arose upon an "assumpsit," see supra note 278, may look in that direction. Compare Gully v. First National Bank, 299 U.S. 109 (1936), effectively so holding in interpreting a jurisdictional statute essentially identical to the Constitution. As a constitutional matter, however, Marshall had gone some distance toward rejecting this interpretation with his statement elsewhere in Cohens that a case "consists of the right of one party, as well as of the other." 19 U.S. (6 Wheat.) at 379. A distinction between the original and appellate jurisdictions in this regard would have been respectable despite the fact that both depended upon the same words, but Marshall was at pains in Osborn to affirm that the original jurisdiction was as broad as the appellate. 22 U.S. (9 Wheat.) at 821.

sor Bank of the United States v. Planters' Bank, 22 U.S. (9 Wheat.) 904 (1824). 
a note it had acquired by assignment, and no one suggested that the law governing the validity or interpretation of the note was federal. Marshall's Osborn opinion was broad enough to embrace both cases. Because there was "scarcely any case, every part of which depends on the constitution, laws or treaties of the United States," 305 the mere fact that "the case involves questions depending on general principles" could not exclude it from the jurisdiction; ${ }^{308}$ it was enough that the Bank's ability to contract, which was based on federal law, "forms an original ingredient in every cause."307

Dissenting, Justice Johnson protested that the Bank's existence and its contractual capacity had not been questioned and were not likely to be questioned at this late date; he contended that the case could not be said to arise under federal law until the federal queston was actually raised. ${ }^{308}$ Johnson seems to have misinterpreted Marshall's opinion, ${ }^{309}$ for Marshall relied not on the potential controversy over the Bank's capacity but on the fact that that capacity was an essential part of the Bank's claim. In holding that no disagreement over the meaning of federal law was needed, Marshall was plainly right; because a central purpose of the arising-under provision is to vindicate federal rights, a defendant cannot defeat jurisdiction by conceding liability. ${ }^{310}$

The real difficulty with Marshall's opinion was not that the Bank's capacity was uncontested but that it was so remote from the central issues actually involved in the litigation. As Johnson demonstrated, the potential jurisdiction embraced by the Court's thesis was enormous: any action on paper subject to a federal stamp tax or any action respecting land once acquired from the United States could be brought within the jurisdiction. ${ }^{311}$ When Congress came to grant general arising-under jurisdiction, ${ }^{312}$ the

sos 22 U.S. (9 Wheat.) at 820.

${ }^{308} \mathrm{Id}$. at 821.

sot $I d$. at 824 .

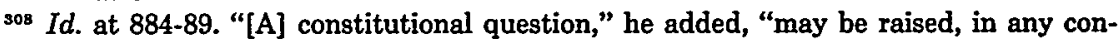
ceivable suit that may be instituted; but that would be a very insufficient ground for assuming universal jurisdiction ....." Id. at 886-87.

${ }^{308}$ As did Justice Frankfurter. See Textile Workers Union v. Lincoln Mills, 353 U.S. $448,471,481$ (1957) (dissenting opinion).

s10 This example helps to explain why, as Professor Mishkin has pointed out, "the term 'federal question" " as applied to trial court jurisdiction is a "misnomer" that might better be replaced "by some such term as 'federal claim." Mishkin, The Federal "Question" in the District Courts, 53 Colum. L. Rev. 157, 170-71 (1953) (emphasis in original).

32122 U.S. (9 Wheat.) at 874-76.

s12 Act of March 3,1875 , ch. 137, § 1, 18 Stat. 470, 470 (current version at 28 U.S.C. $\S$ 1331 (1976 \& Supp. IV 1980)). 
Court was to hold that it could not have intended to include cases in which the federal element was so remote. ${ }^{313}$ Moreover, Marshall's argument seems incomplete; rejection of the extreme position that all questions in the case must be federal did not compel the conclusion that a single federal ingredient would suffice. Yet the purpose of the arising-under clause seems to support Marshall's conclusion. Absent federal jurisdiction, a state might undermine the Bank's authority indirectly by improperly finding against it on some issue of state law; ${ }^{314}$ and, as Marshall noted, Supreme Court review would afford "the insecure remedy of an appeal, upon an insulated point, after it has received that shape which may be given to it by another tribunal, into which [a litigant] is forced against his will.",31s

The second great jurisdictional controversy in Osborn was one of sovereign immunity. The eleventh amendment forbids suits against one state by citizens of another; it was argued that the attempt to enjoin or to obtain restitution from a state officer in the course of his duties was "substantially, though not in form," a suit against the state. ${ }^{316}$ Stressing that such a conclusion would impede the enforcement of federal law, Marshall contrasted the amendment's reference to suits "against a State" with article III's provision for suits "affecting" ambassadors, analogized to the understanding that an executor's citizenship rather than that of the

s1s E.g., Shulthis v. McDougal, 225 U.S. 561,570 (1912) ("[A] controversy in respect of lands has never been regarded as presenting a Federal question merely because one of the parties to it has derived his title under an Act of Congress."). Cf. T.B. Harms Co. v. Eliscu, 339 F.2d 823 (2d Cir. 1964) (dispute over assignment of copyright).

s14 See Mishkin, supra note 310, at 162:

The potential judicial power of the United States over federal question cases must necessarily be extremely broad. The situations in which a sympathetic forum may be required for the vindication of national rights cannot always be foreseen, and there must be power under the Constitution to provide for those eventualities.

Johnson conceded in dissent that "a state of things has grown up, in some of the States, which renders all protection necessary, that the general government can give to this bank. The policy of the decision is obvious, that is, if the Bank is to be sustained . . . " 22 U.S. (9 Wheat.) at 871-72.

${ }^{315} 22$ U.S. (9 Wheat.) at 822-23. Compare England v. Louisiana State Bd. of Medical Examiners, 375 U.S. 411, 416 (1964), reaffirming, as Madison had insisted in the Convention, see supra note 246, that Supreme Court review was "an inadequate substitute" for an initial federal determination, especially with respect to "issues of fact": "Limiting the litigant to review here would deny him the benefit of a federal trial court's role in constructing a record and making fact findings. How the facts are found will often dictate the decision of federal claims." See 1 C. WarRzN, supra note 23, at 629 ("Had the point been successfully maintained and the Bank excluded from the Federal Courts and obliged to trust its fate to local juries, its fortunes would have been highly insecure.").

sie 22 U.S. (9 Wheat.) at 846. See id. at 803-04 (Mr. Wright). 
beneficiaries was determinative for diversity purposes, and concluded that the amendment was "limited to those suits in which a state is a party on the record." "317

The trouble with this reasoning is that it reduces the amendment to an empty shell; it is not easy to imagine any policy that might have prompted the country to go to the length of amending the Constitution to forbid suing states by name while allowing suits with identical effects against their officers. Thus while Marshall invoked his pet arguments of intolerable consequences, ${ }^{318} \mathrm{Os}$ born seems to have been a case in which that argument cut more strongly against him. Indeed, Marshall himself would soon retract the more extreme implications of Osborn in disallowing a suit against state officers to obtain possession of slaves seized when allegedly imported in violation of federal law; ${ }^{319}$ the Court has been

317 Id. at 847-58. It is noteworthy that Marshall did not contend that the amendment was inapplicable on the ground that the suit had been brought not by citizens of other states but by a federal corporation. An adequate explanation would be that he had already held in Deveaux that a suit by a corporation was to be treated as a suit by its members. Bank of the United States v. Deveaux, 9 U.S. (5 Cranch) 61, $91-92$ (1809); see supra notes 192-95, 205, and accompanying text. There was some acknowledged tension between this position and the flat statement in Osborn that "in all cases where jurisdiction depends on the party, it is the party named in the record." 22 U.S. ( 9 Wheat.) at 857. Perhaps the results can be reconciled on the ground that the eleventh amendment speaks explicitly of "State[s]," while neither it nor article III mentions corporations.

s1s 22 U.S. (9 Wheat.) at $847-48$ ("it may not be time misapplied, if we pause for a moment, and reflect on the relative situation of the Union with its members, should the objection prevail"). See also 1 J. KeNT, supra note 283, at 350-51 (discussing Osborn: "[T]he objection, if it were valid, would go, in its consequences, completely to destroy the powers of the Union.").

s10 Governor of Georgia v. Madrazo, 26 U.S. (1 Pet.) 110 (1828). Osborn was distinguished on the unpromising grounds that in Madrazo the Governor was sued "not by his name, but by his title," and that he had "done nothing in violation of any law of the United States." Id. at 123-24. Johnson, who had entertained the case below, dissented, but not from this reasoning; he argued that by initiating a proceeding to condemn the slaves the state had effectively been plaintiff rather than defendant in the case. Id. at 124-35.

Madrazo's claim had been filed in admiralty, because it related to cargo sold after capture at sea, and it was plausibly argued that the eleventh amendment did not apply because the case was not one "in law or equity." Id. at 116-17; cf. Parsons v. Bedford, 28 U.S. (3 Pet.) 433, 446-47 (1830) (neither admiralty nor equity cases were "Suits at common Law" within the seventh amendment jury provision) discussed infra in notes 358-62 and accompanying text. Marshall avoided the issue: "[I]f the 11th amendment . . . does not extend to proceedings in admiralty, it was a case for the original jurisdiction of the supreme court" because it was a suit between a state and a foreign national. 26 U.S. (1 Pet.) at 124. Yet under section 13 of the Judiciary Act of 1789 the Supreme Court's jurisdiction was "original but not exclusive" in such cases, ch. $20, \S 13,1$ Stat. 73,80 (current version at 28 U.S.C. $\S$ 1251 (1976)); Cohens seemed to support the conclusion that the Constitution itself did not make the original jurisdiction exclusive, see supra notes $260-98$ and accompanying text, and the district court had jurisdiction in admiralty under section 9, 1 Stat. at 76-77 (current version at 28 U.S.C. $\S 1333$ (1976)). 
searching without much success for a rationale to distinguish these two cases ever since. ${ }^{320}$ Marshall might have helped his cause by arguing that virtually automatic permission to file petitions of right rendered purely symbolic the English immunity tradition on which the amendment was based, ${ }^{321}$ but in typical fashion he disdained reliance on British precedents, ${ }^{322}$ just as he ignored relevant previous pronouncements of his own. ${ }^{323}$

Educated by Marshall's advice, Madrazo next filed a libel against Georgia herself directly in the Supreme Court. Once more Marshall avoided the question of the effect of the eleventh amendment on admiralty cases, concluding, despite the assumption of all concerned, that the case was not maritime: "It is a mere personal suit against a state, to recover proceeds in its possession . . . ." Ex parte Madrazzo [sic], 32 U.S. (7 Pet.) 627, 632 (1833).

Much later the Court was to hold an unconsenting state could not be sued in admiralty. Ex parte New York, 256 U.S. 490, 498 (1911). Cf. Hans v. Louisiana, 134 U.S. 1 (1890), discussed supra in note 283.

s20 See, e.g., Edelman v. Jordan, 415 U.S. 651 (1974); Pennoyer v. McConnaughy, 140 U.S. 1, 9-10 (1891). See D. Currie, Frderral Courts-Cases and Materials 557-67 (3d ed. 1982); C. Jacobs, The Eleventr Amendment and Sovereign ImmuntTy 106-49 (1972). Marshall suggested a basis of distinction when he argued in Osborn, 22 U.S. (9 Wheat.) at 858, that the "true question" was "not one of jurisdiction, but whether [the defendants] are to be considered as having a real interest, or as being only nominal parties." 3 J. SToRy, supra note 109 , at $539-40$, pursued this theme by invoking common law principles making an agent or servant generally liable for torts committed but not for contracts made on behalf of his employer.

321 See Chisholm v. Georgia, 2 U.S. (2 Dall.) 419, 460 (Wilson, J.), discussed in Currie, supra note 1, at 838-39. See also United States v. Lee, 106 U.S. 196, 208 (1883) (explaining the paucity of British precedents in which officers had been sued: "There has been, therefore, no necessity for suing the officers or servants of the King . . ., when the issue could be made with the King himself as defendant.").

322 If this question were to be determined on the authority of English decisions, it is believed, that no case can be adduced, where any person has been considered a party, who is not so made in the record. But the court will not review those decisions, because it is thought, a question growing out of the constitution of the United States, requires rather an attentive consideration of the words of that instrument, than of the decisions of analogous questions by the courts of any other country.

22 U.S. (9 Wheat.) at 851 . Indeed it is arguable that, however symbolic the English doctrine may have been, the country must have meant to do something beyond symbolism when it took the trouble to amend the Constitution.

s1s Marshall cited neither his statement in Marbury, 5 U.S. (1 Cranch) at 170 ("If one of the heads of departments commits any illegal act, under color of his office, by which an individual sustains an injury, it cannot be pretended, that his office alone exempts him from being sued in the ordinary mode of proceeding . . . ."), nor his decision in United States v. Peters, 9 U.S. (5 Cranch) 115, 139-41 (1890) (enforcing over eleventh amendment objections a decree against representatives of a deceased state treasurer respecting "the proceeds of a vessel condemned in the court of admiralty": "[T]he suit was not instituted against the state, or its treasurer, but against the executrices of David Rittenhouse"; the state "had neither possession of, nor right to, the property"; and "a mere suggestion of title in a state, to property in possession of an individual," could not destroy jurisdiction.).

Later Justices, rightly or wrongly, were to rely on Peters as the substantial equivalent of Osborn, see, e.g., United States v. Lee, 106 U.S. 196, 209-14 (1883), though in Lee the treasurer had asserted no personal rights. Both Peters and an English case alleged to have 
The companion Planters' Bank case ${ }^{324}$ raised a somewhat different eleventh amendment problem, for in that case the defendant was not a state officer but a bank in which the state itself was a shareholder. Marshall was brief in upholding jurisdiction. The suit was "no more a suit against the state of Georgia, than against any other individual corporator"; it was a suit "against a corporation." ${ }^{325}$ Moreover,

when a government becomes a partner in any trading company, it divests itself, so far as concerns the transactions of that company, of its sovereign character .... The State of Georgia, by giving to the bank the capacity to sue and be sued, voluntarily strips itself of its sovereign character, . . . and waives all the privileges of that character . . . ${ }^{328}$

No fewer than three distinct bases for the decision are imbedded in this reasoning: the state was not a party, the amendment does not forbid suits against a state in its proprietary capacity, and the state had waived its immunity by consenting to suits against the bank. Each was stated as a bare conclusion, and each was subject to significant objections.

Johnson in dissent pointed out two of the problems. First, the holding that the state was not a party was difficult to reconcile with Bank of the United States v. Deveaux, ${ }^{327}$ in which a diversity suit by a corporation had been considered a suit by its members. ${ }^{328}$ Second, Johnson argued, every suit against a state was in its "sovereign capacity"; "in what other capacity can a state appear, or even exist?"'828 We might be inclined to put this point somewhat differently by saying that the eleventh amendment bars all suits in law or equity against a state by citizens of another, with no exception for proprietary activities. ${ }^{\text {so }}$

involved the recovery of illegally collected taxes had been invoked by counsel. 22 U.S. (9 Wheat.) at 797 (Mr. Clay).

s34 Bank of the United States v. Planters' Bank, 22 U.S. (9 Wheat.) 904 (1824).

s2s Id. at 906-07.

s28 Id. at 907-08.

3279 U.S. (5 Cranch) 61 (1809).

32322 U.S. (9 Wheat.) at 911-12; see supra notes 192-95, 205, and accompanying text. See Louisville R.R. v. Letson, 43 U.S. (2 How.) 497, 554 (1844) (arguing that Planters' had essentially overruled Deveaux). As in Osborn, see supra notes 316-23 and accompanying text, Marshall made no attempt in Planters' to argue that the eleventh amendment was inapplicable because the suit had been brought by a'corporation.

3992 U.S. (9 Wheat.) at 912.

sso Later decisions seem basically to have rejected Marshall's governmental/proprietary distinction. E.g., Ex parte New York, 256 U.S. 490, 500-03 (1921) (upholding without discussion a state's immunity to suit arising out of a collision with its tugboat); cf. Berizzi Bros. 
Johnson did not advert to the waiver question. Later Justices have questioned whether waivability is consistent with the absolute language of the amendment; ${ }^{331}$ the answer, if there is one, must be based upon the perception that the immunity, like a venue statute, exists for the protection of the defendant. ${ }^{332}$ Apart from this, later cases have construed waivers of state immunity strictly, ${ }^{\text {sss }}$ and Marshall did not say the statute expressly made the bank suable in federal court. Johnson's objections were at the least sufficient to give pause as to the soundness of the Court's conclusions, yet Marshall did not stop to answer them. ${ }^{334}$

Thus Osborn and its companion case show Marshall at his most dogmatic and impervious to argument. His broad construction of the arising-under clause could have been made more persuasive by borrowing a page out of Story's use of the constitutional purpose in Martin v. Hunter's Lessee; ${ }^{\text {sss }}$ it was based instead on the demolition of a straw man. Marshall's conclusions with regard to sovereign immunity were enough to destroy the eleventh amendment. His conclusory opinion in Planters' Bank, with its conspicuous failure to respond at all to a dissent responsibly invoking precedent, is the statement of a lawgiver confident of his power and sensitive to no compelling obligation to persuade.

Co. v. Steamship Pesaro, 271 U.S. 562 (1926) (merchant ship owned by foreign sovereign). Yet considerations of the proprietary nature of the state's activity have reappeared in recent years in connection with the question whether the state has consented to be sued. Compare Parden v. Terminal Ry., 377 U.S. 184 (1964) (allowing suit against state-owned railroad) with Employees v. Department of Public Health \& Welfare, 411 U.S. 279, 284 (1973) (distinguishing Parden on the ground that "[s]tate mental hospitals, state cancer hospitals, and training schools for delinquent girls which are not operated for profit, are not proprietary."). The Foreign Sovereign Immunities Act, 28 U.S.C. $\$ \S 1604,1605$ (a)(2) (1976), whose constitutionality remains to be tested, adopts a similar distinction.

${ }^{232}$ See, e.g., Employees v. Department of Public Health \& Welfare, 411 U.S. 279, 321 (1973) (Brennan, J., dissenting).

sas See Clark v. Barnard, 108 U.S. 436, 447 (1883) ("The immunity from suit belonging to a State . . . is a personal privilege which it may waive at pleasure.").

${ }^{33 s}$ E.g., Kennecott Copper Co. v. State Tax Comm'n, 327 U.S. 573, 577 (1946).

2s Planters' was extended to a case where the state was sole owner of stock in the defendant bank in Bank of Kentucky v. Wister, 27 U.S. (2 Pet.) 318 (1829). Johnson, who had dissented in Planters', wrote the brief opinion, quoting Marshall's language about the state "divest[ing] itself" of sovereignty when it engages in trade. Id. at 323 . He added that the case was easier than Planters', for in Wister the state was merely a shareholder, not a "corporator"; only the president and directors constituted the body corporate. Id. Thus phile Johnson appeared in Wister to bow to adverse precedent, he was in one sense consistent with his own prior position.

223 See supra notes $235-36$ and accompanying text. 


\section{Other Cases}

\section{A. Houston v. Moore}

Among the more interesting jurisdictional cases not yet noted is the Court's 1820 decision upholding Pennsylvania's right to try a militiaman for failure to report for duty when his unit was called into federal service. ${ }^{388}$ Here we encounter for the first time Justice Bushrod Washington, who had been on the Court for over twenty years; we shall meet him only very occasionally later on. After deciding that a federal statute punished the same offense and thus implicitly occupied the field, ${ }^{387}$ Washington concluded that the state could assert jurisdiction to enforce the federal law: when Congress meant federal jurisdiction to be exclusive, it said so expressly..$^{38 s}$

Two constitutional principles, which Washington found confirmed by congressional understanding and by The Federalist, un-

ss6 18 U.S. (5 Wheat.) 1 (1820).

ss7 "If . . . one [government] imposes a certain punishment, for a certain offence, the presumption is, that this was deemed sufficient, and, in all circumstances, the only proper one." Id. at 23. Cf. Pennsylvania v. Nelson, 350 U.S. 497 (1956) (federal ban on activities subverting federal government precludes similar state law). Yet examples of state and federal punishment for the same act are not uncommon, see, e.g., Moore v. Illinois, 55 U.S. (14 How.) 13 (1852 Term) (concealment of fugitive slave), and examples cited id. at 19-20; Congress may have meant only to make certain that the offending act was punished, and indeed parallel state action might have been viewed as reinforcing federal policy. Justice Johnson, citing examples, expressly disagreed with Washington's conclusion on this point. 18 U.S. (5 Wheat.) at 33-36 (Johnson, J., concurring). Compare Marshall's statement in Cohens v. Virginia, 19 U.S. (5 Wheat.) at 443 ("To interfere with the penal laws of a State, where they ... have for their sole object the internal government of the country, is a very serious measure, which Congress cannot be supposed to adopt lightly . . . ."). Shortly after Houston, Congress enacted an ambiguous law providing that nothing in the new federal criminal code should be construed "to deprive the courts of the individual states, of jurisdiction, under the laws of the several states, over offences made punishable by this act." Act of March 3, 1825, ch. 65, § 26, 4 Stat. 115, 122-23 (current version at 18 U.S.C. $\S 3231$ (1976)). For varying judicial interpretations of this provision, see Grant, The Scope and Nature of Concurrent Power, 34 CoLuM. L. REv. 995, 1013 (1934). Compare the question of preclusion of state law by federal action permitting, rather than prohibiting, an activity. E.g., Gibbons v. Ogden, 22 U.S. (9 Wheat.) 1 (1824).

Washington's conclusion that the federal statute precluded a parallel state enactment followed two unnecessary but interesting conclusions respecting the arguable exclusivity of article I's grant of authority over the militia. It had correctly been conceded, he declared, that Congress's power was exclusive after the militia had been federalized, but not before. 18 U.S. (5 Wheat.) at 16-17. Story's dissent reinforced the former point: "[T] o suppose each state could have an authority to govern its own militia in such cases, . . . seems utterly inconsistent with that unity of command and action, on which the success of all military operations must essentially depend." Id. at 53. Cf. Wayman v. Southard, 23 U.S. (10 Wheat.) 1 (1825); Gibbons v. Ogden, 22 U.S. (9 Wheat.) 1 (1824); Sturges v. Crowninshield, 17 U.S. (4 Wheat.) 122 (1819).

sse 18 U.S. (5 Wheat.) at 25-32. 
derlay this conclusion: that the constitutional power over federal question cases was not itself exclusive and that Congress had power to exclude concurrent state court jurisdiction. ${ }^{\text {sse }}$ Dissenting on the ground that the statute made federal jurisdiction exclusive, ${ }^{340}$ Story appeared also to conclude, as he had unnecessarily suggested in Martin v. Hunter's Lessee, ${ }^{341}$ that the constitutional grant itself was exclusive in criminal cases. ${ }^{342}$ The compromise by which the Framers made the creation of inferior federal courts discretionary $^{343}$ seems to imply, Story to the contrary, that the trial of all article III cases might be left to state courts. ${ }^{\text {s4t }}$ However, in

135 See id. at 25-26 (citing The Frderalist No. 82 (A. Hamilton)), Compare Judiciary Act of 1789 , ch. $20, \S 9,1$ Stat. 73,76 (repealed 1911) (current version at 18 U.S.C. $\$ 3231$ (1976)) (criminal jurisdiction of the federal trial courts "exclusive") with id. $\S 11,1$ Stat. at 78 (repealed 1911) (current version at 28 U.S.C. $\& 1332$ (1976)) (diversity jurisdiction "concurrent").

3418 U.S. (5 Wheat.) at 71-72.

s1 14 U.S. (1 Wheat.) 304 (1816).

212 It cannot be pretended, that the states have retained any power to enforce fines and penalties created by the laws of the United States, in virtue of their general sovereignty, for that sovereignty did not originally attach on such subjects. They sprang from the Union, and had no previous existence. . . .

... It has been expressly held by this court, that no part of the criminal jurisdiction of the United States can, consistently with the constitution, be delegated by congress to state tribunals.

18 U.S. (5 Wheat.) at 68-69, citing Martin v. Hunter's Lessee, 14 U.S. (1 Wheat.) 304, 336-37 (1816) (dictum), where the same nondelegation statement had followed the declaration that "the judicial power of the United States is unavoidably, in some cases, exclusive of all state authority, and in all others may be made so at the election of congress." Yet Story in Houston also distinguished eramples of state court jurisdiction to enforce federal penal laws on the ground that in those instances Congress had expressly provided that it did not mean to deprive state courts of jurisdiction. 18 U.S. (5 Wheat.) at 74. In his treatise he conceded that although Congress could not vest jurisdiction over any cases in state courts, it could "permit the state courts to exercise a concurrent jurisdiction in many cases," and he followed that statement with a reference to criminal examples. 3 J. STORY, supra note 109, at 622-24. Story reminded the reader, however, that Martin had also "held" the constitutional grant of admiralty jurisdiction partly exclusive because there was "a direct repugnancy or incompatibility in the exercise of it by the states." 18 U.S. (5 Wheat.) at 49, citing Martin, 14 U.S. (1 Wheat.) at 337 ("it can only be in those cases where, previous to the constitution, state tribunals possessed jurisdiction independent of national authority, that they can now constitutionally exercise a concurrent jurisdiction"). See also 3 J. STORY, supra note 109, at 534 n.3 (explaining that the Constitution conferred admiralty jurisdiction "exactly according to the nature and extent and modifications, in which it existed in the jurisprudence of the common law. Where the jurisdiction was exclusive, it remained so."). To today's reader the alleged "repugnancy" between state and federal admiralty powers seems hard to find, and the alleged exclusivity of the constitutional admiralty grant is not easy to reconcile with the broad statements of The Federalist relied on by Washington in Houston, 18 U.S. (5 Wheat.) at 25-26 (1820). See supra note 339.

s13 See supra note 246.

34 This consideration appears to refute the possibility that the tenure provisions of U.S. CoNsT. art. III, $₹ 1$, which forbid the creation of federal judges lacking independence, also forbid state court jurisdiction over cases within federal authority. See infra note 350 . 
light of Story's opinion, the Martin dictum, and occasional state court decisions embracing Story's position, ${ }^{345}$ Washington would have been better advised to address the issue in greater detail. For the very passage of The Federalist on which he so heavily relied was based on the tradition that "[ $t]$ he judiciary power of every government looks beyond its own local or municipal laws, and in civil cases, lays hold of all subjects of litigation between parties within its jurisdiction . . . ."348 The implicit traditional corollary that " $[t]$ he courts of no country execute the penal laws of another," "\$47 which Story recited in his dissent, ${ }^{348}$ cried aloud for an answer. This would not be the last time the notion that states were forbidden to exercise certain heads of article III jurisdiction would crop up, ${ }^{348}$ but in general Washington's views have prevailed: the states may hear article III cases unless Congress otherwise provides. $^{350}$

See also Warren, Federal Criminal Laws and the State Courts, 38 Harv. L. Rev. 545 (1925) (arguing exhaustively that the criminal jurisdiction need not be exclusive).

sus See, e.g., Jackson v. Row, 2 Va. Cas. 34, 35-38 (1815); Warren, supra note 344, at 577-80 (and cases discussed therein).

s6 The Federalist No. 82, supra note 56, at 493 (A. Hamilton) (emphasis added). Washington's paraphrase omitted the important word "civil."

${ }^{347}$ Wisconsin v. Pelican Ins. Co., 127 U.S. 265, 290 (1888) (quoting Marshall in The Antelope, 23 U.S. (10 Wheat.) 66, 123 (1825)); see supra note 270 (discussing Cohens).

s4s 18 U.S. (5 Wheat.) at 69.

se See, e.g., United States v. Bailey, 34 U.S. (9 Pet.) 238, 259 (1835) (McLean, J., dissenting), and the peculiar opinion of Justice Johnson in Ogden v. Saunders, 25 U.S. (12 Wheat.) 213, 271 (1827). Both 1 Tucker's Appendix to Blackstone, supra note 86, at 181-82, and W. Rawle, A VIEW of the Constitution of the United States of AMerica 202-08 (2d ed. Philadelphia 1829) (1st ed. Philadelphia 1825), took the position that in some cases the Constitution made federal jurisdiction exclusive.

sso See, e.g., Charles Dowd Box Co. v. Courtney, 368 U.S. 502 (1962) (federal jurisdiction to enforce collective bargaining contracts affecting commerce not exclusive). Compare Tennessee v. Davis, 100 U.S. 257 (1880) (denying constitutional status to Story's doctrine against enforcing foreign penal laws by upholding a statute authorizing removal to federal court of state prosecutions of federal officers), discussed in Warren, supra note 252, at 59294. The power to make federal jurisdiction exclusive, which was not directly involved in Houston, was confirmed without significant discussion in The Moses Taylor, 71 U.S. (4 Wall.) 411, 429-30 (1867), which by basing the exclusivity of federal jurisdiction over a maritime in rem proceeding on the statute avoided embracing Story's argument that the Constitution itself made jurisdiction exclusive. Without giving reasons, and despite the broad dictum in Houston, Rawle argued state courts could not be deprived of jurisdiction over diversity cases, or over "many other[s]." W. RAwLE, supra note 349, at 205 n.t.

Washington added in Houston, quite unnecessarily, that "congress cannot confer jurisdiction" on state courts. 18 U.S. (5 Wheat.) at 27. In agreeing with Washington on this point Story took a narrow view of the necessary and proper clause, U.S. CoNST. art. I, § 8, cl. 18: "The nation may organize its own tribunals for this purpose; and it has no necessity to resort to other tribunals to enforce its rights." 18 U.S. (5 Wheat.) at 67. Cf. McCulloch v. Maryland, 17 U.S. (4 Wheat.) 316 (1819). See also 1 J. KeNT, supra note 283, at 402 ("The doctrine seems to be admitted, that congress cannot compel a state court to entertain juris- 
Washington, however, cannot be said to have spoken for the Court in Houston; he noted that while all but two Justices agreed that the judgment should stand, "they do not concur in all respects in the reasons which influence my opinion."ss1 What is peculiar is that except for Johnson, who wrote a long concurrence, ${ }^{362}$ we do not know the grounds on which the other Justices voted. Nor can we be certain who the second dissenter was; Story revealed only that his opinion had "the concurrence of one of my brethren."3ss

\section{B. Judicial Provisions of the Bill of Rights}

One of the arguments against permitting state court jurisdiction in Houston was, as Washington put it, that the determination of the state court "would either oust the jurisdiction of the United States court-martial, or might subject the accused to be twice tried for the same offence", ${ }^{\text {sst }}$ Story, in applying the Court's holding to a hypothetical case of treason, expressly invoked the double jeopardy clause of the fifth amendment. . $^{\text {ss }}$ Washington did not address the double jeopardy question, ${ }^{356}$ and indeed Bill-of-Rights issues,

diction in any case."). The Court was to repudiate this position in part many years later. See Testa v. Katt, 330 U.S. 386, 394 (1947) (holding a state court required to entertain a treble-damage action under the Emergency Price Control Act).

ss 18 U.S. (5 Wheat.) at 32. Johnson was still more emphatic: "[T]here is no point whatever decided, except that the fine was constitutionally imposed .... The course of reasoning by which the judges have reached this conclusion are [sic] various . . . ." Id. at 47.

282 Id. at 32-47 (arguing that the defendant had not violated federal law and that the state could make the same act a crime even if he had).

233 Id. at 76. One suspects it may have been Marshall; the disintegration of the majority in Houston was paralleled during the Marshall years only in Ogden v. Saunders, 25 U.S. (12 Wheat.) 213 (1827), the one constitutional case in which the Chief Justice openly dissented. Johnson's biographer, citing a letter of the Chief Justice and one of his opinions on circuit, Meade v. Deputy Marshall, 16 F. Cas. 1291 (No. 9372) (C.C.D. Va. 1815), neither of which appears conclusive, says the other dissenter "was doubtless Marshall." D. MoRGaN, supra note 13 , at 244 n.48.

256 U.S. (5 Wheat.) at 31.

2ss Id. at 75.

256 Washington said the state judgment would be as binding as one in a civil case, presumably under the statute requiring "every court within the United States" to give "faith and credit" to state court judgments, Act of May 26, 1790, ch. 11, 1 Stat. 122, 122 (1790) (current provision at 28 U.S.C. $\$ 1738$ (1976)), or under the common law doctrine of res judicata. See 18 U.S. (5 Wheat.) at 31. Story argued that to allow a second trial would offend legislative intent, common law principles, and "the genius of our free government." Id. at 72. The lack of reliance in either opinion on the fifth amendment seems attributable to the fact that the sentence in question was a mere fine, while the amendment speaks only of "jeopardy of life or limb." See id. at 34 (Johnson, J., concurring).

A related problem was presented in United States v. Perez, 22 U.S. (9 Wheat.) 579, 580 (1824), a brief Story opinion allowing a criminal defendant to be retried after discharge of a hung jury, on the ground that the law allowed a judge to abort the trial in cases of "manifest 
even those respecting judicial procedure, rarely reached the Court during the Marshall period. The seventh amendment's civil jury guarantee was at stake, however, in cases defining the scope of the admiralty jurisdiction, because the Judiciary Act exempted admiralty cases from the jury requirement. ${ }^{.57}$ In an important dictum in Parsons $v$. Bedford, ${ }^{\text {s88 }}$ Story confirmed in 1830 the validity of this exception, declaring that the constitutional guarantee in suits at common law "may well be construed to embrace all suits, which are not of equity and admiralty jurisdiction, whatever may be the peculiar form which they may assume to settle legal rights." this conclusion he relied convincingly on the language of article III, which distinguishes between "Cases, in Law and Equity," and "Cases of Admiralty or maritime jurisdiction,"s60 and on the historical observation that juries had been used in new proceedings involving "legal rights" but usually not in admiralty or in equity. ${ }^{361}$ Thus at the same time that Story left equity and admiralty cases

necessity" or when "the ends of public justice would otherwise be defeated." Later Justices have tended to read this case as implying that a declaration of mistrial without "manifest necessity" would offend the fifth amendment, e.g., United States v. Dinitz, 424 U.S. 600, 606-07 (1976), but the interesting feature of the case is that the Constitution was not mentioned; evidently the Court thought the double jeopardy clause had nothing to do with the question. Story reveals why in his treatise: if the jury is discharged before verdict, the defendant "cannot judicially be said to have put in jeopardy." 3 J. SToRY, supra note 109, at 65960 (citing Perez). See Crist v. Bretz, 437 U.S. 28, 34 n.10 (1978), enforcing a contrary rule while acknowledging that Perez had been misunderstood: though in Perez "the Court was not purporting to decide a constitutional question, ... . to cast such a new light on Perez at this late date would be of academic interest only" in view of intervening decisions.

ss7 Judiciary Act of 1789 , ch. $20, \S \S 9,12,1$ Stat. 73, 77, 80 (current version at 28 U.S.C. $\S 1873$ (1976)). See infra note 375 and accompanying text (discussing The Thomas Jefferson).

35828 U.S. (3 Pet.) 433 (1830).

s59 Id. at 447 .

${ }^{300}$ U.S. CoNsT. art. III, \& 2, para. 1.

so1 This historical test requires the courts to engage in much esoteric research irrelevant to the underlying policies respecting the desirability of jury trials, see, e.g., Damsky v. Zavatt, 289 F.2d 46, 48 (2d Cir. 1961), and there has been a tendency to reevaluate the availability of equitable remedies in light of modern procedure, see, e.g., Ross v. Bernhard, 396 U.S. 531, 540 (1970); Beacon Theatres, Inc. v. Westover, 359 U.S. 500, 506-10 (1959). Yet some such irrelevant digging seems scarcely avoidable in light of Congress's debatable decision to phrase its proposed amendment in terms of distinctions that had developed for reasons not always related to the desirability of jury trial. For discussions of this problem, see, e.g., F. James \& G. Hazard, Crvil Procedure 347-91 (2d ed. 1970); Redish, Seventh Amendment Right to Jury Trial: $A$ Study in the Irrationality of Rational Decision Making, 70 Nw. U.L. REv. 486 (1975); Wolfram, The Constitutional History of the Seventh Amendment, 57 MrNN. L. REv. 639 (1973), especially id. at 710-22 and 731-47, urging a "dynamic" rather than a strictly historical test and noting that throughout their history "the jurisdictions of the law courts and the chancellor . . . were subject to an unstatic process of accretion and erosion." 
outside the jury provision, he read into the amendment a capacity for growth: it covered not only proceedings known to the common law when the amendment was adopted, but nonequity, nonmaritime proceedings later created by statute as well..$^{362}$

The seventh amendment had come up once before, in the 1819 case Bank of Columbia $v$. Okely, ${ }^{868}$ which, apart from undercurrents in the admiralty cases, may have been the first Bill-of-Rights case in the Supreme Court. A Maryland statute, incorporated by Congress in establishing the District of Columbia, authorized summary collection without trial of any notes expressly made negotiable at the bank; the Court upheld it over objections based on the seventh amendment and the jury and "law of the land" clauses of the Maryland constitution. ${ }^{384}$ The seventh amendment jury guar-

so2 See, e.g., Curtis v. Loether, 415 U.S. 189, 193 (1974) (statutory damage action for housing discrimination). In interesting contrast was the actual holding in Parsons, refusing to reverse a judgment for failure to transcribe the evidence taken before the jury, as Louisiana law prescribed, despite a federal statute conforming practice in the Louisiana federal court to state law. The second clause of the seventh amendment precluded reexamination of facts found by a jury "otherwise . . . than according to the rule of the common law." Because at common law an appellate court had no power to investigate the facts found by a jury, said the Court, the statute should be construed not to authorize broader appellate review, so as to avoid "the most serious doubts, whether it would not be unconstitutional." 28 U.S. (3 Pet.) at 448. Any error in failing to record the evidence was therefore harmless. Id. In short, the Court seems to have viewed the reference to "common law" methods of reviewing juries as confining it rather strictly to 1791 practice, while interpreting the identical term in the preceding clause to require juries in new actions analogous to those already recognized at common law. For later developments in this area, see, e.g., Baltimore \& Carolina Line v. Redman, 295 U.S. 654, 659 \& n.5 (1935) (upholding the validity of a judgment notwithstanding the verdict and invoking pre-1791 precedent in cases in which the issue of sufficient evidence had been reserved).

s6s 17 U.S. (4 Wheat.) 235 (1819).

sou The peculiar hybrid nature of the law made the basis of Johnson's brief opinion somewhat obscure. He began by observing plausibly enough that because Congress had adopted only "existing" Maryland laws, state constitutional objections could not be avoided by reference to Congress's power to legislate for the District. Id. at 242 . He went on to find it therefore "unnecessary to examine the question, whether the powers of Congress be despotic in this district, or whether there are any, and what, restrictions imposed upon it, by natural reason, the principles of the social compact, or constitutional provisions." Id. As we shall see in Fletcher v. Peck, 10 U.S. (6 Cranch) 87 (1810), Johnson was at this time a follower of Chase's views as to the invalidity of unjust statutes. See Currie, supra note 1, at 871-74. Johnson's conclusion that Maryland's law-of-the-land clause was "intended to secure the individual from the arbitrary exercise of the powers of government, unrestrained by the established principles of private rights and distributive justice," 17 U.S. (1 Wheat.) at 244, prefigured the later treatment of its federal due process cousin in such cases as Lochner v. New York, 198 U.S. 45 (1905). See also Livingston v. Moore, 32 U.S. (7 Pet.) 469, 551 (1833) (Johnson, J.).

Johnson seems to have been wrong in concluding that the reference to "existing" Maryland law made consideration of limits on Congress unnecessary. Even if Maryland were free to enact the law, Congress might have lacked power to adopt it. More surprisingly still, Johnson proceeded to consider on its merits the question whether the original Maryland law 
antee, wrote Justice Johnson for the Court, was waivable and had been waived. By preserving the "right" of trial by jury, the Constitution gave the party a "benefit" that might be "relinquished," and by signing the note the debtor had "voluntarily relinquished his claims to the ordinary administration of justice." ${ }^{\text {s8s }}$ On the general point of waivability the language certainly cuts in Johnson's favor, ${ }^{368}$ and though later decisions suggest caution in relying on the words alone without consideration of their antecedents or purposes, ${ }^{387}$ counsel apparently did not contend that the jury could never be waived. ${ }^{368}$ To classify a right as a personal privilege, however, is not necessarily to prove that it can be surrendered in advance of any dispute by signing a form contract. ${ }^{368}$ Indeed, Johnson recognized that the words of the Constitution might not afford an answer to all questions respecting waiver. He prudently reserved the question of whether the Court would uphold an act that

had offended the seventh amendment, 17 U.S. (4 Wheat) at 242-44; he seems to have thought, contrary to the Court's later conclusion in Barron v. Baltimore, 32 U.S. (7 Pet.) 243 (1833), that the Bill of Rights applied to the states, though he neglected to address this portentous issue. See D. Morgan, supra note 13, at 135. Thus Okely did not face the question, though it should have, whether the seventh amendment applied to the District of Columbia. Cf. supra notes 130-44, 165-78, 260-98, infra notes $415-35$, and accompanying text (discussing United States v. More, Hepburn v. Ellzey, Cohens v. Virginia, and American Insurance Co. v. Canter).

${ }^{365} 17$ U.S. (4 Wheat.) at 243-44.

sse Compare Gannett Co. v. DePasquale, 443 U.S. 368, 382-87 (1979); Adams v. United States ex rel. McGann, 317 U.S. 269, 275 (1942); and Patton v. United States, 281 U.S. 276, 307-13 (1930), allowing criminal defendants to waive the similarly phrased sixth amendment "right[s]" to a public trial, to the assistance of counsel, and to trial by jury, respectively.

sor See, e.g., Gannett v. DePasquale, 443 U.S. 368, 415-33 (1979) (Blackmun, J., dissenting in part), concluding that the sixth amendment gives the public a right to attend criminal trials over the objection of the defendant. Conversely, despite their apparently absolute language, both U.S. Const. art. III, § 2, para. 3 ("The Trial of all Crimes . . . shall be by Jury"), and the eleventh amendment ("The judicial Power . . . shall not be construed to extend to any suit . . . against one of the United States"), have been construed to confer waivable privileges on defendants. Patton v. United States, 281 U.S. 276, 298 (1930) (article III); Clark v. Barnard, 108 U.S. 436, 447 (1883) (eleventh amendment).

ses See 17 U.S. (4 Wheat.) at 239-40 (Mr. Jones).

s68 See id. (invoking the traditional common law antipathy to advance agreements to arbitrate disputes); cf. Atlas Credit Corp. v. Ezrine, 25 N.Y.2d 219, 250 N.E.2d 474, 303 N.Y.S.2d 382 (1969) (holding that a cognovit note waiving personal jurisdiction objections to suit anywhere offended due process); Von Mehren \& Trautman, Jurisdiction to Adjudicate: A Suggested Analysis, 79 HARv. L. REv. 1121, 1138 (1966) ("Consent obtained before the action is brought-indeed, before any dispute has arisen-differs in several ways from consent given after an action has been initiated . . . ."). Recent choice-of-forum decisions have tended to allow advance waivers as well. E.g., The Bremen v. Zapata Off-Shore Co., 407 U.S. 1 (1972) (commercial agreement to litigate in particular court); D.H. Overmyer Co. v. Frick Co., 405 U.S. 174 (1972) (cognovit note in commercial context); National Equipment Rental, Ltd. v. Szukhent, 375 U.S. 311 (1964) (appointment of agent for service of process in particular state). 
"produced a total prostration of the trial by jury, or even involved the defendant in circumstances which rendered that right unavailing for his protection," noting that "cases may be supposed, in which the policy of a country may set bounds to the relinquishment of private rights." "370 Johnson was right not to go too deeply into this vexing problem, and perhaps he had already said too much about it. As he pointed out, the statute allowed the debtor to claim a jury trial at the time of execution, and to require that he assert his right at that time may not have been inconsistent with the right. ${ }^{371}$ Today, however, one might be less likely to agree that the defendant had consented to this limitation, even if it was otherwise acceptable; so far as the report shows, the note he signed revealed only the place of negotiation, not the statutory provision for summary execution..$^{372}$

\section{The Thomas Jefferson}

Apart from diversity cases, the principal head of jurisdiction given to the lower federal courts by the Judiciary Act of 1789 was admiralty. ${ }^{373}$ Maritime cases reaching the Supreme Court were common enough in the early days, and although most of the interesting problems as to the scope of the jurisdiction were to be faced only after Marshall's departure, one of the Court's last pronouncements in this area during his tenure was of considerable though temporary significance.

The ship Thomas Jefferson was libeled for wages earned on a voyage from Kentucky up the Missouri River and back. It took Story but two pages to hold there was no admiralty jurisdiction. The answer was all history and unsupported assertion: "In the great struggles between the courts of common law and the admiralty, the latter never attempted to assert any jurisdiction . . . except in cases where the service was substantially performed ...

37017 U.S. (4 Wheat.) at 243. It was the related statement that the law "must be subjected to a strict construction" because "in derogation of the ordinary principles of private rights," id. at 241-42, that led one admirer of Johnson to the surprising conclusion that the Okely opinion was protective of the right to jury trial. D. Mongan, supra note 13, at 134-35.

${ }^{373} 17$ U.S. (4 Wheat.) at 243. See the statute itself. Id. at 235-37. Cf. Fed. R. Civ. P. 38(b), (d) (requiring a party desiring a jury trial to request it within 10 days after service of the last relevant pleading). But contrast the various decisions culminating in Mitchell v. W.T. Grant Co., 416 U.S. 600 (1974), respecting the validity under the due process clause of pretrial attachment or garnishment of assets.

${ }^{373}$ Cf. Johnson v. Zerbst, 304 U.S. 458, 464 (1938) (defining waiver in the contert of right to criminal defense counsel as "an intentional relinquishment or abandonment of a known right or privilege").

s73 Ch. $20, \S \S 9,11,1$ Stat. 73, 76-77, 78 (current version at 28 U.S.C. $\S 1333$ (1976)). 
upon the sea, or upon waters within the ebb and flow of the tide."

The year was 1825 and the Justice was Story, but this opinion was a reversion to the high-handed style Marshall had employed before 1810. The Court had never before decided the critical question whether admiralty jurisdiction was to be defined according to English precedents; the scattered and poorly explained Supreme Court precedents might have been taken to suggest that it was not. 378 Examination of the purposes of the admiralty clause ${ }^{376}$ might have suggested, as it later would to the Taney Court, that the English definition was too narrow to achieve what the Framers had in mind. ${ }^{377}$ Yet Story did not even bother to state affirmatively his conclusion on this issue, much less to give reasons for it, and we are expected to take his word for what the precedents established without any supporting evidence whatever. ${ }^{378}$

s74 23 U.S. (10 Wheat.) 428,429 (1825).

s75 See The Betsey \& Charlotte, 8 U.S. (4 Cranch) 443, 452 (1808) (holding the place of seizure rather than the place of the offense determined jurisdiction to condemn a vessel); La Vengeance, 3 U.S. (3 Dall.) 297 (1796) (holding maritime an action to condemn a vessel seized for exporting contraband, despite arguments based on British precedents). See also Waring v. Clarke, 46 U.S. (5 How.) 441, 458 (1847) (suggesting an English court would not have upheld maritime jurisdiction in La Vengeance); Currie, supra note 1, at 843-45. I J. KENT, supra note 283, at 376-77, expressed doubt whether La Vengeance "was sufficiently considered," and doubted also whether the jurisdiction included "any thing more than that jurisdiction which was settled and in practice in this country under the English jurisprudence, when the constitution was made . . . ." Justice Washington on circuit, United States v. McGill, 4 U.S. (4 Dall.) 426, 429-30 (C.C.D. Pa. 1806), had said the Constitution "must be taken to refer to the admiralty and maritime jurisdiction of England." Because admiralty cases were not tried by jury, any expansion of admiralty beyond 1791 precedent would arguably have denied a jury in cases where it would have been required when the seventh amendment was adopted. Thus the historical approach the Court was soon to take to the seventh amendment in Parsons v. Bedford, 28 U.S. (3 Pet.) 433 (1830), see supra notes 35862 and accompanying text, furnished a possible additional argument for adhering to historical limits on the admiralty jurisdiction.

s7e U.S. CoNST. art. III, § 2, para. 1.

s77 The Propeller Genesee Chief v. Fitzhugh, 53 U.S. (12 How.) 443 (1852). Hamilton had argued that maritime causes "so generally depend upon the law of nations, and so commonly affect the rights of foreigners, that they fall within the considerations which are relative to the public peace." The Federalist No. 80, supra note 56, at 478 (A. Hamilton). Later Justices have said one purpose of the jurisdiction was to provide the basis for a uniform law governing transportation by water. E.g., Knickerbocker Ice Co. v. Stewart, 253 U.S. 149, 160 (1920). See 3 J. STORY, supra note 109, at 532-33 (mentioning both the interests of "foreigners" and "uniform adjudication," and tying the jurisdiction to "the great interests of navigation and commerce" as well as to "our diplomatic relations and duties to foreign nations").

${ }^{378}$ In declaring that the English admiralty court "never pretended to claim, nor could it rightfully exercise any jurisdiction" except over cases involving services "substantially performed . . . upon waters within the ebb and flow of the tide," 23 U.S. (10 Wheat.) at 427, Story appeared to reject by obiter implication two serious arguments for further limits that 
The denial of jurisdiction in The Thomas Jefferson was all the more striking because Story, above all Justices, had acquired a reputation for an expansive view of the admiralty power. Ten years earlier, sitting on circuit, he had written a scholarly and controversial $^{379}$ opinion asserting jurisdiction over marine insurance, and in doing so he had expressly declared a certain degree of freedom from confining English precedents. ${ }^{380}$ Thus while the opinion was heavy-handed, it can hardly have been result-oriented; Story seems to have bowed to what he viewed as the unfortunate but inevitable limitations of the language. ${ }^{381}$ Indeed, at the end of the opinion he

had been made in earlier cases and that were to be made again: that the English jurisdiction had extended neither to tidewaters within the body of a county nor to transactions consummated only "substantially" at sea. See, e.g., Waring v. Clarke, 46 U.S. (5 How.) 441, 468-69 (1847) (Woodbury, J., dissenting); La Vengeance, 3 U.S. (3 Dall.) 297, 300 (1796) (argument of Mr. Lee). Story himself had exhaustively refuted both arguments 10 years before on circuit. See DeLovio v. Boit, 7 F. Cas. 418 (No. 3776) (C.C.D. Mass. 1815). Possibly all he meant to do in The Thomas Jefferson was to say that not even the broadest claims for English admiralty power would support jurisdiction in the case before him. Nevertheless it is not surprising that, when the Court first squarely faced the question of internal tidewaters, Story's opinion was cited as a precedent for upholding jurisdiction. Waring v. Clarke, 46 U.S. (6 How.) 441, 463 (1847). Moreover, Story had added in The Thomas Jefferson that there was "no doubt that the jurisdiction exists, although the commencement or termination of the voyage may happen to be at some point beyond the reach of the tide." 23 U.S. (10 Wheat.) at 429. Thus he seems to have attempted to resolve by mere fiat at least one controversial issue that was not before him.

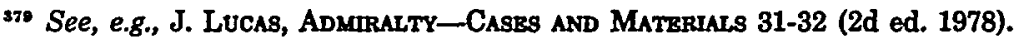

280 DeLovio v. Boit, 7 F. Cas. 418, 441, 443 (No. 3776) (C.C.D. Mass. 1815). See also Note, 37 AM. L. REv. 911, 916 (1903) ("It was said of the late Justice Story, that if a bucket of water were brought into his court with a corn cob floating in it, he would at once extend the admiralty jurisdiction of the United States over it."); Note, From Judicial Grant to Legislative Power: The Admiralty Clause in the Nineteenth Century, 67 Harv. L. Rsv. 1214, 1217 (1954) [hereinafter cited as Harvard Note] (The Thomas Jefferson "stands virtually alone, a curious landmark of admiralty abnegation in a judicial career marked otherwise by determined support of a broadened scope for the American maritime courts."). For lower-court cases before The Thomas Jefferson upholding nontidal jurisdiction, see T. SRRGEANT, supra note 115, at 201-02; Harvard Note, supra, at 1218 n.28. There is some evidence that Marshall thought the case had been wrongly decided. Harvard Note, supra, at 1220 n.47. Story himself, however, wrote in 1835 that there was "nothing in that opinion, which I can, or desire to take back, if I could." Letter from Joseph Story to Joseph Hopkinson (Jan. 3, 1835), quoted in J. McClrllan, Joskph Story aNd the Amaracan Constitution 225 n.68 (1971).

s81 But see 1 E. JHIRAd \& A. SAHN, BENEDict ON AdMIRALTY 7-6 (7th ed. 1981), arguing that the "classical and scriptural equivalents" of the word "maritime"

are applied to all sorts of navigable waters. It is not restricted, even in common speech, to waters where the tide ebbs and flows, for the Baltic Sea, the Black Sea, and the Sea of Azof, the Sea of Marmora, the Mediterranean Sea, the great scenes of early maritime enterprise have no visible tide.

The author of the Harvard Note, supra note 380, at 1218-20, suggests the Court may have trimmed its sails to deflect mounting criticism from Kentucky, noting that three brothers of a powerful Kentucky Senator were part owners of the vessel in question. The Kentucky controversy is also discussed in 1 C. WARREN, supra note 23, at 633-35. But see G. DuNNG, 
went out of his way to suggest a legislative remedy. The Judiciary Act already provided for jurisdiction over seizures on navigable waters above the tide; ${ }^{382}$ whether Congress might not also extend federal jurisdiction to include suits for seamen's wages on such waters "is unnecessary for us to consider." Story thought the constitutional definition of admiralty broader than the identically worded statutory provision then in effect; ${ }^{384}$ he explicitly referred instead to "the power to regulate commerce between the states."38s

This suggestion raises troublesome constitutional questions of its own. Was Story suggesting that a case might arise under federal law within article III even though the only federal "ingredient" of the case was the statute giving jurisdiction? This would seem to be a significant step beyond the expansive Osborn definition. ${ }^{38 B}$ Was he suggesting that the judge-made contract law that would be applied in such a case was a "law of the United States" for jurisdictional purposes? That idea has an interesting later history, ${ }^{\mathbf{9 8 7}}$ but it is hard to square with Story's famous opinion in Swift $v$. Tyson, ${ }^{388}$ in which he held that much judge-made law was not "law" within the statute requiring federal courts in many cases to apply state "laws" as rules of decision. ${ }^{389}$ Was he suggesting that it was not

supra note 259 , at 239 , discounting this view as that of a "cynic" and arguing that "the very historical exegesis which had sustained [Story] in DeLovio explicitly foreclosed an inland jurisdiction which English admiralty never had." This interpretation is not inconsistent with DeLovio's rejection of "English statutes, or decisions of common law founded on those statutes," 7 F. Cas. at 443, for in the same breath Story had equated the American jurisdiction with that "which originally and inherently belonged to the admiralty, before any statutable restriction," id.

ssz Judiciary Act of 1789 , ch. $20, \S 9,1$ Stat. 73,77 (current version at 28 U.S.C. $\$ 1333$ (1976)).

sss 23 U.S. (10 Wheat.) at 430.

sst Story never said whether he was dealing with the statutory or the constitutional question in deciding The Thomas Jefferson, and Marshall had flatly equated statute and Constitution in the diversity context. See Hepburn v. Ellzey, 6 U.S. (2 Cranch) 445 (1805), discussed supra in notes 164-78 and accompanying text.

sss 23 U.S. (10 Wheat.) at 430.

sse See supra notes 299-315 and accompanying text. See also the interesting arguments about "protective jurisdiction" made by HART \& WECHSLER, supra note 41, at 416-17, and rejected by Justice Frankfurter in Textile Workers Union v. Lincoln Mills, 353 U.S. 448, 473-75 (1957) (dissenting opinion).

ssz See Illinois v. City of Milwaukee, 406 U.S. 91, 99-100 (1972) (federal common law a law of the United States within 28 U.S.C. $\$ 1331$ ); Romero v. International Terminal Operating Co., 358 U.S. 354, 359-80 (1959) (general maritime law not within section 1331); Textile Workers Union v. Lincoln Mills, 353 U.S. 448, 456-57 (1957) (statute construed to authorize federal courts to develop common law).

sas 41 U.S. (16 Pet.) 1 (1842).

s89 Judiciary Act of 1789 , ch. $20, \S 34,1$ Stat. 73,92 (current version at 28 U.S.C. § 1652 
necessary to fit the case within article III at all, because the enumeration of cases in that article did not limit the power of Congress to create additional jurisdiction necessary and proper to the exercise of its legislative powers? ${ }^{390}$ Such a position would have contradicted earlier decisions. ${ }^{391}$ Perhaps Story meant only that Congress could create federal question jurisdiction to enforce whatever substantive rights it created by statute under the commerce clause, ${ }^{382}$ for his suggestion followed the conclusion that the existing statute governing the rights and duties of seamen did not extend the jurisdiction. ${ }^{393}$ Yet it was reportedly Story himself who was so moved by the "public inconvenience" caused by his own decision that he dubiously stepped outside the judicial role to draft for Congress a statute extending the jurisdiction to cases arising from shipping on the Great Lakes and their connecting waters-without regard to whether the rights asserted were based on federal statute. ${ }^{394}$ Of course it was appropriate for the Court not to be too specific about what Congress might have power to do in the future; ${ }^{395}$ it might have been more appropriate still to say nothing on the subject at all.

\section{Wayman v. Southard}

A marshal had enforced a federal judgment pursuant to a Kentucky statute regulating the practice of execution; the Supreme Court in 1825 held the state law inapplicable. ${ }^{398}$ The Con-

(1976)).

${ }^{300}$ Cf. National Mut. Ins. Co. v. Tidewater Transfer Co., 337 U.S. 582 (1949) (opinion of Jackson, J., for three Justices).

302 E.g., Hodgson v. Bowerbank, 9 U.S. (5 Cranch) 303 (1809) (no jurisdiction when alien a party unless other party citizen of a state); Mossman v. Higginson, 4 U.S. (4 Dall.) 12 (1800) (same); Hayburn's Case, 2 U.S. (2 Dall.) 409, 410-14 n.(a) (1792) (Justices on circuit refused to carry out statutory duties that were not "judicial"). See Currie, supra note 1, at 851-52. In The Propeller Genesee Chief v. Fitzhugh, 53 U.S. (12 How.) 443, 451-53 (1852), the Court rejected the argument that the commerce clause empowered Congress to extend jurisdiction beyond article III.

302 U.S. ConsT. art. 1, § 8, cl. 3.

39323 U.S. (10 Wheat.) at 430.

39. Act of Feb. 26, 1845, ch. 20, 5 Stat. 726 (current version at 28 U.S.C. $\$ 1333$ (1976)). In deference to the constitutional qualms suggested by the seventh amendment, see supra notes 357-62 and accompanying tert, this statute anomalously provided for jury trial. For Story's part in the drafting of the statute, see Harvard Note, supra note 380 , at $1222 \&$ n.66, and authorities citied therein.

ass Compare the refusal of the Justices to give President Washington an advisory opinion about the legality of belligerent French activities in the United States, discussed in Currie, supra note 1 , at $828-31$.

sec 23 U.S. (10 Wheat.) 1 (1825). 
formity Act adopted only those state laws in force in $1789 ;^{387}$ the Rules of Decision Act required the application of state law only "to guide the court in the formation of its judgment"; 398 and the state had no power to regulate the procedure of the federal courts directly. ${ }^{389}$ Marshall's reasoning on this important constitutional principle consisted of a succession of expletives: it was "one of those political axioms, an attempt to demonstrate which, would be a waste of argument"; the argument "has not been advanced . . . and will, probably, never be advanced"; its "utter inadmissibility will at once present itself to the mind"; it was too "extravagant" to be maintained. ${ }^{400}$ Congress, he had said earlier, ${ }^{401}$ had power to provide for execution under the necessary and proper clause; ${ }^{402}$ he might have argued that this power was implicitly exclusive. In contrast to the question of concurrent state jurisdiction in Houston $v$. Moore, ${ }^{403}$ it does seem unlikely that the states were meant to have any such authority. ${ }^{\text {tot }}$ Marshall's conclusion, despite its lack of supporting reasons, is an important datum to which we shall return in considering the question whether other grants of congressional power should be interpreted as exclusive though they are not expressly made so. ${ }^{403}$

${ }^{397}$ Id. at 32, 41-49. See Act of Sept. 29, 1789, ch. 21, $\S 1,1$ Stat. 93, 93; Act of May 8, 1792 , ch. 36, § 2, 1 Stat. 275, 276. For the current version, see 28 U.S.C. § 1651 (1976).

${ }^{393} 23$ U.S. (10 Wheat.) at 24. See Judiciary Act of 1789, ch. 20, § 34, 1 Stat. 73, 92 (current version at 28 U.S.C. § 1652 (1976)).

39923 U.S. (10 Wheat.) at 49-50.

100 Id. at 49.

10123 U.S. (10 Wheat.) at 22.

${ }^{402}$ U.S. ConST. art. I, § 8, cl. 18. This conclusion does not seem hard to reach, as Congress's authority extends to laws necessary and proper for executing not only its own powers (which include the power to "constitute tribunals inferior to the Supreme Court," U.S. Const. art. I, \& 8, cl. 9), but also "all other Powers vested by this Constitution in the Government of the United States, or in any Department or Officer thereof," U.S. CoNST. art. I, § 8, cl. 18. Nevertheless, anticipating the later decision in Erie R.R. v. Tompkins, 304 U.S. 64 (1938), that the grant of diversity jurisdiction does not empower the courts to create substantive common law, counsel argued in Wayman that it was no more necessary and proper to provide execution rules for diversity cases than to enact a "civil code" for them; in either case state law applied. 23 U.S. (10 Wheat.) at 11-12. For confirmation of the power to regulate diversity procedure after Erie, see Hanna v. Plumer, 380 U.S. 460 (1965). See the suggestion in D. CURRIE, supra note 320 , at 413 , that the distinction can be supported by decisions indicating that a forum disinterested in the merits may have a legitimate stake in the administration of its courts.

${ }^{103}$ See supra notes $336-50$ and accompanying text.

1061 Tucker's Appendix to Blackstone, supra note 86, at 180, had acknowledged in 1803 that Congress's power to establish inferior federal courts was exclusive, and it might be thought to follow that the same was true of regulating their procedures.

${ }^{105}$ See Gibbons v. Ogden, 22 U.S. (9 Wheat.) 1 (1823); Sturges v. Crowninshield, 17 U.S. (4 Wheat.) 122 (1819). 
Of equal significance were the explicit dicta in Wayman upholding provisions of the Conformity Act that authorized the courts to adopt additional rules to govern their own process and procedure. ${ }^{108}$ As applied to matters such as the definition of property to be seized, it was argued that these provisions constituted "a delegation of legislative authority which congress . . . has not the power to make."407 This was the second time this interesting proposition had been argued to the Supreme Court, ${ }^{408}$ and this time the Court conceded, without saying why, that Congress could not delegate to the courts or to other tribunals "powers which are strictly and exclusively legislative." 409 Nevertheless, and again without giving reasons, Marshall concluded that no clear line separated legislative from other powers: "[C]ongress may certainly delegate to others, powers which the legislative may rightfully exercise itself"- such as "the mere regulation of practice in the court." ${ }^{410}$ Thus, as in The Aurora, ${ }^{411}$ where Johnson had flatly held that an embargo law could be made conditional on a presidential finding that Britain or France was no longer violating our neutrality, ${ }^{412}$ Marshall laid down constitutional principles of first importance as a matter of mere fiat. ${ }^{418}$ Nor in Wayman did he bother

${ }^{108}$ Act of May 8, 1792, ch. 36, $\S 2,1$ Stat. 275, 276 (current version at 28 U.S.C. $\S \S$ 2071-2072 (1976)).

${ }^{107} 23$ U.S. (10 Wheat.) at 15-16 (argument for the defendants); id. at 42 (opinion of Marshall, C.J.) (quoted in text).

${ }^{08}$ See The Aurora, 11 U.S. (7 Cranch) 382, 386 (1813).

${ }^{402} 23$ U.S. (10 Wheat.) at 42. The most convincing reasons would be that the Constitution vests all its granted "legislative Powers" in Congress, U.S. ConsT. art. I, § 1, see 23 U.S. (10 Wheat.) at 13 (argument of defendants), and that the courts are given only "judicial Power," U.S. Const. art. III, § 1. On the first argument, see, e.g., Schechter Poultry Corp. v. United States, 295 U.S. 495 (1935); on the second, see Hayburn's Case, 2 U.S. (2 Dall.) 409, 410-14 n.(a) (C.C.D.N.Y. \& C.C.D. Pa. 1792), and the Correspondence of the Justices, supra note 41 .

41023 U.S. (10 Wheat.) at $42-43$.

1111 U.S. (7 Cranch) 382 (1813).

412 Id. at 388 ("[W]e can see no sufficient reason, why the legislature should not exercise its discretion in reviving the act of March 1st, 1809, either expressly or conditionally, as their judgment should direct.").

13 Marshall could have avoided the broad conclusion that some legislative power could be delegated by finding that the judicial authority to try cases carried with it the power to determine how they should be tried. He had made such a suggestion with respect to the contempt power in $E x$ parte Bollman, 8 U.S. (4 Cranch) 75, 94 (1807) (dictum); cf. Anderson v. Dunn, 19 U.S. (6 Wheat.) 204 (1821) (upholding the implicit power of the House of Representatives to punish contempts by nonmembers). Possibly that is what was meant by Marshall's statement in Wayman that "[a] general superintendence of this subject seems to be properly within the judicial province," 23 U.S. (10 Wheat.) at 45 , but that would have been a significant decision too.

Again without relying on precedent or argument, Marshall suggested criteria relevant to drawing the line between permissible and impermissible delegations, a problem that contin- 
citing The Aurora; moreover, because the question in the case was the applicability of state law, the power of the court to make its own rule was not in issue at all. ${ }^{414}$

\section{E. American Insurance Co. v. Canter}

Bales of cotton salvaged from a shipwreck had been purchased at a judicial sale ordered by a court established by the legislature of the Territory of Florida. A federal district court held the Florida decree invalid; the circuit court disagreed; and the Supreme Court, in an 1828 Marshall opinion, upheld the circuit court. ${ }^{415}$

The constitutional objection to the Florida judgment was that the case was within the admiralty jurisdiction vested by article III in the Supreme Court and in "such inferior Courts as the Congress may . . . ordain and establish,"416 and therefore that it could be decided only by a court created by Congress. ${ }^{117}$ Arguments in support of the jurisdiction included the contention that Congress had delegated its power to the territorial legislature; ${ }^{\mathbf{1 1 8}}$ opposing counsel responded that "delegatus non potest delegare"119_another foretaste of controversies to come. ${ }^{420}$ It was also suggested that the entire Constitution was inapplicable in Florida ${ }^{421}$ a self-defeating argument that would appear to destroy the basis on which the territorial court had been established. ${ }^{.22}$

ued to vex the Court for a great many years:

The line has not been exactly drawn which separates those important subjects, which must be entirely regulated by the legislature itself, from those of less interest, in which a general provision may be made, and power given to those who are to act under such general provisions, to fill up the details.

Id. at 43.

${ }^{414}$ Marshall said as much himself, 23 U.S. (10 Wheat.) at 48; he was discussing the question in answer to the argument that Congress must have meant for new state laws to apply because otherwise federal courts in the newer states would be without an execution law, id. at 17.

41826 U.S. (1 Pet.) 511 (1828).

416 U.S. Const. art. III, $\S 1$.

1126 U.S. (1 Pet.) at 529 (Mr. Ogden).

418 Id. at 534-35 (Mr. Whipple).

120 Id. at 540 (Mr. Ogden).

420 See, e.g., Schechter Poultry Co. v. United States, 295 U.S. 495 (1935). See also supra notes 406-14 and accompanying text (discussing Wayman v. Southard and The Aurora).

42126 U.S. (1 Pet.) at 533 (Mr. Whipple); id. at 538 (Mr. Webster).

422 In the debate over a provisional government for the Louisiana Territory, the Jeffersonians had argued for an inherent power to acquire and govern territory wholly without reference to the Constitution. See $2 \mathrm{H}$. Adams, History or the United States During the Administrations of JeFrerson and Madison 94-134 (1889). Webster seems to have embraced this position in his argument in Canter, 26 U.S. (1 Pet.) at 538, but Whipple's argu- 
Marshall's response was that article III did not limit the powers of the territorial courts because they had not been created under article III. "They are legislative courts, created in virtue of the general right of sovereignty which exists in the government, or in virtue of that clause which enables congress to make all needful rules and regulations, respecting the territory belonging to the United States." 423 The ambiguity of this passage as to the source of congressional authority over the territories was to haunt the Court in the Dred Scott case thirty years later. ${ }^{424}$ For present purposes the significance of Marshall's opinion lies in his conclusion that jurisdiction of article III cases could be vested in tribunals not established in accordance with that article. Indeed, Marshall viewed the fact that the territorial judges did not hold their offices during "good Behaviour" as a factor supporting the constitutionality of their jurisdiction: article III did not apply because the judges had only four-year terms. ${ }^{426}$

But why was it that the Constitution vested the judicial power in courts whose judges enjoyed life tenure and irreducible salary? Hamilton made clear in The Federalist that this was a means of assuring the judiciary's independence: "That inflexible and uniform adherence to the rights of the Constitution, and of individuals, which we perceive to be indispensable in the courts of justice, can certainly not be expected from Judges who hold their offices by a temporary commission." ${ }^{26}$ The Pennsylvania circuit court had

ment based the power to govern Florida on the Constitution, id. at 533.

42326 U.S. (1 Pet.) at 546. The clause in question appears in U.S. ConsT. art. IV, \& 3 , para. 3 ("The Congress shall have Power to dispose of and Make all needful Rules and Regulations respecting the Territory or other Property belonging to the United States ....").

Earlier in the opinion Marshall had disposed by ipse dixit of the great constitutional question that had prompted Jefferson to agitate vainly for a constitutional amendment before buying Louisiana (see $2 \mathrm{H}$. ADAMs, supra note 422, at 74-93): "The constitution confers absolutely on the government of the Union, the powers of making war, and of making treaties; consequently, that government possesses the power of acquiring territory, either by conquest or by treaty." 26 U.S. ( 1 Pet.) at 542. Because no litigant had challenged the power to acquire Florida, there was no need to say anything on the subject.

s24 Scott v. Sandford, 60 U.S. (19 How.) 393 (1857). See also 1 C. WARREN, supra note 23, at 700 (Canter "became the foundation of much of the discussion, thirty years later, in the debates on the power of Congress over slavery in the Territories"). Justice Johnson, in the circuit court opinion in Canter, had explicitly denied the applicability of article IV to territory acquired by cession, finding the power to acquire and govern territory "incidental to the treaty-making power, and perhaps to the power of admitting new states into the Union." 26 U.S. (1 Pet.) at 519 n.(a).

128 26 U.S. (1 Pet.) at 546.

428 The Federalist No. 78, supra note 56, at 470-71 (A. Hamilton). See also 3 J. Story, supra note 109, at 457-97 (quoting and expanding on The Federalist); 1 Tucker's Appendix 
reached the same conclusion in refusing to carry out the pension law in Hayburn's Case because the law subjected the court's decision to executive revision; ${ }^{427}$ the North Carolina circuit in the same instance had concluded that the law was unconstitutional because it gave judicial power to the Secretary of War. ${ }^{428}$ The tenure and salary provisions of article III can accomplish their evident purpose only if they are read to forbid the vesting of the functions within its purview in persons not enjoying those protections. Marshall cannot have been right that the violation of article III is its own justification. ${ }^{\text {29 }}$

In any event, Marshall drew back from the extreme implications of his argument: "Although admiralty jurisdiction can be exercised in the states, in those courts only which are established in pursuance of the third article of the constitution; the same limitation does not extend to the territories."430 Thus he acknowledged in general the negative implication of article III, but found this limitation inapplicable to the power to govern the territories.431

to Blackstone, supra note 86 , at 268 (praising the good-behavior requirement as placing judges "beyond the reach of hope or fear, where they might hold the balance of justice steadily in their hands").

4272 U.S. (2 Dall.) 409, 411-12 n.(a) (1792).

428 Id. at 413:

[F]or though congress may certainly establish . . . courts of appellate jurisdiction, yet such courts must consist of judges appointed in the manner the constitution requires, and holding their offices by no other tenure than that of their good behavior, by which tenure the office of secretary at war is not held.

120 Justice Washington had already said in Houston v. Moore, 18 U.S. (5 Wheat.) 1, 25 26 (1820), that article III cases could be decided in state courts unless Congress otherwise provided, though Justice Johnson's peculiar opinion in Ogden v. Saunders, 25 U.S. (12 Wheat.) 213, 271 (1827), and some dicta of Story's about admiralty itself, see supra note 342, pointed the other way. Marshall might have cited the power of state courts over article III cases, as Brandeis was later to do in Crowell v. Benson, 285 U.S. 22, 86-87 \& n.22 (1932) (dissenting opinion), as precedent that jurisdiction over such cases was not limited to article III courts. But The Federalist saw no inconsistency in arguing both that state courts could decide article III cases, The Federalist No. 82, supra note 56, at 492-93 (A. Hamilton), and that federal judges must have tenure, id. No. 78, at 469-72 (A. Hamilton). There are obvious grounds for deference to state interests that distinguish state courts from federal courts outside article III, and state courts, whatever their weaknesses, at least are independent of the President and of Congress. See Krattenmaker, Article III and Judicial Independence: Why the New Bankruptcy Courts are Unconstitutional, 70 Gzo. L.J. 297, 304 (1981) (arguing that the central concern of the tenure and salary requirements was "the separation of powers at the federal level") (emphasis in original).

43026 U.S. (1 Pet.) at 456. Story, who had gone along in Canter despite his firm attachment to the tenure provisions, see supra note 426, explained in his treatise that territorial courts were a special case. $3 \mathrm{~J}$. STORY, supra note 109, at 498-99.

131 United States v. More, 7 U.S. (3 Cranch) 159 (1805), had presented the same question in the context of the District of Columbia, and the Court had not decided it. The lower court decision in More, which Marshall did not cite, held the salary provision of article III 
Canter, as we have seen, was not the first case to raise the question of the constitutional status of those peculiar American areas that are not states, ${ }^{\mathbf{4 3 2}}$ yet Marshall referred to no prior decisions. Nor did he give any reason worthy of the name for his essentially bald conclusion; from his irreproachable statement that in legislating for a territory Congress has both general and local powers ${ }^{\text {tss }}$ it does not follow that the Framers were unconcerned about the independence of territorial judges. ${ }^{484}$

Thus even as to the territories themselves, the poorly explained Canter holding is difficult to reconcile with the purposes of article III. Moreover, despite its express disclaimer, the opinion has since been taken as authority for vesting powers over certain article III cases within the states in federal officers who do not enjoy the independence that article provides. ${ }^{435}$ The first small step down the road to perdition may prove to be irreversible.

\section{F. Cherokee Nation v. Georgia}

The Cherokee Nation sued in the Supreme Court to enjoin the state from enforcing Georgia law within the territory reserved to the Cherokees by treaty. Jurisdiction was denied in 1831.436 The Cherokees lived within the boundaries of the United States and their rights were subject to congressional restriction; the separate treatment of "foreign nations" and "Indian tribes" in the commerce clause ${ }^{437}$ confirmed the conclusion that, although the Cher-

applicable within the District. United States v. More, reprinted in 7 U.S. (3 Cranch) at 160 n.(b) (inserted by Judge Cranch).

132 See supra notes $164-78$ and accompanying text.

13s 26 U.S. (1 Pet.) at 546.

4s4 See C. WRIGHT, supra note 46, at 31, 37 (terming Canter "a doctrine of doubtful soundness": "If judicial independence is of vital importance in the states, it is hard to see why it is not equally valuable in territories."). The latter-day rationalization that the Framers could not have intended to leave the country with a flock of judges with nothing to do but collect their salaries after a territory became a state, see O'Donoghue v. United States, 289 U.S. 516, 536-38 (1933), had to be abandoned when the Canter doctrine was extended to the District of Columbia, which was not meant to be transitory. See Palmore v. United States, 411 U.S. 389, 405-07 (1973). Moreover, this was a dangerous argument, because the reference to "such inferior Courts as the Congress may from time to time ordain and establish," U.S. CoNST. art. III, § 1 (emphasis added), suggests that any grant of jurisdiction may be temporary -as was amply demonstrated by the repeal of the Judiciary Act of 1801. See supra notes 102-03 and accompanying text.

${ }^{435}$ See Ex parte Bakelite Corp., 279 U.S. 438, 448-51 (1929) (Court of Customs Appeals).

136 30 U.S. (5 Pet.) 1, 29-30 (1831). The background of the litigation, including the execution of a Cherokee in defiance of a Supreme Court stay, see id. at 12-13, is discussed in 4

A. BEVERIDGB, supra note 11, at 539-46, and 1 C. WARREN, supra note 23, at 729-79.

${ }^{437}$ U.S. ConsT. art. I, $\$ 8$, cl. 3 (granting Congress power "[t]o regulate Commerce with 
okees were a "State," they were not a "foreign State" within the article III provision extending the judicial power to controversies between "a State . . . and foreign states." 438

This reasoning harks back to Hepburn v. Ellzey, ${ }^{439}$ where Marshall had used a similar analogy to show the District of Columbia was not a "state" within article III."10 This time he acknowledged that "the same words have not necessarily the same meaning ... in different parts of the same instrument," but he found "nothing in the context, and nothing in the subject of the article," to suggest "an intention to desert" the "former meaning" of the term "foreign state." 4 14 $\mathrm{He}$ did not refer to the purpose of the clause, which might have cut against him. ${ }^{442}$

This resolution made it unnecessary to decide whether Georgia was immune to suit by an Indian tribe, and Marshall said nothing on that subject. Thompson, joined in dissent by Story, said there was no immunity because the suit was outside the terms of the eleventh amendment. ${ }^{43}$ The latter statement was true enough, but later cases would show it was not a complete answer, ${ }^{444}$ and Thompson did not bother to invoke the authority of Chisholm $v$. Georgia. ${ }^{405}$

foreign Nations, and among the several States, and with the Indian Tribes").

$4 s 30$ U.S. (5 Pet.) at 16-20 (construing U.S. ConsT. art. III, $\S 2$, para. 1). Johnson, concurring, also doubted the Cherokees were a "State" at all, because "[ $t$ ]hey never have been recognized as holding sovereignty over the territory they occupy." 30 U.S. (5 Pet.) at 22.

4s9 6 U.S. (2 Cranch) 445 (1805).

110 See supra notes 164-78. and accompanying text.

1430 U.S. (5 Pet.) at 19-20. Thompson suggested in dissent that Indians had been specially mentioned in the commerce clause to counteract any negative inference that might otherwise have arisen from the separate powers of Congress respecting Indians in article 9 of the Articles of Confederation. Id. at 63-64. Moreover, he argued, the executive in negotiating treaties with Indian nations had consistently regarded them as "foreign." Id. at 59-62.

${ }^{442}$ See, e.g., Chisholm v. Georgia, 2 U.S. (2 Dall.) 419, 467 (1792) (separate opinion of Cushing, J.) ("for preventing controversies between foreign powers or citizens from rising to extremities and to an appeal to the sword, a national tribunal was necessary"); THE FEDERALIST No. 80, supra note 56, at 475-76 (A. Hamilton) (assimilating controversies involving foreign states to "those which involve the PEACE of the CONFEDERACY" and arguing that "the peace of the WHOLE ought not be left at the disposal of a PART"). For a thoughtfully reasoned contemporaneous criticism of the opinion on this and other grounds, see Everett, The Cherokee Case, 33 N. Am. L. Rev. 136, 142-50 (1831).

1130 U.S. (5 Pet.) at 52.

114 E.g., Monaco v. Mississippi, 292 U.S. 313 (1934) (foreign state cannot sue unconsenting state); Hans v. Louisiana, 134 U.S. 1 (1890) (citizen cannot bring federal question case against his own state without consent).

${ }^{415} 2$ U.S. (2 Dall.) 419 (1793) (holding, before adoption of the eleventh amendment, that one state could be sued by a citizen of another). See Currie, supra note 1, at 831-39. In the same Term in which Cherokee was decided, the Court upheld its jurisdiction in a suit by one state against another without discussing immunity. New Jersey v. New York, 30 U.S. (5 
Marshall suggested an additional difficulty which he found unnecessary to resolve:

The bill requires us to control the legislature of Georgia, and to restrain the exertion of its physical force. The propriety of such an interposition by the court may be well questioned; it savors too much of the exercise of political power, to be within the proper province of the judicial department.46

Indeed as to some matters, such as "the laws making it criminal [for the Cherokees] to exercise the usual power of self-government in their own country," Marshall squarely said "this court cannot interpose; at least, in the form in which those matters are presented."447 Just what Marshall meant by these passages is less than clear; obviously they lend some support to the later political question doctrine. ${ }^{48}$ It does seem, however, that Marshall did not mean the question of Georgia's legislative jurisdiction over the reservation was inherently nonjusticiable, for the next year the Court was to resolve that very question in Worcester $v$. Georgia. ${ }^{40}$ If one has a legitimate complaint about Marshall's cryptic comments about "political" issues, it is that he once again felt called upon to discuss an issue not properly before him. Johnson, who made the "political" nature of the claim an alternative ground of his concurrence, ${ }^{400}$ was even more willing to decide the larger question. ${ }^{\mathbf{5 1}}$

Johnson's concurrence, together with the two dissents and another concurring opinion by Baldwin, ${ }^{462}$ left Marshall speaking in

Pet.) 283 (1831).

40 U.S. (5 Pet.) at 20.

467 Id.

"s See Baker v. Carr, 369 U.S. 186, 208-37 (1962). Marshall did not cite in Cherokee his earlier reference to "political" issues in Marbury v. Madison, 5 U.S. (1 Cranch) 137, 165-67, 169-71 (1803). See supra note 45.

41 31 U.S. (6 Pet.) 515 (1832). Maybe Marshall was talking of limits on the traditional equity jurisdiction; maybe he was foreshadowing the limited view of state standing taken in Massachusetts v. Mellon, 262 U.S. 447 (1923); maybe he was relying implicitly on article III's "Case" or "Controversy" language or its reference to the "judicial" power.

${ }^{460} 30$ U.S. (5 Pet.) at 28-29. Even Thompson in dissent, id. at 75, conceded the Court should not enforce all treaty rights or exercise "political power." He insisted, however, that the Cherokees claimed invasions of "rights of person or property" that equity could protect-such as the seizure of their mines and the threatened survey and redistribution of their lands. Id. at 75-77.

"61 This, as we shall see, was characteristic of Johnson. Cf. Gibbons v. Ogden, 22 U.S. (9 Wheat.) 1 (1823); Fletcher v. Peck, 10 U.S. (16 Cranch) 87 (1810).

${ }^{43}$ Justice Henry Baldwin, whom we here meet for the first time, was an 1830 Jackson appointee who belongs chiefly to the Taney period. In Cherokee he concurred "in the opinion of the Court, . . . but not for the reasons assigned." 30 U.S. (5 Pet.) at 31. He stressed the history of our Indian relations, drew inferences not only from the commerce clause but 
the strict sense for only three of the seven members of the Court; the reporter's statement that the Chief Justice "delivered the opinion of the court" must be taken subject to qualification.

\section{CoNCLUSION}

With the Cherokee Nation case in 1831 we approach the end of an era. Only four of the seven Justices who had constituted the Marshall Court for so many years remained. Two of the newcomers, Thompson and Baldwin, were striking out on their own, while both Johnson and Story, the most assertive of the old-timers, also expressed independent views. Marshall's iron grip, as other contemporaneous cases will confirm, was loosening; Cherokee was a long way from both the brief and unanimous Marshall pronouncements of the first decade and from the grandiloquent and largely unchallenged essays of the period around 1820, when Marshall's power was at its height. In another four years Johnson and Duvall, as well as Marshall, would be gone, leaving only Story of the central seven; a nine-member Court with seven Jackson and Van Buren appointees would be sitting by 1837.453

The most striking feature of the Court's decisions respecting the federal courts until almost the end of Marshall's tenure was the rarity of expressed differences of opinion. Johnson was the most likely to dissent ${ }^{454}$ or to concur specially, ${ }^{455}$ and at the end he went so far as to say it was his "practice" to give his own opinion "on all constitutional questions."4s8 Though sometimes less favorable to federal jurisdiction than Marshall, ${ }^{457}$ even Johnson

also from article I's apportionment of representatives and direct taxes according to population "excluding Indians not taxed," U.S. CoNST. art. I, \& 2, para. 3, and lectured his dissenting colleagues as to the "sacrilege" of departing from the "plain" terms of the Constitution "according to any fancied use, object, purpose or motive, which, by an ingenious train of reasoning I might bring my mind to believe was the reason for its adoption." 30 U.S. (5 Pet.) at 41-43. "We can thus expound the constitution," he said snappishly, "without a reference to the definitions of a state or nation by any foreign writer, hypothetical reasoning, or the dissertations of the Federalist." Id. at 40-41.

453 See G. GunTHER, supra note 26 , app. A, at A-2, A-3. The eighth and ninth positions were created by the Act of March 3, 1837, ch. 32, § 1, 5 Stat. 176, 176 (current version at 28 U.S.C. \& 1 (1976)).

4S6 See supra notes 145-59, 299-323, 324-35, and accompanying text, and supra note 319 (discussing Ex parte Bollman, Osborn v. Bank of the United States, Bank of the United States v. Planters' Bank, and Governor of Georgia v. Madrazo).

${ }_{455}$ See supra notes 223-59, 336-53, 436-52, and accompanying text (discussing Martin v. Hunter's Lessee, Houston v. Moore, and Cherokee Nation v. Georgia).

4s8 Cherokee Nation v. Georgia, 30 U.S. (5 Pet.) 1, 21 (1831).

657 In three of the four cases cited supra in note 455, Johnson dissented from the upholding of jurisdiction; in Madrazo, however, he dissented from its denial. 
usually went along, most notably with the crucial decisions in Martin v. Hunter's Lessee and Cohens $v$. Virginia, and his concurring opinion in the former case indicates he did so there out of conviction, not from a mere respect for the principle of unanimity. Story was more nationalistic than the Court in Houston and in Chero$k e e$, and in the latter case Thompson was with him. Apart from these, Baldwin's concurrence in Cherokee, and Story's unidentified compatriot in Houston, no Justice uttered a divergent word in any of the cases considered in this study.

The overwhelming preponderance of opinions for the Court in this field during this period, moreover, bore the name of Marshall. Story spoke for the Court in Martin, and Paterson in Stuart $v$. Laird, where the Chief Justice could not participate; Story was also the spokesman in the much later cases of The Thomas Jefferson and Parsons $v$. Bedford. Johnson wrote for the Court in Bank of Columbia v. Okely, and Washington spoke for himself in Houston, where there was no majority opinion. The other eight Justices-Cushing, Chase, Moore, Livingston, Todd, Duvall, Trimble, and McLean-were not heard from at all.

In terms of results, the Court in the Marshall years was friendly toward the powers of federal courts but, with the possible exception of the sovereign immunity cases involving the national bank, not immoderately so. ${ }^{488}$ Both the diversity and admiralty powers were construed with what later cases have shown to be considerable restraint, ${ }^{458}$ as was the original jurisdiction in Cherokee; concurrent state authority even over criminal cases was recognized in Washington's opinion in Houston $v$. Moore. The most memorable cases, Marbury and Martin, which established the Court's effective power to determine the constitutionality of federal and state legislation, merely confirmed what seems to have been understood at the Philadelphia Convention.

With regard to the crafting of opinions, we have inconsistent glimpses of Story, careful and convincing in Martin and conclusory in The Thomas Jefferson. Johnson was strong in his use of precedent in Planters' Bank, confused in Osborn and in Bank of Columbia $v$. Okely, and eager to decide more than was necessary in Cherokee. The rest is almost all Marshall: rhetorical flourish, bare assertion, plentiful dicta, multiple holdings, inattention to

4s8 See G. HASkins \& H. Johnson, supra note 24, at 399 ("Self-restraint and extreme caution in asserting jurisdiction characterized the Supreme Court from 1801 to 1815 .....").

6so See supra notes $37-38$ and accompanying text. 
favorable precedent, and emphasis on the undesirable consequences of an interpretation at variance with his own. We shall see these same characteristics confirmed in the Court's contemporaneous decisions respecting the powers of Congress and of the states, which are the subject of the next article in this series. 